\title{
Chemoenzymatic Syntheses of Some Analogues of the Tricarbocyclic Core of the Anti-bacterial Agent Platencin and the Biological Evaluation of Certain of Their $N$-Arylpropionamide Derivatives*
}

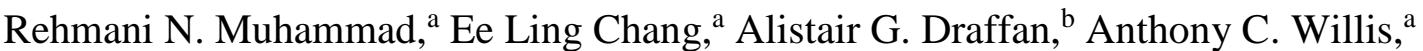 \\ Paul D. Carr ${ }^{\mathrm{a}}$ and Martin G. Banwell ${ }^{\mathrm{a}, *}$
}

${ }^{a}$ Research School of Chemistry, Institute of Advanced Studies,
The Australian National University, Canberra, ACT 2601

and

${ }^{\text {b} B i o t a ~ S c i e n t i f i c ~ M a n a g e m e n t ~ P t y ~ L t d, ~ M e l b o u r n e, ~ V I C ~} 3168$

\begin{abstract}
A range of structural variations on the tricarbocyclic core, 2, of the anti-bacterial agent platencin (1), including those represented by compounds 14, 15 and 27, have been prepared and certain of these elaborated, through substrate-controlled enolate alkylation reactions, to analogues of the natural product. Preliminary biological evaluation of these analogues revealed that they are only weakly active anti-infective agents.
\end{abstract}

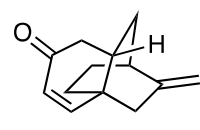

2

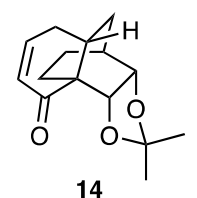

14

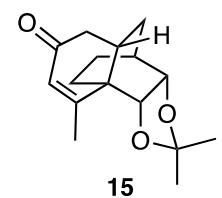

15

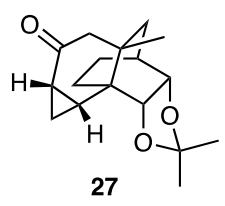

27

* Dedicated to the memory of Professor Sir Derek Barton and in recognition of his seminal contributions to so many aspects of organic chemistry 


\section{Introduction}

The development of drug-resistant bacteria has been described as one of the most significant threats facing humankind at the present time. ${ }^{1}$ In seeking to address this profound challenge through the identification of new anti-bacterial agents possessing novel modes of action, scientists at Merck \& Co. isolated platencin (1) from a strain of the soil bacterium Streptomyces platensis. ${ }^{2}$ It was established that this natural product inhibited certain enzymes associated with bacterial fatty acid biosynthesis and thus interfering with the assembly of their cell walls. ${ }^{2}$ As a result, compound $\mathbf{1}$ acts against a wide range of bacteria including methicillin-resistant Staphylococcus aureus (MRSA), vancomycin-resistant enterococci (VRE) and Mycobacterium tuberculosis. Such features, together with its lack of toxicity to mammalian systems, have created significant interest in platencin as a lead for the development of new generation anti-bacterial agents. ${ }^{2,3}$ Accordingly, extensive efforts have been directed toward its synthesis and a range of approaches has been reported and reviewed. ${ }^{1,4}$

In 2008 we detailed ${ }^{5}$ an enantioselective synthesis of compound 2 that embodies the tricarbocyclic core of platencin and that has been elaborated, by Nicolaou and-coworkers, ${ }^{6}$ to platencin itself. The starting material used in our work was the cis-1,2-dihydrocatechol 3. This is obtained in homochiral form through the whole-cell biotransformation of iodobenzene using the genetically engineered micro-organism E. coli JM109 (pDTG601) that overexpresses the responsible enzyme, namely toluene dioxygenase. ${ }^{7}$

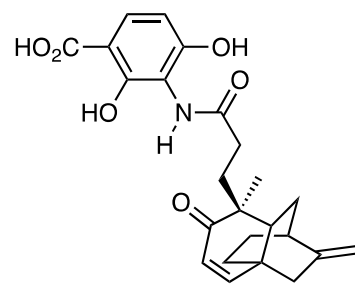

1

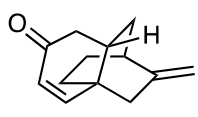

2

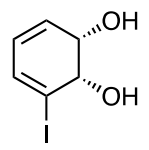

3

The key features of our reaction sequence ${ }^{5}$ leading to enone $\mathbf{2}$ are shown in Scheme 1. Thus, the readily obtained acetonide derivative, $\mathbf{4}$, of diol $\mathbf{3}$, was subjected to a Negishi-type crosscoupling with the racemic organozinc species 5 and so forming the triene 6 as a ca. 1:1 
mixture of diastereoisomers in 85\% combined yield. Despite the absence of an activating group, the side-chain double bond within compound $\mathbf{6}$ engaged in a remarkably facile, thermally-induced and diastereoselective Type 1 intramolecular Diels-Alder (IMDA) cycloaddition reaction with the diene moiety embedded in the cis-1,2-dihydrocatechol residue and thus affording adduct 7 in $89 \%$ yield. A series of twelve relatively conventional functional group interconversions then allowed for the completion of the synthesis of compound 2.

\section{Scheme 1}
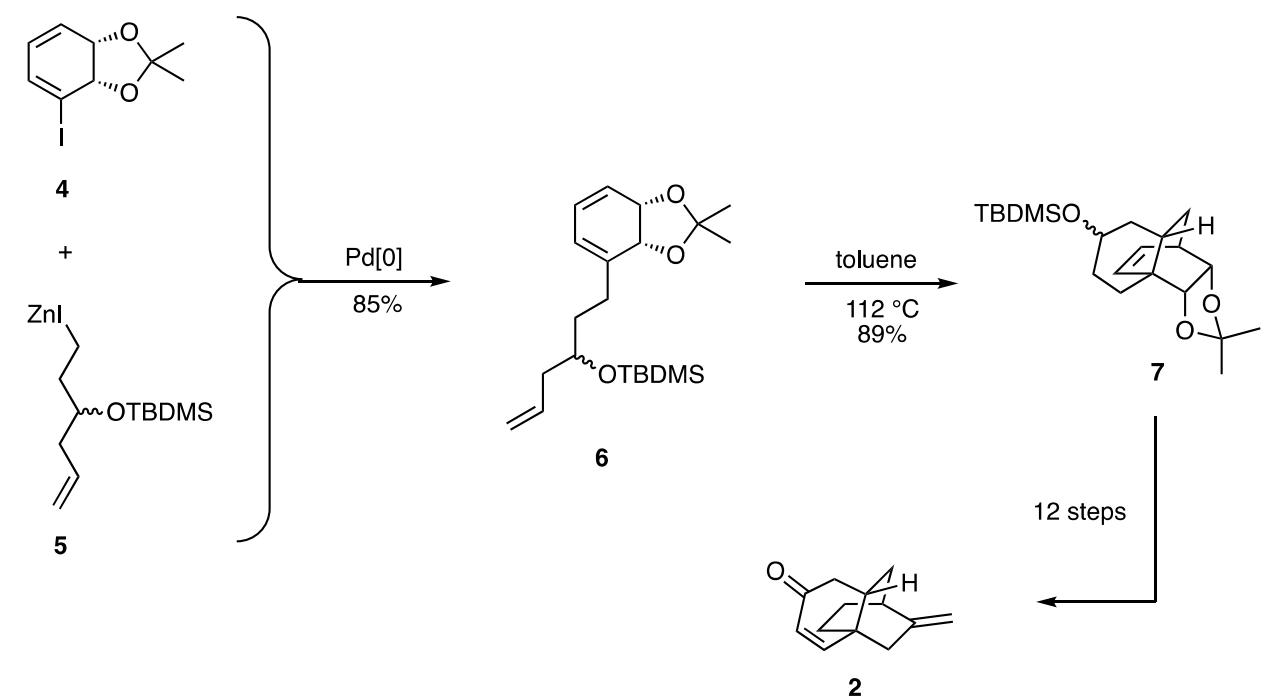

In an effort to establish a shorter route to platencin the pathway shown in Scheme 2 was developed. ${ }^{8}$ Thus, acetonide 4 was now engaged in a Stille cross-coupling reaction with a more elaborate side-chain, namely the Z-configured alkenylstannane 8 and wherein the associated stereogenic center was constructed using a chiral auxiliary-based approach. While the tetra-ene 9 (80\%) so-formed failed to engage in the hoped-for IMDA cycloaddition reaction, the readily derived ketone 10 (53\%) did so and thus producing adduct 11 in 79\% yield. The differing behaviors of compounds $\mathbf{9}$ and $\mathbf{1 0}$ towards this critical cycloaddition process may reflect the conformational preferences within the latter substrate that predispose it, through pre-organizational effects, toward reaction. Adduct $\mathbf{1 1}$ could be elaborated to platencin over 13-steps, although on exposing this compound to hydrogen in the presence of 
Pd on C not only did cleavage of the benzyl ether and hydrogenation of the isolated C-C double bond take place (both desired processes) but the double-bond of the enone moiety was also reduced (an undesired process). As a result, two additional steps were required to reinstate the latter bond.

\section{Scheme 2}

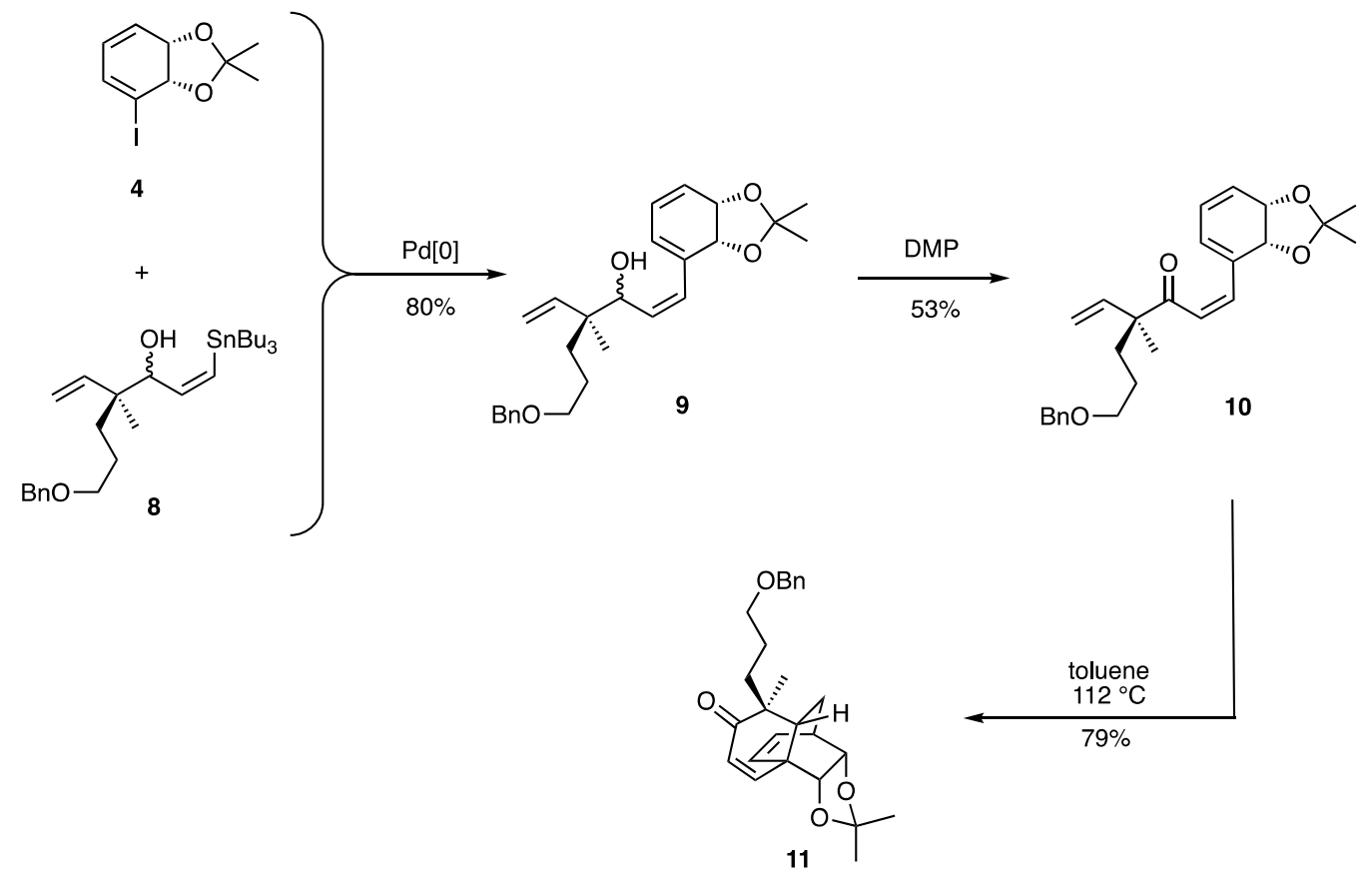

In another study, the outcomes of which we reported recently, ${ }^{9}$ compound 2 was elaborated, including via substrate-controlled enolate alkylation reactions, into platencin (1) and by a slightly shorter route than that involving the manipulation of the IMDA adduct $\mathbf{1 1 .}$

In an effort to improve the pharmacokinetic properties of platencin, considerable effort has been directed toward the synthesis of analogues. ${ }^{2 b}$ Structure activity relationship studies in this domain have revealed that modest variations in the tricarbocyclic core, 2, of platencin can be tolerated but that even minor modifications to the 3-amino-2,4-dihydroxybenzoic acid residue are deleterious. The impact of varying the nature of the propionamide linker between these two motifs remains to be established. 
In this report we now detail efforts to apply the "intelligence" gathered during the abovementioned total synthesis studies on compound $\mathbf{1}$ to the production of various analogues of the tricarbocyclic core of the natural product as well as the elaboration of certain of these to "fully fledged" variants of platencin for the purposes of subjecting them to biological evaluation. Amongst the various analogues of enone 2 targeted in preliminary synthetic studies were compounds 12-15. These were sought because of their anticipated ease of access using our established chemical protocols and the lack of any prior studies on most of them. The approaches to these compounds are detailed in the following section, as are the outcomes of studies on the conversion of certain of these into $\mathrm{N}$-arylpropionamide derivatives for the purposes of assessing their anti-bacterial effects.
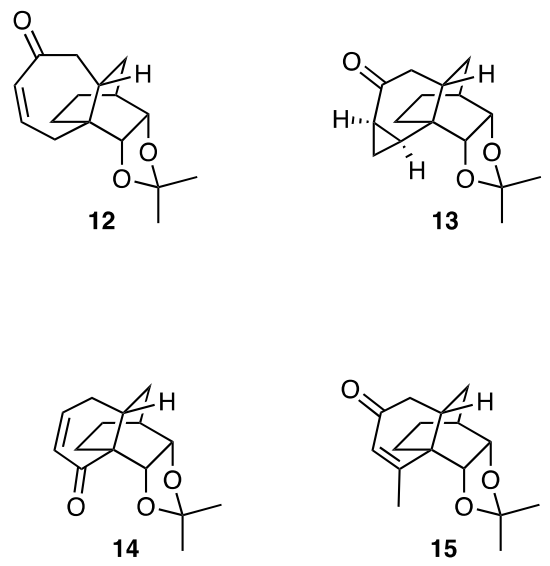

\section{Results and Discussion}

\section{Synthetic Studies}

The approach taken in efforts to prepare our initial target compound $\mathbf{1 2}$ is shown in Scheme 3 and involved attempting to implement an IMDA reaction analogous to that employed in obtaining compound $\mathbf{2}$ (Scheme 1). Thus, the previously reported ${ }^{5}$ diene $\mathbf{1 6}$ was subjected to mono-hydroboration using 9-borabicyclo[3.3.1]nonane (9-BBN) and the ensuing organoborane oxidized in situ to give, in racemic form, the $1^{\circ}$-alcohol $\mathbf{1 7 ^ { 1 0 }}$ in $75 \%$ yield. The reaction of compound $\mathbf{1 7}$ with triphenylphosphine in the presence of molecular iodine gave the anticipated Appel-type product 18 (79\%) and the organozinc species derived from this was cross-coupled with the iododiene 4 to give the triene 19 (65\%) as a ca. 1:1 mixture of diasteroisomers. Treatment of this last compound with tetra-n-butylammonium fluoride 
(TBAF) then afforded the corresponding alcohol 20. Disappointingly, and despite examining a range of conditions, neither ether 19 nor the corresponding alcohol 20 participated in IMDA cycloaddition reactions to give the hoped-for adducts 21 and 22, respectively. Accordingly, alternate routes to such seven-membered ring-containing compounds were pursued.

\section{Scheme 3}

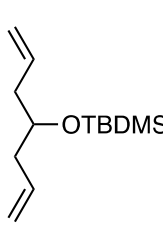

16

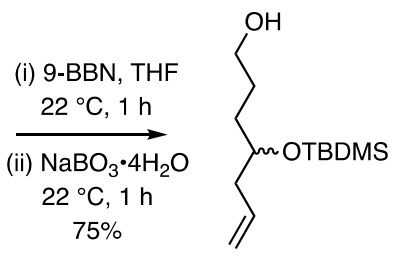

17

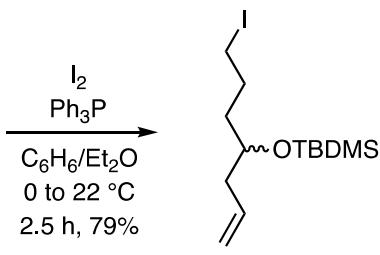

18
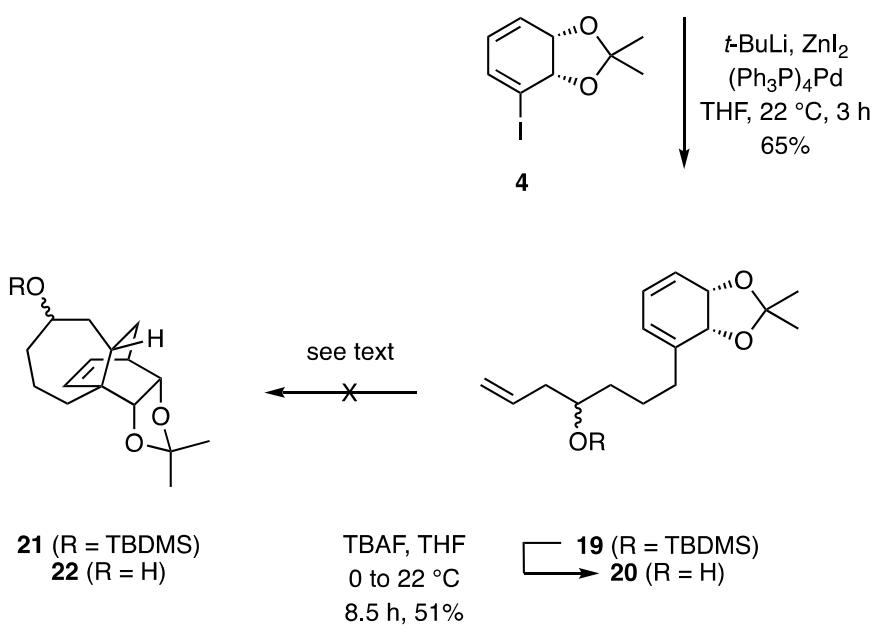

Our failure to establish a direct route to seven-membered ring homologues of compound 2 prompted exploration of an approach wherein cyclopropanated derivatives of the parent framework would be assembled with the intention of subjecting these to ring-expansion

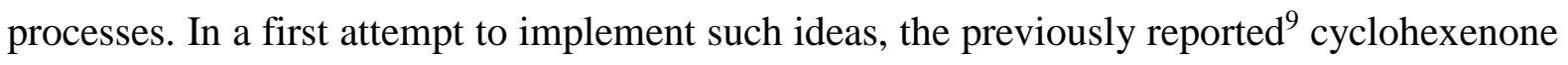
23 (Scheme 4), and a readily obtained derivative of compound 7, was subjected to reaction with the Corey-Chaykovsky ylide ${ }^{11}$ in the hope of effecting a nucleophilic cyclopropanation reaction. However, this did not occur. Rather, a complex reaction mixture was obtained and spectroscopic analysis of this indicated the presence of olefinic protons and the absence of a 
carbonyl group and thus suggesting the spirocyclic epoxide $\mathbf{2 4}$ may have been formed (the illustrated configuration at the spirocyclic center is suggested on the basis that nucleophilic additions to substrates such as $\mathbf{2 3}$ take place preferentially from the sterically more accessible $\beta$-face). However, pure samples of compound 24 could not be obtained and so exhaustive characterization of this product was not possible.

A directed electrophilic cyclopropanation pathway (Scheme 4) was also pursued in efforts to obtain the target ring system. Thus, Luche reduction ${ }^{12}$ of enone 23 afforded the $\alpha$-configured allylic alcohol 25 (87\%) stereoselectively and on subjecting this to a Furukawa-modified Simmons-Smith cyclopropanation reaction ${ }^{13}$ then compound 26 was obtained, as a single diastereoisomer, in 77\% yield. Oxidation of alcohol 26 with the Dess-Martin periodinane $(\mathrm{DMP})^{14}$ then gave the corresponding cyclopropyl ketone 27 (95\%) and on treatment of the

\section{Scheme 4}

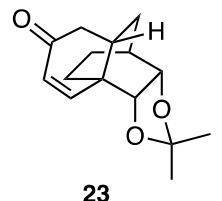

23

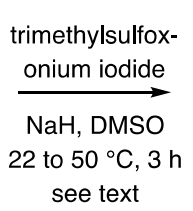

see text

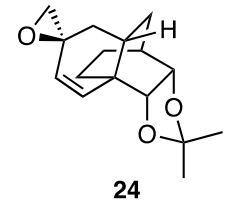

24
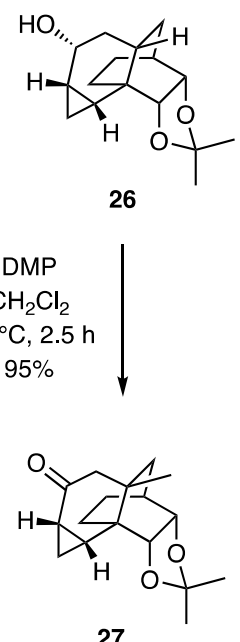

27

28
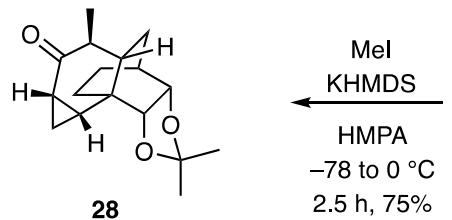

2.5 h, $75 \%$

26
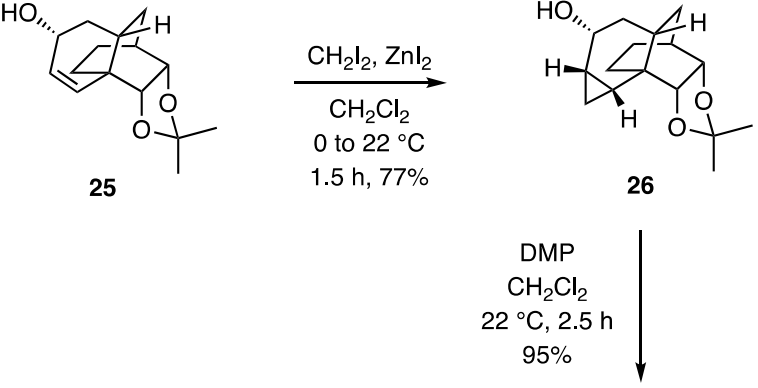
derived enolate with methyl iodide then the mono-methylated ketone 28 (75\%) was obtained as a crystalline solid and a single-crystal X-ray analysis of this material served to confirm the illustrated structure. Details of this analysis, including the derived ORTEP, are provided in the supporting information (SI) section.

The outcomes of the conversions $23 \rightarrow \mathbf{2 5}$ and $\mathbf{2 7} \rightarrow \mathbf{2 8}$ shown in Scheme 4 serve to emphasize that while $\beta$-face attack on such substrates tends to be favored, $\alpha$-face addition processes (such as $\mathbf{2 5} \rightarrow \mathbf{2 6}$ ) can still be effected through reagent complexation by appropriately $(\alpha)$ configured directing groups.

Various efforts were made to effect the ring-expansion of compounds 26, 27 and 28 but these either returned the starting materials or produced complex mixtures of products. As such, attempts to convert these cyclopropannulated cyclohexanes into seven-membered ringcontaining systems such as $\mathbf{2 2}$ were abandoned.

In seeking to obtain the rearranged enone 14, another of our original targets, the nucleophilic epoxidation of enone 23 (Scheme 5) was explored.

\section{Scheme 5}

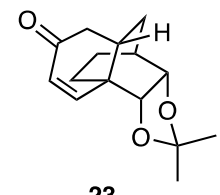

23

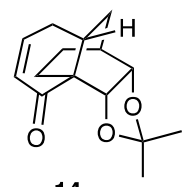

14

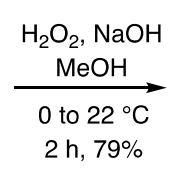

$$
\begin{gathered}
\mathrm{H}_{2} \mathrm{NNH}_{2} \cdot \mathrm{H}_{2} \mathrm{O} \\
\mathrm{AcOH} \\
0 \text { to } 22{ }^{\circ} \mathrm{C} 2 \mathrm{~h}, 71 \%
\end{gathered}
$$

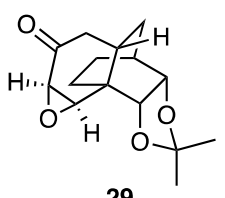

29

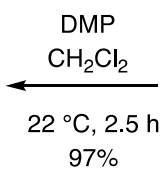

$97 \%$

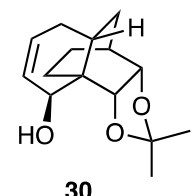

30 
This proceeded effectively on exposure of the substrate to alkaline hydrogen peroxide and thus affording compound $\mathbf{2 9}$ in $\mathbf{7 9 \%}$ yield. While the configuration of this epoxide proved to be of little consequence in terms of outcomes of the subsequent Wharton rearrangement, ${ }^{15}$ it is presumed to possesses the illustrated stereochemistry as a result of preferential $\beta$-face addition of the hydroperoxy anion to the enone moiety of the substrate. That said, inspection of the ${ }^{13} \mathrm{C}$ NMR spectrum of this product suggested that small amounts (ca. 10\%) of the other diastereoisomer were also likely to have been formed in the reaction. On treating this epoxyketone with hydrazine in the presence of acetic acid the anticipated reaction took place and so affording the allylic alcohol 30 in $71 \%$ yield. DMP-mediated oxidation of this last compound then gave the rearranged enone 14 (97\%), the spectral features of which were similar but not identical with those of precursor 23. Perhaps the most notable difference was evident in the ${ }^{1} \mathrm{H}$ NMR spectra. In compound $\mathbf{1 4}$ the resonance due to the $\beta$-proton of the enone moiety appeared at $\delta 6.83$ as a doublet of doublet of doublets $(J=10.2,5.8$ and 2.2 $\mathrm{Hz}$ ) while in precursor 23 this resonated at $\delta 6.89$ as a doublet $(J=10.1 \mathrm{~Hz}){ }^{9}$

In another conjugate addition process (Scheme 6), compound 23 was treated with the Gilman reagent and thus affording the $\beta$-methylated cyclohexanone 31 in $71 \%$ yield. On exposing this compound to a mixture of 2-iodoxybenzoic acid (IBX) and 4-methoxypyridine $\mathrm{N}$-oxide (MPO), under conditions defined by Nicolaou and co-workers, ${ }^{16}$ a chromatographically inseparable 2:3 mixture of the methylated and regioisomeric cyclohexenones $\mathbf{1 5}$ and $\mathbf{3 2}$ was obtained in $79 \%$ yield. Interestingly, this mixture of compounds proved to be crystalline and an X-ray analysis revealed the presence of one molecule of each of compounds $\mathbf{1 5}$ and $\mathbf{3 2}$ in the unit cell. Once again, details of this analysis are provided in the Experimental Section and the Supporting Information. 


\section{Scheme 6:}
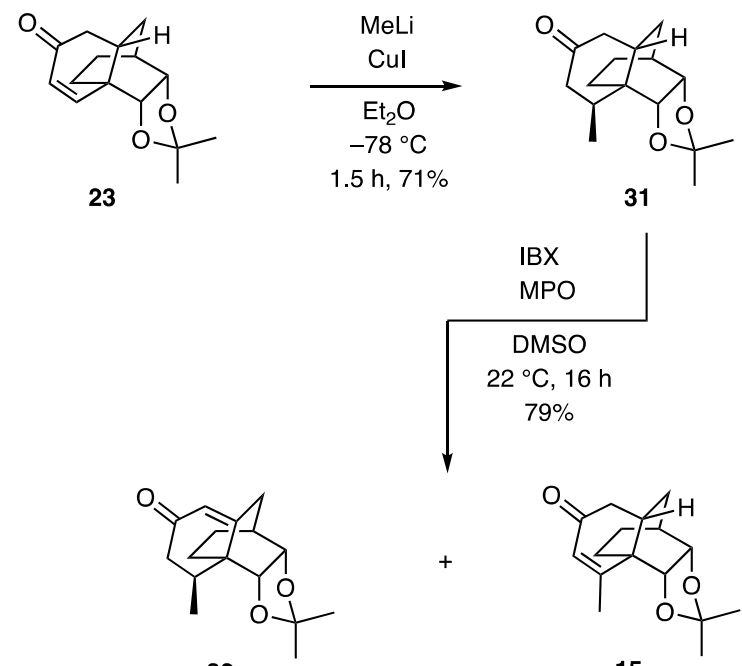

32

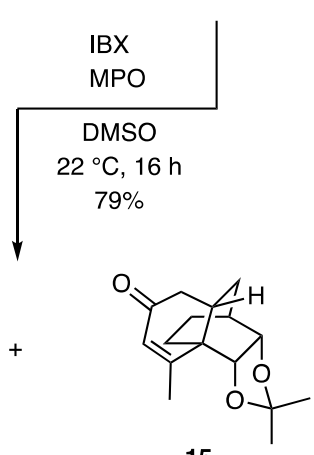

15

In an effort to establish the effect that other, adjacent functionalities might have on the regioselectivities of these types of dehydrogenation reactions, the unsaturated cyclohexanone 33 (Scheme 7), which is readily prepared from IMDA adduct 7 (see Experimental for details), was also subjected to reaction with IBX and MPO. Under such conditions essentially the same outcome was observed, namely a 1:3 mixture of the regioisomeric dienones 34 and 35 was formed in $86 \%$ combined yield. Gratifyingly, these could be separated chromatographically and each was subjected to single-crystal X-ray analysis, details of which are provided in the SI. 


\section{Scheme 7}

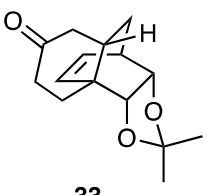

33
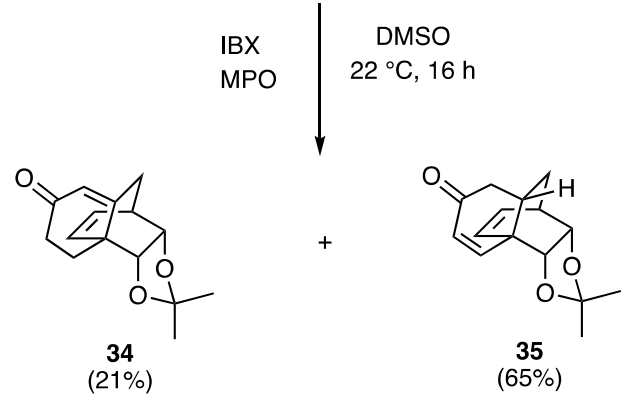

Having established various protocols for manipulating the cyclohexenone-containing core of platencin our attention turned to the application enolate alkylation protocols so as to determine how readily the $\alpha$-methyl and propionic acid "side-chain” groups seen in platencin could be installed in a stereoselective manner. The protocols developed for this purpose were, of course, informed by our earlier study ${ }^{9}$ on the total synthesis of platencin and a representative set of outcomes is shown in Scheme 8. Thus, the enolate obtained on treating enone 36 with potassium hexamethyldisilazide (KHMDS) at $-78{ }^{\circ} \mathrm{C}$ was treated with methyl iodide and the ensuing mixture allowed to warm to $0{ }^{\circ} \mathrm{C}$ over $2.5 \mathrm{~h}$. After work-up and chromatography three products, namely the mono-methylated compounds 37 (23\%) and 38 (51\%) together with the gem-dimethylated congener 39 (7\%), were obtained and the structure of the first of these was confirmed by single-crystal X-ray analysis. On treating the monomethylated system 38 with t-butyl acrylate in the presence of potassium t-butoxide the anticipated Michael addition reaction took place and so producing propionate ester 40 (57\%) as the major reaction product. NMR analysis of the crude reaction product also suggested the presence of traces of epimer $\mathbf{4 1}$ but this could not be isolated in pure form in sufficient quantities to allow for its independent spectroscopic characterization. The illustrated configurations of the newly established quaternary carbons in these esters are assigned on the basis that the major product of reaction should be that in which the acrylate reacts preferentially at the $\beta$-face of the enolate. 


\section{Scheme 8:}

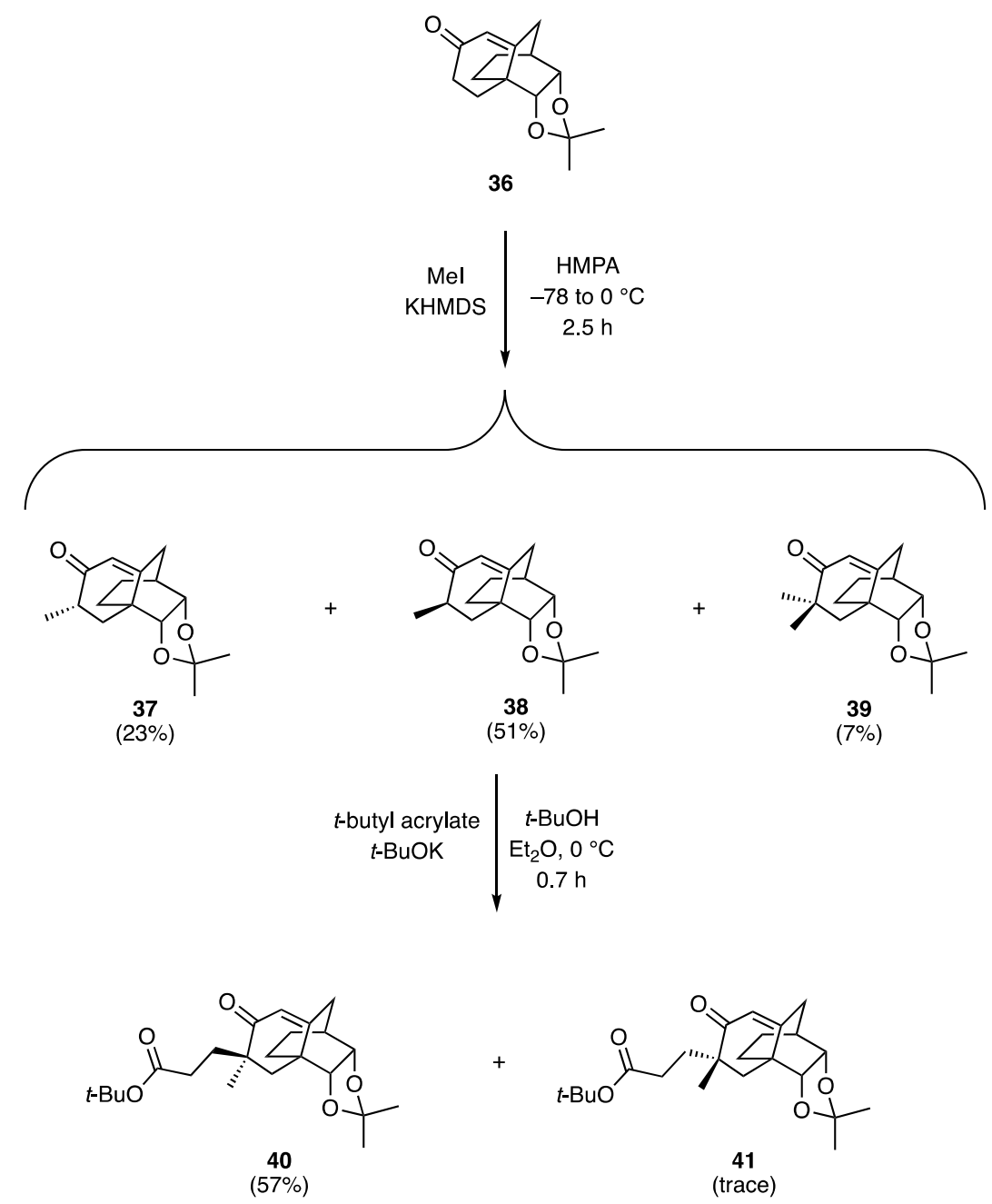

After work-up and chromatography three products, namely the mono-methylated compounds 37 (23\%) and 38 (51\%) together with the gem-dimethylated congener 39 (7\%), were obtained and the structure of the first of these was confirmed by single-crystal X-ray analysis. On treating the mono-methylated system 38 with $t$-butyl acrylate in the presence of potassium $t$ butoxide the anticipated Michael addition reaction took place and so producing propionate ester 40 (57\%) as the major reaction product. NMR analysis of the crude reaction product also suggested the presence of traces of epimer $\mathbf{4 1}$ but this could not be isolated in pure form in sufficient quantities to allow for its independent spectroscopic characterization. The illustrated configurations of the newly established quaternary carbons in these esters are 
assigned on the basis that the major products should be those in which the acrylate reacts preferentially at the $\beta$-face of the enolate.

Another aspect of our intelligence gathering activities in the area was an investigation of the capacity to effect selective manipulations of the acetonide moiety in systems incorporating cyclohexenone and propionate residues using the repertoire of transformations that we had employed earlier. ${ }^{8,9}$ The substrate we chose for such purposes was compound $\mathbf{4 2}$ (Scheme 9) that had been obtained previously as a minor product from successive methylation and propionylation reactions of enone $\mathbf{2 3}$ using the same conditions as described immediately above. Thus, treating acetonide $\mathbf{4 2}$ with acidified DOWEX-50 resin in methanol/THF/water at $65{ }^{\circ} \mathrm{C}$ for $36 \mathrm{~h}$ afforded diol 43 in $61 \%$ yield (at $79 \%$ conversion). Gratifyingly, there was little evidence for the competing cleavage of the $t$-butyl ester moiety under these conditions. The selective oxidation of the hydroxyl group remote from the bridgehead substituted carbon of the bicyclo[2.2.2]octane framework within compound $\mathbf{4 3}$ could be achieved using Bobbitt's reagent, ${ }^{17}$ namely the sterically demanding oxammonium salt derived from the $p$ toluenesulfonic acid-promoted disproportionation of 4-NHAc-(2,2,6,6-tetramethylpiperidin1-yl)oxidanyl (TEMPO). By such means the acyloin $\mathbf{4 4}$ was obtained in $85 \%$ yield and with no evidence for the co-production of its regio-isomer. Acetylation of compound $\mathbf{4 4}$ was achieved under conventional conditions and the resulting ester 45 (75\%) was subjected to reductive deoxygenation using Torii's low-valent vanadium reagent ${ }^{18}$ and thus affording the ketone 46 in 85\% yield. Chen and co-workers have reported ${ }^{19}$ the elaboration of compound 46, over 3 steps, into amide 47, the C-4 epimer of platencin and a compound that displays somewhat weaker anti-bacterial activity than the natural product. 


\section{Scheme 9:}
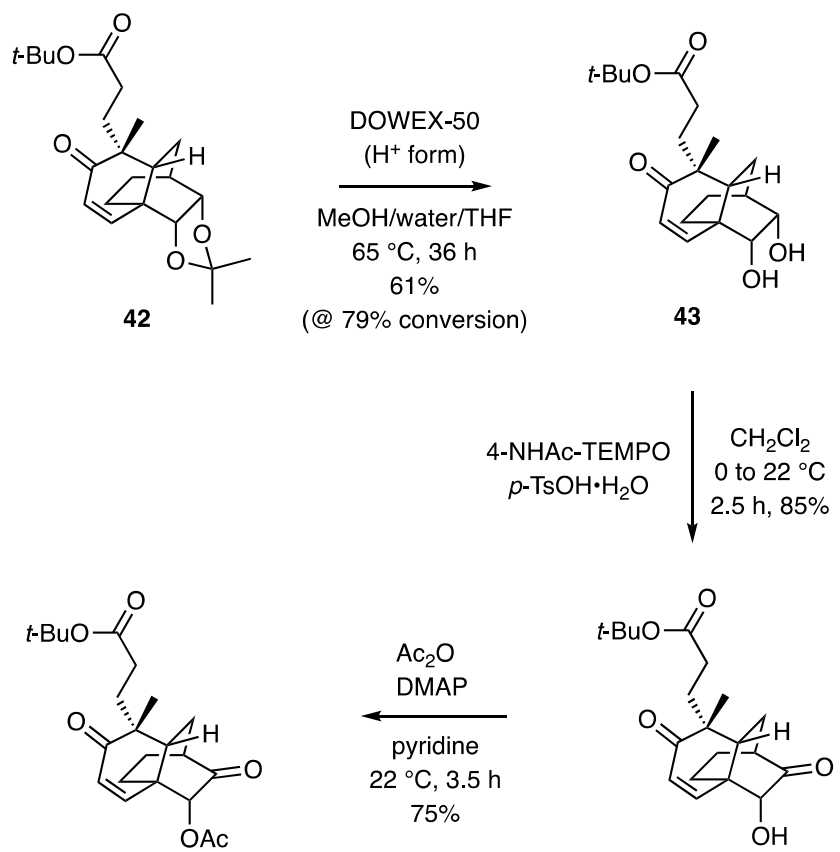

45

44

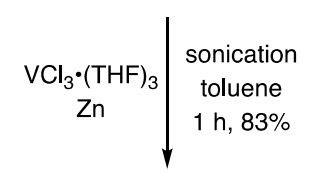

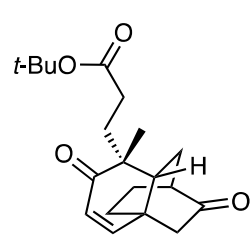

46

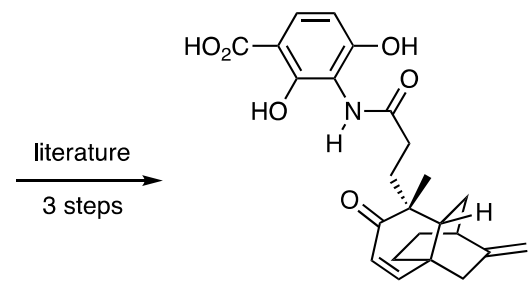

47

In a series of related transformations, as shown in Scheme 10, the enolate anion obtained by

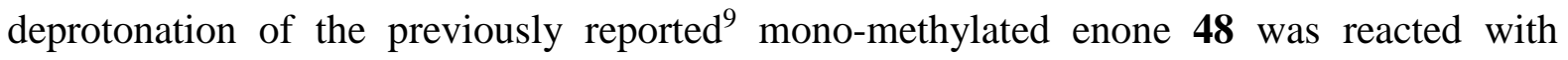
methyl acrylate and thus affording a 5:1 mixture of the epimeric propionic acid methyl esters 49 (72\%) and 50 (14\%). The acetonide residue associated with the major product, which is assumed to possess the illustrated $\beta$-configuration of the propionoate side-chain at C-4, could be cleaved under standard conditions and the resulting diol 51 (78\% at 85\% conversion) selectively oxidized using Bobbitt's reagent ${ }^{17}$ and thus affording acyloin 52 (93\%) that was 
itself esterified using benzoyl chloride in the presence of 4-( $N, N$-dimethylamino)pyridine (DMAP) and triethyamine and thus yielding compound 53 in 89\% yield. Selective Wittig methylenation of the non-conjugated ketone residue within this last compound could be accomplished under relatively conventional conditions and so giving the allylic ester $\mathbf{5 4}$ in $71 \%$ yield.

\section{Scheme 10:}

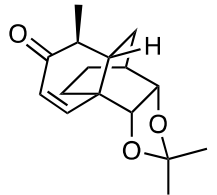

48 methyl acrylate $t$-BuOK

$\overrightarrow{\mathrm{Et}_{2} \mathrm{O}, t-\mathrm{BuOK}}$

$-10^{\circ} \mathrm{C}, 0.5 \mathrm{~h}$

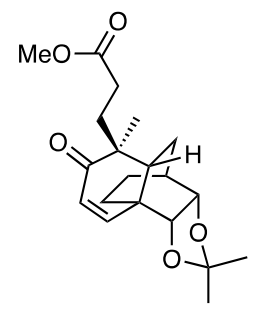

49
$(72 \%)$

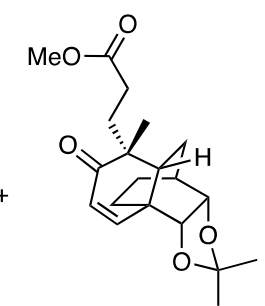

50

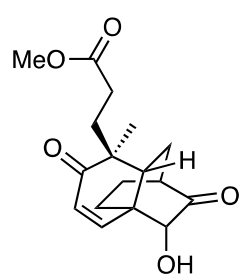

52
51

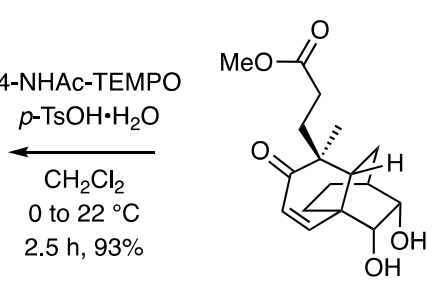

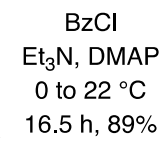

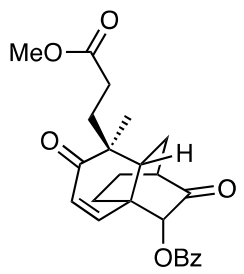

53

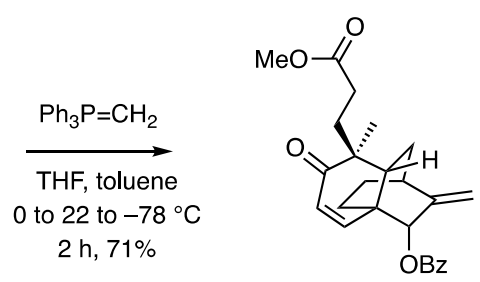

54 
The final focus of the present study was the conversion of certain propionic acid ester derivatives of the tricarbocyclic core framework, namely those incorporating an acetonide protecting group, into the corresponding $N$-aryl amides for the purposes of evaluating these as anti-infective agents. To such ends the reaction sequence shown in Scheme 11 was pursued and wherein ester $\mathbf{4 9}$ was saponified using lithium hydroxide in aqueous THF and the free-acid 55 (97\%) obtained on work up coupled, under conditions defined by Chen, ${ }^{19}$ with the protected aminobenzoic acid derivative $\mathbf{5 6}^{19}$ in the presence of 1[bis(dimethylamino)-methylene]-1H-1,2,3-triazolo[4,5-b]pyridinium 3-oxid hexafluorophosphate (HATU) $)^{20}$ and thus forming the amide 57 (32\%). Finally, treatment of this TMSEester-containing compound with tris(dimethylamino)sulfonium difluorotrimethylsilicate $(\text { TASF })^{21}$ resulted in the formation target $\mathbf{5 8}$ although repeated chromatographic purification was required to obtain material of appropriate quality and as a consequence this compound was only obtained in $21 \%$ yield.

\section{Scheme 11:}
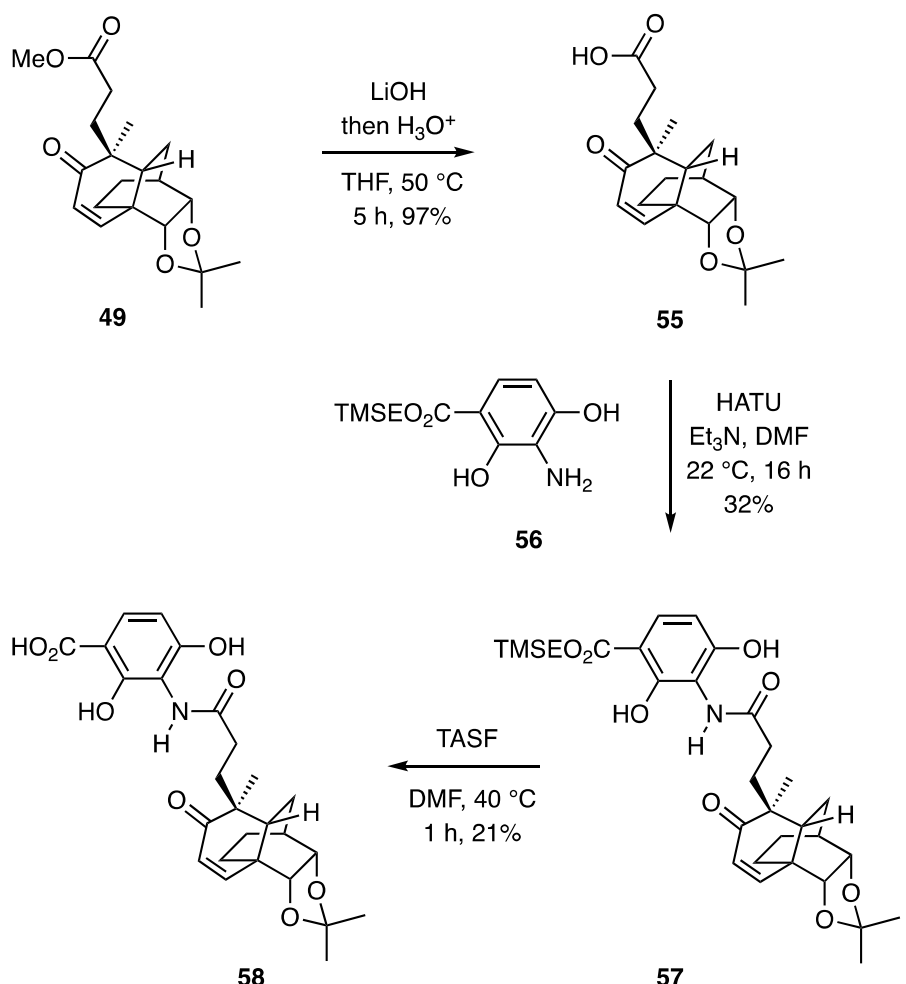

57 
The C-4 epimer of compound $\mathbf{5 8}$ was prepared in a slightly more direct manner as shown in Scheme 12. Thus, ester 50, was saponified in the same way as congener $\mathbf{4 9}$ and the resulting free-acid 59 (95\%) obtained after acidic work-up was coupled with the unprotected aminobenzoic acid $\mathbf{6 0}$ using 1-ethyl-3-(3-dimethylaminopropyl)carbodiimide (EDC) and so providing the target $N$-aryl amide $\mathbf{6 1}$ (27\%). The lack of a clean reaction associated with this coupling reaction led us to conclude that despite the need to employ an extra step (viz. a deprotection reaction) in the reaction sequence, couplings involving the protected aminobenzoic acid $\mathbf{5 6}$ (rather than congener 60) lead to superior outcomes.

\section{Scheme 12:}
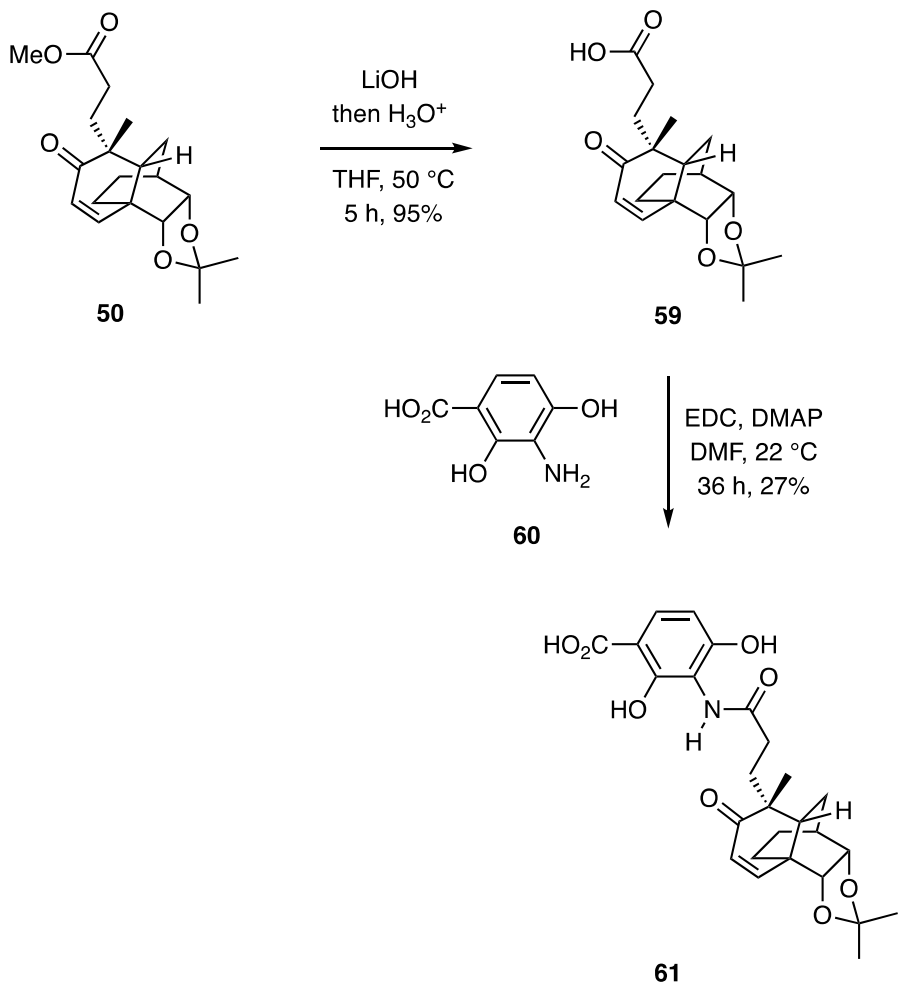

There are some modest differences in the spectroscopic data sets derived from the epimeric platencin analogues 58 and 61, perhaps the most conspicuous being in the high-field regions of the ${ }^{13} \mathrm{C}$ NMR spectra with the signals due to certain of the $\mathrm{sp}^{3}$-hybridized carbons in the latter compound being more shielded by the “overhanging” $N$-aryl amide residue. 
The final, acetonide-containing platencin analogue to be prepared was the saturated equivalent of compound 58. This was obtained by the simple route shown in Scheme 13. Specifically, the previously reported ${ }^{8}$ acid $\mathbf{6 2}$ was coupled with aniline $\mathbf{5 6}$ and so affording amide 63 (14\%) that was deprotected with TASF and thus delivering the third target analogue, namely compound 64, in 15\% yield. Once again, the low yields observed in this sequence derived from the need to subject each product to extensive flash column chromatography so as to secure material of adequate purity.

\section{Scheme 13:}

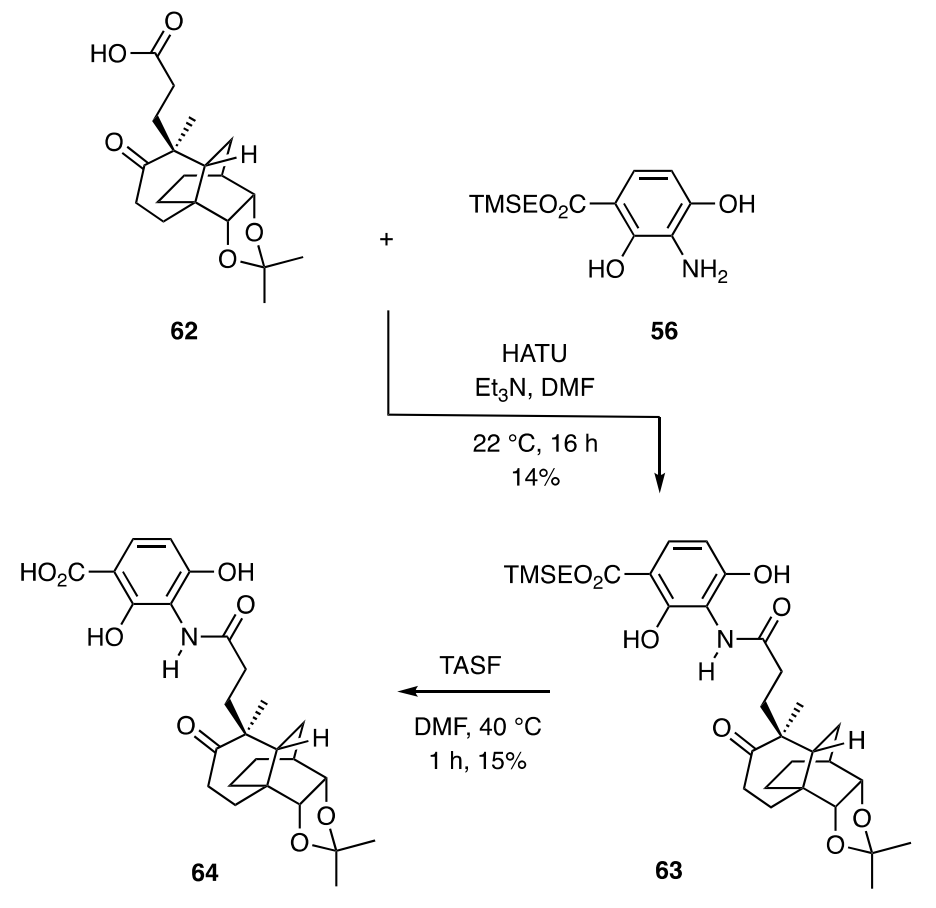

\section{Biological Studies}

The acetonide-containing platencin analogues 58, 61 and 64 were evaluated against a panel of Gram-positive bacteria including Streptococcus pynogens ATCC 51339, Staphylococcus aureus ATCC 19636, Enterococcus faecium ATCC 19434, and Haemophilus influenzae ATCC 49247. Commercially available platencin (1) and chloramphenicol were used as positive controls. Such evaluations established these analogues displayed the same activity against S. pynogens and E. faecium as that observed for platencin, namely that they were only 
weakly active materials $(>16 \mu \mathrm{g} / \mathrm{mL})$. In contrast, platencin inhibited the growth of $S$. aureus and $H$. influenzae at $4 \mu \mathrm{g} / \mathrm{mL}$ but analogues 58, 61 and 64 proved ineffective against all four of these same pathogens as revealed by their anti-bacterial activities being above $16 \mu \mathrm{g} / \mathrm{mL}$. These biological data are all summarized in Table 1.

Table 1: Comparison of the anti-bacterial properties of compounds 58, 61 and 64 with a naturally-derived sample of platencin and with chloramphenicol. ${ }^{[\mathrm{a}, \mathrm{b}]}$

\begin{tabular}{|c|c|c|c|c|}
\hline Compound & $\begin{array}{c}\text { Streptococcus } \\
\text { pynogens } \\
\text { ATCC 51339 }\end{array}$ & $\begin{array}{c}\text { Staphylococcus } \\
\text { aureus ATCC } \\
19636\end{array}$ & $\begin{array}{c}\text { Enterococcus } \\
\text { faecium ATCC } \\
19434\end{array}$ & $\begin{array}{c}\text { Haemophilus } \\
\text { influenzae } \\
\text { ATCC 49247 }\end{array}$ \\
\hline $\mathbf{5 8}$ & $>16$ & $>16$ & $>16$ & $>16$ \\
\hline $\mathbf{6 1}$ & $>16$ & $>16$ & $>16$ & $>16$ \\
\hline $\mathbf{6 4}$ & $>16$ & $>16$ & $>16$ & $>16$ \\
\hline platencin (1) & 4 & $>16$ & $\leq 2.0$ & $\leq 2.0$ \\
\hline chloroamphenicol & $\leq 2.0$ & $\leq 2.0$ & 4 & $>16$ \\
\hline
\end{tabular}

[a] MIC: The minimal inhibitory concentration (MIC) is the lowest compound concentration needed to inhibit visible bacteria growth or to inhibit growth based on absorbance readings. Streptococcus pyogenes ATCC 51339, Enterococcus faecium ATCC 19434, Staphylococcus aureus ATCC 19636 and Haemophilus influenzae ATCC 49247. Compounds were tested in doubling dilutions over the concentration range: $0.008-16 \mu \mathrm{g} / \mathrm{ml}$.

[b] These assays were conducted by associates of Dr Alistair Draffan at Biota Holdings Pty Limited, Melbourne, Australia.

\section{Conclusion}

The work detailed above has provided the capacity to generate a range of analogues of the tricarbocyclic core of platencin. While previous studies have established that modest variations in this core allow for the retention of anti-bacterial activity, ${ }^{2 b}$ the incorporation of an acetonide residue into such a framework (as seen in compounds 58, 61 and 64) at the expense of the exocyclic double bond (as seen in the natural product) clearly has adverse impacts. Nevertheless, other opportunities for variations within this framework are likely to be available through the transformations reported here and these are now being pursued. The outcomes of such studies will be reported in due course. 


\section{Experimental}

\section{General Experimental Procedures}

Unless otherwise specified, proton $\left({ }^{1} \mathrm{H}\right)$ and carbon $\left({ }^{13} \mathrm{C}\right)$ NMR spectra were recorded at 18 ${ }^{\circ} \mathrm{C}$ in base-filtered $\mathrm{CDCl}_{3}$ on a Varian spectrometer operating at $400 \mathrm{MHz}$ for proton and 100 $\mathrm{MHz}$ for carbon nuclei. For ${ }^{1} \mathrm{H}$ NMR spectra, signals arising from the residual protio-forms of the solvent were used as the internal standards. ${ }^{1} \mathrm{H}$ NMR data are recorded as follows: chemical shift $(\delta \square \square \square$ multiplicity, coupling constant(s)J (Hz), relative integral] where multiplicity is defined as: $\mathrm{s}=$ singlet; $\mathrm{d}$ = doublet; $\mathrm{t}=$ triplet; $\mathrm{q}=$ quartet; $\mathrm{m}=$ multiplet or combinations of the above. The signal due to residual $\mathrm{CHCl}_{3}$ appearing at $\delta_{\mathrm{H}} 7.26$ and the central resonance of the $\mathrm{CDCl}_{3}$ "triplet" appearing at $\delta_{\mathrm{C}} 77.0$ were used to reference ${ }^{1} \mathrm{H}$ and ${ }^{13} \mathrm{C}$ NMR spectra, respectively. Infrared spectra $\left(v_{\max }\right)$ were recorded on a Perkin-Elmer 1800 Series FTIR Spectrometer. Samples were analyzed as thin films on $\mathrm{KBr}$ plates. Lowresolution ESI mass spectra were recorded on a Micromass LC-ZMD single quadrupole liquid chromatograph-mass spectrometer while high-resolution measurements were conducted on an LCT Premier time-of-flight instrument. Low- and high-resolution EI mass spectra were recorded on an Autospec Premier Micromass magnetic-sector machine. Optical rotations were recorded in $\mathrm{CHCl}_{3}$ at $20{ }^{\circ} \mathrm{C}$ on a Perkin Elmer Model 343 Polarimeter. Melting points were measured on an Optimelt automated melting point system and are uncorrected. Analytical thin layer chromatography (TLC) was performed on aluminumbacked $0.2 \mathrm{~mm}$ thick silica gel $60 \mathrm{~F}_{254}$ plates as supplied by Merck. Eluted plates were visualized using a $254 \mathrm{~nm}$ UV lamp and/or by treatment with a suitable dip followed by heating. These dips included phosphomolybdic acid : ceric sulfate : sulfuric acid (conc.) : water (37.5 g : $7.5 \mathrm{~g}: 37.5 \mathrm{~g}: 720 \mathrm{~mL}$ ) or potassium permanganate : potassium carbonate : 5\% sodium hydroxide aqueous solution : water (3 g : $20 \mathrm{~g}: 5 \mathrm{~mL}: 300 \mathrm{~mL}$ ). Flash chromatographic separations were carried out following protocols defined by Still et al. ${ }^{22}$ with silica gel 60 (40-63 Sslinga) as the stationary phase and using the AR- or HPLCgrade solvents indicated. Starting materials and reagents were generally available from the Sigma-Aldrich, Merck, TCI, Strem or Lancaster Chemical Companies and were used as supplied. Drying agents and other inorganic salts were purchased from the AJAX, BDH or Unilab Chemical Companies. Tetrahydrofuran (THF), methanol and dichloromethane (DCM) were dried using a Glass Contour solvent purification system that is based upon a technology 
originally described by Grubbs et al. ${ }^{23}$ Where necessary, reactions were performed under an inert atmosphere. Semi-preparative HPLC separations were carried out using a 10 x $250 \mathrm{~mm}$ i.d. Daicel Chiral Pak 1A column packed with amylose tris(3,5-dimethylphenyl carbamate) immobilized on $5 \mu \mathrm{m}$ silica gel. 9:90:1 $\mathrm{v} / \mathrm{v} / \mathrm{v}$ iso-Propanol/ hexane/TFA was used as the eluting solvent at a flow rate of $4.5 \mathrm{~mL} / \mathrm{min}$.

\section{Specific Synthetic Transformations}

\section{Compound 16}

A magnetically stirred solution of commercially available hepta-1,6-dien-4-ol (13.45 g, 0.12 mol) in dry $\mathrm{CH}_{3} \mathrm{CN}(50 \mathrm{~mL})$ maintained under nitrogen atmosphere at $22{ }^{\circ} \mathrm{C}$ was treated with tert-butyldimethylsilyl chloride (TBDMS-Cl) $(19.6 \mathrm{~g}, 0.13 \mathrm{~mol})$ and the resulting mixture stirred for a further $0.25 \mathrm{~h}$ then treated, in portions, with imidazole ( $250 \mathrm{mg}, 1.0 \mathrm{mmol}$ ). The reaction mixture thus obtained was left to stir for $16 \mathrm{~h}$ before being diluted with hexane (90 $\mathrm{mL})$ then washed with water $(1 \times 35 \mathrm{~mL})$ and brine $(1 \times 35 \mathrm{~mL})$ before being dried $\left(\mathrm{Na}_{2} \mathrm{SO}_{4}\right)$, filtered and concentrated under reduced pressure. The resulting viscous light-yellow oil was subjected to flash column chromatography (silica, 1:9 v/v ethyl acetate/hexane elution) to afford, after concentration of the relevant fractions ( $R_{\mathrm{f}}=0.8$ in 3:7 $\mathrm{v} / \mathrm{v}$ ethyl acetate/hexane), compound 16 (24.7 g, 91\%) as a clear, colorless oil. ${ }^{1} \mathrm{H}$ NMR (400 MHz, $\left.\mathrm{CDCl}_{3}\right) \delta 5.90-5.74$ (complex m, 2H), 5.05 (m, 2H), 5.02 (s, 2H), 3.75 (p, J = 5.9 Hz, 1H), 2.33-2.10 (complex $\mathrm{m}, 4 \mathrm{H}), 0.89$ (s, 9H), 0.05 (s, 6H). These data matched those reported previously. ${ }^{5}$

\section{Compound 17}

A magnetically stirred solution of diene $\mathbf{1 6}^{5}(226 \mathrm{mg}, 1.0 \mathrm{mmol})$ in dry THF (19.0 mL) maintained at $22{ }^{\circ} \mathrm{C}$ under an atmosphere of nitrogen was treated, via syringe, with 9borabicyclo[3.3.1]nonane ( $2.56 \mathrm{~mL}$ of a $0.43 \mathrm{M}$ solution in THF, $1.1 \mathrm{mmol})$. The ensuing mixture was stirred for $1 \mathrm{~h}$ then treated with water $\left(7.5 \mathrm{~mL}\right.$ ) and $\mathrm{NaBO}_{3} \bullet 4 \mathrm{H}_{2} \mathrm{O}$ (5 equiv.) (CAUTION: exothermic reaction). The ensuing heterogeneous mixture was stirred vigorously for an additional $1 \mathrm{~h}$ then treated with $\mathrm{NH}_{4} \mathrm{Cl}$ (10 $\mathrm{mL}$ of a saturated aq. solution) before being extracted with ethyl acetate $(3 \times 15 \mathrm{~mL})$. The combined organic extracts were washed with brine $(1 \times 10 \mathrm{~mL})$ then dried $\left(\mathrm{MgSO}_{4}\right)$, filtered and concentrated under reduced pressure to give a clear, light-yellow oil. Subjection of this material to flash column 
chromatography (silica, 1:9 v/v ethyl acetate/hexane elution) afforded, after concentration of the relevant fractions, $\left(R_{\mathrm{f}}=0.5\right.$ in $1: 4 \mathrm{v} / \mathrm{v}$ ethyl acetate/hexane), the title alcohol $\mathbf{1 7}^{10}$ (183 mg, $75 \%$ ) as a clear, colorless liquid. ${ }^{1} \mathrm{H}$ NMR (400 MHz, $\left.\mathrm{CDCl}_{3}\right) \delta 5.78(\mathrm{~m}, 1 \mathrm{H}), 5.08-5.00$ (complex m, 2H), 3.79 (m, 1H), 3.62 (m, 2H), 2.25 (m, 2H), 1.98 (broad s, 1H), 1.69-1.50 (complex m, 4H), 0.89 (s, 9H), 0.06 (s, 6H); ${ }^{13} \mathrm{C}$ NMR (101 MHz, $\left.\mathrm{CDCl}_{3}\right) \delta$ 135.2, 117.1, 71.9, 63.3, 41.7, 33.2, 28.4, 26.0, 18.3, -4.3, -4.4; IR (KBr) $v_{\max } 3352,3077,2955,2930$, 2887, 2858, 1641, 1472, 1463, 1434, 1412, 1388, 1361, 1328, 1255, 1187, 1071, 1028, 1005, 969, 938, 912, 869, 836, 775, $665 \mathrm{~cm}^{-1}$; MS (ESI, +ve) m/z 267 [(M+Na) $\left.{ }^{+}, 20 \%\right], 70$ (100); HRESMS Found: $(\mathrm{M}+\mathrm{Na})^{+}$, 267.1756. $\mathrm{C}_{13} \mathrm{H}_{28} \mathrm{O}_{2} \mathrm{Si}$ requires $(\mathrm{M}+\mathrm{Na})^{+}$, 267.1756.

\section{Compound 18}

A magnetically stirred solution of alcohol $17(122 \mathrm{mg}, 0.5 \mathrm{mmol})$ in anhydrous diethyl ether $(10 \mathrm{~mL})$ maintained under an atmosphere of nitrogen was cooled to $0{ }^{\circ} \mathrm{C}$ then treated with imidazole (72 mg, $1.05 \mathrm{mmol}$ ), triphenylphosphine (262 mg, $1.0 \mathrm{mmol}$ ) and molecular iodine (255 mg, $1.05 \mathrm{mmol}$ ). The ensuing mixture was allowed to warm to $22{ }^{\circ} \mathrm{C}$ and stirred at this temperature for a further $2 \mathrm{~h}$. After this time, the now dark-colored reaction mixture was diluted with diethyl ether $(25 \mathrm{~mL})$ then $\mathrm{Na}_{2} \mathrm{~S}_{2} \mathrm{O}_{3}(7.5 \mathrm{~mL}$ of a $10 \% \mathrm{w} / \mathrm{v}$ aqueous solution). The separated aqueous phase was extracted with diethyl ether ( $3 \times 25 \mathrm{~mL})$ and the combined organic fractions washed with brine $(1 \times 15 \mathrm{~mL})$ before being dried $\left(\mathrm{Na}_{2} \mathrm{SO}_{4}\right)$, filtered and concentrated under reduced pressure to give a clear, light-yellow oil. Subjection of this material to flash column chromatography (silica, 1:9 v/v ethyl acetate/hexane elution) and concentration of appropriate fractions $\left(R_{\mathrm{f}}=0.5\right)$, afforded iodide $18(140 \mathrm{mg}, 79 \%)$ as a clear, colorless oil. ${ }^{1} \mathrm{H}$ NMR (400 MHz, $\left.\mathrm{CDCl}_{3}\right) \delta 5.79(\mathrm{~m}, 1 \mathrm{H}), 5.06(\mathrm{~m}, 1 \mathrm{H}), 5.02(\mathrm{~s}, 1 \mathrm{H})$, 3.74 (m, 1H), 3.18 (t, $J=7.0 \mathrm{~Hz}, 2 \mathrm{H}), 2.21$ (m, 2H), 1.99-1.76 (complex m, 2H), 1.63-1.44 (complex m, 2H), 0.88 (s, 9H), 0.05 (s, 6H); ${ }^{13} \mathrm{C}$ NMR (101 MHz, $\left.\mathrm{CDCl}_{3}\right) \delta 134.9,117.2$, 71.1, 42.0, 37.5, 29.6, 26.0, 18.2, 7.4, -4.2, -4.4; IR (KBr) $v_{\max } 2955$, 2928, 2850, 1641, 1471, 1462, 1436, 1361, 1255, 1071 1004, 913, 835, 774, $719 \mathrm{~cm}^{-1}$; MS (ESI, +ve) m/z 377 $\left[(\mathrm{M}+\mathrm{Na})^{+}, 100 \%\right]$; HRESMS Found: $(\mathrm{M}+\mathrm{Na})^{+}$, 377.0774. $\mathrm{C}_{13} \mathrm{H}_{27} \mathrm{IOSi}$ requires $(\mathrm{M}+\mathrm{Na})^{+}$, 377.0774. 


\section{Compound 19}

A magnetically stirred solution of iodide 18 (179 mg, $0.50 \mathrm{mmol})$ in diethyl ether (5 mL) maintained under nitrogen atmosphere at $-78{ }^{\circ} \mathrm{C}$ was treated dropwise, with $t$-BuLi $(617 \mu \mathrm{L}$ of a $1.7 \mathrm{M}$ solution in pentane, $1.05 \mathrm{mmol}$ ) over $3 \mathrm{~min}$. then stirred at this temperature for a further $5 \mathrm{~min}$. After this time a solution of anhydrous $\mathrm{ZnI}_{2}(175 \mathrm{mg}, 0.55 \mathrm{mmol})$ in dry THF $(750 \mu \mathrm{L})$ was added to the reaction mixture and stirring continued for a further $10 \mathrm{~min}$. before it was warmed to $22{ }^{\circ} \mathrm{C}$ over $1 \mathrm{~h}$. At this point, a solution of freshly prepared iodide 4 (140 mg, $0.5 \mathrm{mmol})$ and $\mathrm{Pd}\left(\mathrm{PPh}_{3}\right)_{4}(9 \mathrm{mg}, 0.08 \mathrm{mmol})$ in THF (750 $\left.\mu \mathrm{L}\right)$ was added, dropwise, then stirring continued for $2 \mathrm{~h}$. After this time the reaction mixture was quenched with $\mathrm{NaHCO}_{3}$ (10 mL of a saturated aqueous solution) and the separated aqueous phase extracted with diethyl ether ( 3 x $15 \mathrm{~mL}$ ). The combined organic phases were washed with brine $(1 \times 15 \mathrm{~mL})$ then dried $\left(\mathrm{Na}_{2} \mathrm{SO}_{4}\right)$, filtered and concentrated under reduced pressure to give a clear, light-yellow oil. This was subjected to flash column chromatography (1:99 to 1:19 $\mathrm{v} / \mathrm{v}$ ethyl acetate/hexane gradient elution) and afforded, after concentration of the relevant fractions ( $R_{\mathrm{f}}=0.4$ in $1: 4 \mathrm{v} / \mathrm{v}$ ethyl acetate/hexane), a ca. 1:1 mixture of the diastereoisomeric forms of compound 19 (123 mg, 65\%) as a clear, colorless oil. ${ }^{1} \mathrm{H}$ NMR (400 MHz, $\left.\mathrm{CDCl}_{3}\right) \delta 5.98$ (m, 1H), 5.84-5.75 (complex m, 2H), 5.72 (m, 1H), 5.05 (m, 2H), 4.64 (m, 1H), 4.52 (dd, $J=8.7$ and $2.5 \mathrm{~Hz}, 1 \mathrm{H}$ ), 3.71 (m, 1H), 2.27-2.18 (complex m, 4H), 1.43-144 (complex m, 4H), 1.41 (s, 3H), 1.39 (s, 3H), 0.89 (s, 9H), 0.05 (broadened s, 6H);

${ }^{13} \mathrm{C}$ NMR $\left(101 \mathrm{MHz}, \mathrm{CDCl}_{3}\right) \delta 138.5,135.9,135.5,128.4,125.7,124.9,124.8,122.7,118.4$, 116.8, 105.4, 86.1, 73.5, 71.9, 71.5, 42.2, 42.1, 36.6, 34.4, 33.8, 30.5, 27.1, 26.1, 25.2, 23.0(4), 22.9(7), 21.3, 18.3, -4.21, -4.4 (ten resonances obscured or overlapping); IR (KBr) $v_{\max }$ 3047, 2986, 2933, 2891, 1644, 1570, 1454, 1394, 1379, 1371, 1302, 1233, 1210, 1157, 1060, 1033, 982, 869, 787, 723, $622 \mathrm{~cm}^{-1}$; MS (ESI, +ve) m/z 401 [(M+Na) , 20\%], 147 (100); HRESMS Found: $(\mathrm{M}+\mathrm{Na})^{+}, 401.2487 . \mathrm{C}_{22} \mathrm{H}_{38} \mathrm{O}_{3} \mathrm{Si}$ requires $(\mathrm{M}+\mathrm{Na})^{+}, 401.2488$.

\section{Compound 20}

A magnetically stirred solution of silyl ether 19 (135 mg, $0.357 \mathrm{mmol})$ in THF (7.5 mL) maintained at $0{ }^{\circ} \mathrm{C}$ was treated with TBAF $(750 \mathrm{~mL} \mu \mathrm{L}$ of a $1.0 \mathrm{M}$ solution in THF, 0.75 $\mathrm{mmol})$. Stirring was continued for $0.25 \mathrm{~h}$ then the reaction mixture was warmed to $22{ }^{\circ} \mathrm{C}$ and stirring continued for further for $8 \mathrm{~h}$ at this temperature. After this time the reaction mixture 
was concentrated under reduced pressure and the residue thus obtained subjected to flash column chromatography (silica, 3:7 v/v ethyl acetate/hexane elution) to afford, after concentration of the relevant fractions $\left(R_{\mathrm{f}}=0.3\right.$ in $1: 1 \mathrm{v} / \mathrm{v}$ ethyl acetate/hexane), a ca. 1:1 mixture of the diastereoisomeric forms of compound 20 (47.6 mg, 51\%) as a clear, colorless oil. ${ }^{13} \mathrm{C}$ NMR (101 MHz, $\left.\mathrm{CDCl}_{3}\right) \delta 143.5,140.2,139.1,133.6,128.9,125.3,124.7,109.4$, 108.8, 106.0, 104.0, 101.5, 84.9, 79.2, 78.7, 77.9, 75.4, 71.7, 48.4, 45.7, 38.5, 35.4, 28.0, 26.9, 26.8, 25.6, 25.3 (five resonances obscured or overlapping); IR $v_{\max } 3415,3047,2983$, 2932, 1640, 1443, 1375, 1370, 1259, 1210, 1158, 1046, 914, 884, 747, $667 \mathrm{~cm}^{-1}$; MS (EI, 70 eV) $\mathrm{m} / \mathrm{z} 264\left(\mathrm{M}^{+\bullet},<1 \%\right), 263\left[(\mathrm{M}-\mathrm{H} \bullet)^{+}, 3\right], 249\left[\left(\mathrm{M}-\mathrm{CH}_{3}\right)^{+}, 100\right]$; HREIMS Found: $\mathbf{M}^{+\bullet}$, 264.1726. $\mathrm{C}_{16} \mathrm{H}_{24} \mathrm{O}_{3}$ requires $\mathrm{M}^{+}$, 264.1725.

\section{Attempted Nucleophilic Cyclopropanation of Enone 23}

A magnetically stirred suspension of sodium hydride (40 mg, $1.01 \mathrm{mmol}$ ) in DMSO (1.0 mL) was treated with trimethylsulfoxonium iodide (334 mg, $1.52 \mathrm{mmol}$ ) and the ensuing mixture stirred at $22{ }^{\circ} \mathrm{C}$ for $0.5 \mathrm{~h}$ then a solution of enone $23^{9}$ (24.8 $\left.\mathrm{mg}, 0.10 \mathrm{~mol}\right)$ in DMSO (1.0 mL) was added to the reaction mixture that was then stirred for a further $2.5 \mathrm{~h}$. After this time the reaction temperature was raised to $50{ }^{\circ} \mathrm{C}$ and stirring continued at this temperature for $0.5 \mathrm{~h}$. The cooled reaction mixture was then treated with diethyl ether $(5 \mathrm{~mL})$ followed by $\mathrm{pH} 7$ aqueous buffer ( $5 \mathrm{~mL}$ ). The separated aqueous phase was extracted with diethyl ether (5 x 10 $\mathrm{mL})$ and the combined organic phases were dried $\left(\mathrm{MgSO}_{4}\right)$, filtered and concentrated under reduced pressure to give a clear, light-yellow oil (21 mg). NMR spectroscopic and TLC analyses of this material suggested it was a mixture of products. The presence of olefinic

proton resonances in the ${ }^{1} \mathrm{H}$ NMR spectrum of the crude reaction mixture and the absence of a carbonyl absorption band in the infrared spectrum of this material suggested that spiroepoxidation (leading, at least in part, to compound 24), rather than nucleophilic cyclopropanation, had taken place.

\section{Compound 25}

A magnetically stirred solution of enone $23(1.24 \mathrm{~g}, 5.0 \mathrm{mmol})$ and $\mathrm{CeCl}_{3} \cdot 7 \mathrm{H}_{2} \mathrm{O}(3.71 \mathrm{~g}, 10.0$ mmol) in methanol $(19 \mathrm{~mL})$ was cooled to $0{ }^{\circ} \mathrm{C}$ then treated, in portions over $0.5 \mathrm{~h}$, with $\mathrm{NaBH}_{4}$ (375 mg, $10.0 \mathrm{mmol}$ ). The ensuing mixture was allowed to warm to $22{ }^{\circ} \mathrm{C}$ then 
stirred at this temperature for a further $2.5 \mathrm{~h}$ before water $(10 \mathrm{~mL})$ was slowly added. After hydrogen gas evolution had ceased the reaction mixture was concentrated under reduced pressure and the residue thus obtained extracted with dichloromethane $(5 \times 15 \mathrm{~mL})$. The combined organic phases were then dried $\left(\mathrm{Na}_{2} \mathrm{SO}_{4}\right)$, filtered and concentrated under reduced pressure to give a white, crystalline solid. Recrystallization (hexane/methanol) of this material gave alcohol $25(1.09 \mathrm{~g}, 87 \%)$ as a white, masses, m.p. $=108-116{ }^{\circ} \mathrm{C},[\alpha]_{\mathrm{D}}=-31.2$, ( $\left.c=1.0, \mathrm{CHCl}_{3}\right)\left(R_{\mathrm{f}}=0.3\right.$ in 3:7 v/v ethyl acetate/hexane). ${ }^{1} \mathrm{H}$ NMR $\left(400 \mathrm{MHz}, \mathrm{CDCl}_{3}\right) \delta$ 5.69 (dd, $J=10.1$ and $2.0 \mathrm{~Hz}, 1 \mathrm{H}$ ), 5.58 (m, 1H), 4.23 (m, 1H), 4.12 (m, 1H), 3.71 (dd, $J=$ 8.1 and $1.4 \mathrm{~Hz}, 1 \mathrm{H}), 2.04$ (m, 1H), 1.88-1.74 (complex m, 3H), 1.70-1.59 (complex m, 2H), 1.52 (s, 3H), 1.47 (m, 1H), 1.33 (s, 4H), 1.30 (m, 1H), 1.26-1.14 (complex m, 2H); ${ }^{13} \mathrm{C}$ NMR (101 MHz, $\left.\mathrm{CDCl}_{3}\right) \delta$ 134.0, 130.8, 108.7, 79.4, 75.9, 68.1, 36.3, 35.3, 31.8, 30.0, 29.9, 26.0, 24.4, 20.9, 19.5; IR (KBr) v $v_{\max } 3407,2987,2932,2868,1463,1373,1277,1260,1207,1163$, 1063, 1013, 994, 968, 931, 894, 876, 732, 647, $522 \mathrm{~cm}^{-1}$; MS (EI, $\left.70 \mathrm{eV}\right) \mathrm{m} / \mathrm{z} 250\left(\mathrm{M}^{+\bullet}\right.$, 18\%), $235\left[\left(\mathrm{M}^{-\mathrm{CH}_{3}}\right)^{+}, 100\right], 192$ (85), 157 (66), 148 (93), 130 (88), 105 (80), 91 (75); HREIMS Found: $\mathrm{M}^{+\bullet}$, 250.1568. $\mathrm{C}_{15} \mathrm{H}_{22} \mathrm{O}_{3}$ requires $\mathrm{M}^{+\bullet}$, 250.1569.

\section{Compound 26}

A magnetically stirred solution of allylic alcohol 25 (1.14 g, $4.5 \mathrm{mmol})$ in dry toluene (21 $\mathrm{mL}$ ) maintained under an argon atmosphere and protected from light was cooled to $0{ }^{\circ} \mathrm{C}$ before being treated, dropwise over $0.5 \mathrm{~h}$, with diethyl zinc $(13.5 \mathrm{~mL}$ of a $1 \mathrm{M}$ solution in hexane, $13.5 \mathrm{mmol})$ then diiodomethane $(1.01 \mathrm{~mL}, 13.1 \mathrm{mmol})$. After $0.5 \mathrm{~h}$ the reaction mixture was allowed to warm to $22^{\circ} \mathrm{C}$ and stirred at this temperature for $1.5 \mathrm{~h}$. $\mathrm{NH}_{4} \mathrm{Cl}(40$ $\mathrm{mL}$ of a saturated aqueous solution) was then carefully added to the reaction mixture which was then extracted with dichloromethane $(5 \times 25 \mathrm{~mL})$. The combined organic phases were washed successively with $\mathrm{NaHCO}_{3}(1 \times 15 \mathrm{~mL}$ of a saturated aqueous solution) and water (1 $\times 15 \mathrm{~mL})$ before being dried $\left(\mathrm{Na}_{2} \mathrm{SO}_{4}\right)$, filtered and concentrated under reduced pressure. The residue thus obtained was subjected to flash column chromatography (silica, 3:7 v/v ethyl acetate/hexane elution) to afford, after concentration of the appropriate fractions $\left(R_{\mathrm{f}}=0.25\right.$ in 1:4 v/v ethyl acetate/hexane), compound 26 (920 mg, 77\%) as a white, crystalline solid, m.p.

$=146-148{ }^{\circ} \mathrm{C},[\alpha]_{\mathrm{D}}=-63.1\left(c=1.0, \mathrm{CHCl}_{3}\right) .{ }^{1} \mathrm{H}$ NMR $\left(400 \mathrm{MHz}, \mathrm{CDCl}_{3}\right) \delta 4.17-4.08$ (complex m, 2H), 3.99 (dd, $J=8.0$ and $1.3 \mathrm{~Hz}, 1 \mathrm{H}$ ), 1.80 (m, 1H), 1.73-1.53 (complex m, 
6H), 1.57 (s, 3H), 1.37 (s, 3H), 1.31-0.97 (complex m, 6H), 0.41 (td, $J=8.9$ and $5.3 \mathrm{~Hz}$, 1H), 0.32 (q, $J=5.5 \mathrm{~Hz}, 1 \mathrm{H}) ;{ }^{13} \mathrm{C}$ NMR (101 MHz, $\left.\mathrm{CDCl}_{3}\right) \delta 108.5,82.2,76.2,69.1,35.1$, 32.0, 31.5, 30.3, 29.3, 26.1, 24.4, 22.1, 19.9, 19.7, 18.6, 3.1; IR (KBr) v $v_{\max } 3402$, 2987, 2930, 2865, 1469, 1380, 1371, 1283, 1259, 1207, 1164, 1143, 1098, 1085, 1065, 1031, 1009, 911, 876, $732 \mathrm{~cm}^{-1}$; MS (EI, $\left.70 \mathrm{eV}\right) \mathrm{m} / \mathrm{z} 249$ [(M-CH $\left.3^{\bullet}\right)^{+}, 100 \%$ ]; HREIMS Found: $\left(\mathrm{M}-\mathrm{CH}_{3} \bullet\right)^{+}$, 249.1498. $\mathrm{C}_{16} \mathrm{H}_{24} \mathrm{O}_{3}$ requires $\left(\mathrm{M}-\mathrm{CH}_{3} \bullet\right)^{+}$, 249.1491 .

\section{Compound 27}

A magnetically stirred solution of alcohol 26 (501 mg, $1.90 \mathrm{mmol})$ ) and DMP (481 mg, 2.85 $\mathrm{mmol})$ in dry dichloromethane $(25.0 \mathrm{~mL})$ was stirred at $22{ }^{\circ} \mathrm{C}$ for $0.25 \mathrm{~h}$ then concentrated under reduced pressure. The residue thus obtained was redissolved in a minimum volume of diethyl ether and the resulting solution washed with $\mathrm{Na}_{2} \mathrm{~S}_{2} \mathrm{O}_{3} / \mathrm{NaHCO}_{3}(1 \times 35 \mathrm{~mL}$ of a 1:1 $\mathrm{v} / \mathrm{v}$ mixture of $10 \% \mathrm{wt} / \mathrm{v}$ solution and a saturated aqueous solution, respectively) water ( $1 \times$ $20 \mathrm{~mL})$ and brine $(1 \times 20 \mathrm{~mL})$. The combined aqueous washings were extracted with diethyl ether $(1 \times 40 \mathrm{~mL})$ and the combined organic layers then dried $\left(\mathrm{Na}_{2} \mathrm{SO}_{4}\right)$, filtered, and concentrated under reduced pressure. Subjection of the residue thus obtained to flash column chromatography (silica 1:4 v/v ethyl acetate/hexane elution) afforded, after concentration of the appropriate fractions $\left(R_{\mathrm{f}}=0.4\right)$, ketone $27(474 \mathrm{mg}, 95 \%)$ as a white, crystalline solid, m.p. $=151-154,[\alpha]_{\mathrm{D}}=-51.7\left(c=1.0, \mathrm{CHCl}_{3}\right) .{ }^{1} \mathrm{H} \mathrm{NMR}\left(400 \mathrm{MHz}, \mathrm{CDCl}_{3}\right) \delta 4.26(\mathrm{~m}, 1 \mathrm{H})$, 4.07 (m, 1H), 2.21 (t, $J=13.8 \mathrm{~Hz}, 1 \mathrm{H}), 2.00$ (m, 1H), 1.93-1.61 (complex m, 7H), 1.53 (s, 3H), 1.36 (s, 3H), 1.30-1.09 (complex m, 3H), 1.06 (m, 1H), 0.95 (m, 1H); ${ }^{13} \mathrm{C}$ NMR (101 $\left.\mathrm{MHz}_{\mathrm{CDCl}}\right) \delta 209.5,108.7,81.6,76.0,40.0,38.6,32.3,30.4,29.7,28.7,26.0,25.5,24.4$, 19.7, 19.5, 13.5; IR (KBr) $v_{\max }$ 2993, 2985, 2954, 2896, 1693, 1453, 1380, 1372, 1271, 1256, 1209, 1130, 1068, 1038, 1025, 994, 948, 910, 862, 805, 778, 733, 644, $516 \mathrm{~cm}^{-1}$; MS (ESI, +ve) m/z 317 (73\%), 301 (100), $285\left[(\mathrm{M}+\mathrm{Na})^{+}, 50\right], 263$ (18); HRESMS Found: $(\mathrm{M}+\mathrm{Na})^{+}$, 285.1467. $\mathrm{C}_{16} \mathrm{H}_{22} \mathrm{O}_{3}$ requires $(\mathrm{M}+\mathrm{Na})^{+}$, 285.1467.

\section{Compound 28}

A magnetically stirred solution of compound 27 (263 mg, $1.00 \mathrm{mmol}$ ) in dry THF/HMPA (10

$\mathrm{mL}$ of a $3: 1 \mathrm{v} / \mathrm{v}$ mixture) and maintained under nitrogen at $-78{ }^{\circ} \mathrm{C}$ was treated, dropwise, with KHMDS (2.5 mL of a $0.5 \mathrm{M}$ solution in toluene, $1.25 \mathrm{mmol})$. The ensuing mixture was 
stirred at $-78{ }^{\circ} \mathrm{C}$ for $0.5 \mathrm{~h}$ then treated, dropwise, with iodomethane $(449 \mu \mathrm{L}$ of material freshly filtered through anhydrous $\mathrm{K}_{2} \mathrm{CO}_{3}, 7.00 \mathrm{mmol}$ ). The ensuing mixture was stirred for $0.5 \mathrm{~h}$ then allowed to warm $0{ }^{\circ} \mathrm{C}$ over a period of $1 \mathrm{~h}$ before being treated with $\mathrm{NaHCO}_{3}(10$ $\mathrm{mL}$ of a saturated aqueous solution) and extracted with dichloromethane (4 x $15 \mathrm{~mL})$. The combined organic extracts were washed with brine $(1 \times 10 \mathrm{~mL})$ then dried $\left(\mathrm{Na}_{2} \mathrm{SO}_{4}\right)$, filtered and concentrated under reduced pressure. The residue thus obtained was subjected to flash column chromatography (silica, 1:4 v/v ethyl acetate/hexane elution) to afford, after concentration of the appropriate fractions $\left(R_{\mathrm{f}}=0.5\right)$, compound 28 (197 mg, 75\%) as a white, crystalline solid, m.p. $=176-182,[\alpha]_{\mathrm{D}}=-32.1\left(c=1.0, \mathrm{CHCl}_{3}\right) .{ }^{1} \mathrm{H}$ NMR $(400 \mathrm{MHz}$, $\left.\mathrm{CDCl}_{3}\right) \delta 4.15$ (m, 1H), 4.07 (dd, $J=7.9$ and $1.4 \mathrm{~Hz}, 1 \mathrm{H}$ ), 2.20 (m, 1H), 1.97-1.58 (complex m, 7H), 1.54 (s, 3H), 1.37 (s, 3H), 1.32-1.21 (complex m, 3H), 1.05 (m, 1H), 0.98 (t, $J=3.3$ $\mathrm{Hz}, 1 \mathrm{H}), 0.95$ (d, $J=6.6 \mathrm{~Hz}, 3 \mathrm{H}) ;{ }^{13} \mathrm{C} \mathrm{NMR}\left(101 \mathrm{MHz}, \mathrm{CDCl}_{3}\right) \delta 211.2,108.9,81.6,75.8$, 46.0, 38.7, 32.7, 30.5, 28.7, 28.4, 26.0, 25.5, 24.4, 20.4, 19.7, 13.8, 10.8; IR (KBr) v $v_{\max } 2985$, 2937, 2897, 1688, 1456, 1374, 1354, 1285, 1257, 1208, 1161, 1130, 1086, 1064, 1044, 970, 935, 876, 829, 807, 738, 640, $509 \mathrm{~cm}^{-1}$; MS (ESI, +ve) m/z 331 (100\%), $299\left[(\mathrm{M}+\mathrm{Na})^{+}, 48\right]$, 277 (15); HRESMS Found: $(\mathrm{M}+\mathrm{Na})^{+}, 299.1623$. $\mathrm{C}_{17} \mathrm{H}_{24} \mathrm{O}_{3}$ requires $(\mathrm{M}+\mathrm{Na})^{+}$, 299.1623.

\section{Compound 29}

A magnetically stirred solution of enone 23 (150 mg, $0.60 \mathrm{mmol})$ in methanol $(25 \mathrm{~mL})$ was cooled to $0{ }^{\circ} \mathrm{C}$ then treated, successively, with hydrogen peroxide $(217 \mu \mathrm{L}$ of a $35 \% \mathrm{w} / \mathrm{v}$ aqueous solution, $2.1 \mathrm{mmol})$ and sodium hydroxide (109 $\mu \mathrm{L}$ of $6 \mathrm{M}$ aqueous solution, 0.65 $\mathrm{mmol}$ ). The ensuing mixture was warmed to $22^{\circ} \mathrm{C}$, stirred at this temperature for $1.5 \mathrm{~h}$ then poured into a mixture of ethyl acetate $(25 \mathrm{~mL})$ and $\mathrm{NH}_{4} \mathrm{Cl}(20 \mathrm{~mL}$ of a saturated aqueous solution). The separated aqueous layer was extracted with ethyl acetate $(4 \times 15 \mathrm{~mL})$ and the combined organic phases were then dried $\left(\mathrm{Na}_{2} \mathrm{SO}_{4}\right)$, filtered and concentrated under reduced pressure. The light-yellow residue thus obtained was subjected flash column chromatography (silica, 3:7:0.1 v/v/v ethyl acetate/hexane/acetic acid elution) to afford, after concentration of the appropriate fractions $\left(R_{\mathrm{f}}=0.5\right.$ in $3: 7: 0.1 \mathrm{v} / \mathrm{v} / \mathrm{v}$ ethyl acetate/hexane/acetic acid) compound 29 (127 mg, 79\%) as a white, crystalline solid m.p. $=79-80{ }^{\circ} \mathrm{C},[\alpha]_{\mathrm{D}}=+9.45(c=$ 1.0, $\mathrm{CHCl}_{3}$ ). ${ }^{1} \mathrm{H}$ NMR (400 MHz, $\mathrm{CDCl}_{3}$ ) $\delta 4.21-4.11$ (complex m, 2H), 3.43 (d, $J=3.9 \mathrm{~Hz}$, 1H), 3.25 (d, $J=3.9 \mathrm{~Hz}, 1 \mathrm{H}$ ), 2.61 (m, 1H), 2.08 (m, 1H), 2.00-1.08 (complex m, 6H), 1.54 
(s, 3H), 1.39 (s, 3H), 1.20 (m, 1H), 1.05 (m, 1H); $\left.{ }^{13} \mathrm{C} \mathrm{NMR} \mathrm{(101} \mathrm{MHz,} \mathrm{CDCl}_{3}\right) \delta$ 204.7, 109.1, 75.4, 59.1, 55.1, 41.8, 35.1, 31.1, 29.4, 25.9, 25.0, 24.3, 18.2, 16.2 (one resonance obscured or overlapping); IR (KBr) $v_{\max } 2935,2925,1710,1467,1406,1380,1260,1207$, 1163, 1115, 1067, 1031, 982, 918, 877, 854, 822, $803 \mathrm{~cm}^{-1}$; MS (EI, $\left.70 \mathrm{eV}\right) \mathrm{m} / \mathrm{z} 249$ [(M$\left.\mathrm{CH}_{3}\right)^{+}, 100 \%$ ]; HREIMS Found: $\left(\mathrm{M}-\mathrm{CH}_{3}\right)^{+}, 249.1130 . \mathrm{C}_{15} \mathrm{H}_{20} \mathrm{O}_{4}$ requires $\left(\mathrm{M}-\mathrm{CH}_{3}\right)^{+}$, 249.1127.

\section{Compound 30}

A magnetically stirred solution of epoxy-ketone 29 (105 $\mathrm{mg}, 0.4 \mathrm{mmol})$ in anhydrous methanol $\left(5 \mathrm{~mL}\right.$ ) was cooled to $0{ }^{\circ} \mathrm{C}$ then treated, dropwise, with hydrazine hydrate $(75 \mathrm{mg}$, $1.50 \mathrm{mmol}$ ). The ensuing mixture was stirred at $0{ }^{\circ} \mathrm{C}$ for $0.5 \mathrm{~h}$ before being warmed to $22{ }^{\circ} \mathrm{C}$ then treated, dropwise via syringe, with acetic acid (90 mg, $1.50 \mathrm{mmol})$. The ensuing mixture was stirred for a further $1.5 \mathrm{~h}$ at this temperature then diluted with dichloromethane (15 mL) and quenched (CAUTION: exothermic reaction with accompanying gas evolution) with $\mathrm{NaHCO}_{3}(10 \mathrm{~mL}$ of a saturated aqueous solution). The ensuing mixture was extracted with dichloromethane $(4 \times 15 \mathrm{~mL})$ and the combined organic phases washed with brine $(1 \times 20$ $\mathrm{mL}$ ) then dried $\left(\mathrm{MgSO}_{4}\right)$, filtered and concentrated under reduced pressure. The residue thus obtained was subjected to flash column chromatography (silica, 1:9 v/v ethyl acetate/hexanes elution) to afford, after concentration of the relevant fractions $\left(R_{\mathrm{f}}=0.5\right.$ in $1: 1 \mathrm{v} / \mathrm{v}$ ethyl acetate/hexane), compound 30 (71 mg, $71 \%$ ) as a white, crystalline solid, m.p. $=95-96{ }^{\circ} \mathrm{C}$, $[\alpha]_{\mathrm{D}}=+37.2\left(c=1.0, \mathrm{CHCl}_{3}\right) .{ }^{1} \mathrm{H} \mathrm{NMR}\left(400 \mathrm{MHz}, \mathrm{CDCl}_{3}\right) \delta 5.87(\mathrm{~m}, 1 \mathrm{H}), 5.78(\mathrm{~m}, 1 \mathrm{H})$, 4.24 (dd, $J=8.4$ and $1.9 \mathrm{~Hz}, 1 \mathrm{H}), 4.18(\mathrm{~m}, 1 \mathrm{H}), 3.67$ (dd, $J=4.9$ and $1.4 \mathrm{~Hz}, 1 \mathrm{H}), 2.28$ (m, 1H), 1.94-1.83 (complex m, 4H), 1.68 (m, 2H), 1.54 (s, 3H), 1.45 (m, 1H), 1.39 (s, 3H), 1.35-1.15 (complex m, 3H); ${ }^{13} \mathrm{C}$ NMR (101 MHz, $\left.\mathrm{CDCl}_{3}\right) \delta 131.3,127.2,108.5,76.0,75.8$, 67.8, 37.8, 32.6, 30.6, 28.6, 26.0, 25.5, 24.5, 19.3, 17.2; IR (KBr) v $v_{\max } 3399$, 2925, 2862, 1469, 1380, 1259, 1207, 1164, 1064, 1031, 876, 807, $518 \mathrm{~cm}^{-1}$; MS (EI, $70 \mathrm{eV)} \mathrm{m/z} 250$ $\left(\mathrm{M}^{+\bullet}, 5 \%\right), 235$ [(M-CH $\left.\left.3^{\bullet}\right)^{+}, 85\right], 149$ (100); HREIMS Found: $\mathrm{M}^{+\bullet}$, 250.1562. $\mathrm{C}_{15} \mathrm{H}_{22} \mathrm{O}_{3}$ requires $\mathrm{M}^{+\bullet}, 250.1569$. 


\section{Compound 14}

A magnetically stirred solution of allylic alcohol $30(71 \mathrm{mg}, 0.28 \mathrm{mmol})$ in anhydrous dichloromethane $\left(7.0 \mathrm{~mL}\right.$ ) maintained at $22{ }^{\circ} \mathrm{C}$ under a nitrogen atmosphere was treated with molecular sieves (75 mg of powered, anhydrous $4 \AA$ material), pyridinium dichromate (PDC $117 \mathrm{mg}, 0.31 \mathrm{mmol})$ then acetic acid $(95 \mu \mathrm{L}, 16.6 \mathrm{mmol})$. The resulting mixture was stirred at $22{ }^{\circ} \mathrm{C}$ for $1.5 \mathrm{~h}$ then treated with Celite ${ }^{\mathrm{TM}}(1.50 \mathrm{~g})$ before being filtered through a sinteredglass funnel. The filtrate thus obtained was concentrated under reduced pressure and the ensuing residue subjected to flash column chromatography (silica, $1: 4 \mathrm{v} / \mathrm{v}$ ethyl acetate/hexane elution) to afford, after concentration of the appropriate fractions $\left(R_{\mathrm{f}}=0.5\right.$ in 3:7 v/v ethyl acetate/hexane), enone 14 (67 mg, 97\%) as a white, crystalline solid, m.p. = 104-107 ${ }^{\circ} \mathrm{C},[\alpha]_{\mathrm{D}}=+59.05\left(c=1.0, \mathrm{CHCl}_{3}\right) .{ }^{1} \mathrm{H}$ NMR $\left(800 \mathrm{MHz}, \mathrm{CDCl}_{3}\right) \delta 6.83(\mathrm{ddd}, J=$ 10.2, 5.8 and $2.2 \mathrm{~Hz}, 1 \mathrm{H}$ ), 5.94 (m, 1H), 4.15 (dd, $J=8.1$ and $1.7 \mathrm{~Hz}, 1 \mathrm{H}$ ), 4.10 (ddd, $J=8.1$, 3.3 and $1.4 \mathrm{~Hz}, 1 \mathrm{H}), 2.55$ (m, 1H), 2.32 (m, 1H), 1.96 (m, 2H), 1.87-1.78 (complex m, 3H), 1.58 (s, 3H), 1.42 (s, 3H), 1.35-1.20 (complex m, 3H); $\left.{ }^{13} \mathrm{C} \mathrm{NMR} \mathrm{(201} \mathrm{MHz,} \mathrm{CDCl}_{3}\right) \delta 202.6$, 147.6, 129.5, 108.9, 76.1, 76.0, 46.0, 32.5, 30.5, 29.9, 28.8, 26.2, 24.3, 18.9, 17.0; IR (KBr) $v_{\max } 2923,2852,1737,1673,1465,1379,1263,1207,1166,1121,1074,1015,963,918$, 879, 797, 745, $646 \mathrm{~cm}^{-1}$; MS (EI, $\left.70 \mathrm{eV}\right) \mathrm{m} / \mathrm{z} 248\left(\mathrm{M}^{+\bullet}, 22 \%\right), 233\left[\left(\mathrm{M}-\mathrm{CH}_{3}\right)^{+}, 100\right]$; HREIMS Found: $\left(\mathrm{M}-\mathrm{CH}_{3} \bullet\right)^{+}$, 233.1179. $\mathrm{C}_{15} \mathrm{H}_{20} \mathrm{O}_{3}$ requires $\left(\mathrm{M}-\mathrm{CH}_{3} \bullet\right)^{+}, 233.1178$.

\section{Compound 31}

A magnetically stirred slurry of dry copper(I) iodide (389 mg, $2.0 \mathrm{mmol}$ ) in distilled diethyl ether $(17 \mathrm{~mL})$ maintained at $-78{ }^{\circ} \mathrm{C}$ under nitrogen was treated, dropwise, with methyl lithium ( $2.5 \mathrm{~mL}$ of a $1.6 \mathrm{M}$ solution in diethyl ether, $4.0 \mathrm{mmol}$ ). The resulting light-tan colored solution was stirred for $0.33 \mathrm{~h}$ at this temperature then a solution of the enone 23 (248 mg, $1.0 \mathrm{mmol}$ ) in diethyl ether ( $3.5 \mathrm{~mL}$ ) was added, via syringe pump, over $0.17 \mathrm{~h}$. The ensuing bright-yellow reaction mixture was stirred for $1 \mathrm{~h}$ at $-78{ }^{\circ} \mathrm{C}$ then quenched with $\mathrm{NH}_{4} \mathrm{Cl}$ solution (15 $\mathrm{mL}$ of a saturated aqueous solution). The separated aqueous layer was extracted with diethyl ether $(3 \times 25 \mathrm{~mL})$ and the combined organic phases washed with brine $\left(1 \times 10 \mathrm{~mL}\right.$ ) before being dried $\left(\mathrm{Na}_{2} \mathrm{SO}_{4}\right)$, filtered and concentrated under reduced pressure to give a clear, light-yellow oil. Subjection of this oil to flash column chromatography (silica, $3: 7 \mathrm{v} / \mathrm{v}$ ethyl acetate/hexane elution) and concentration of the relevant fractions $\left(R_{\mathrm{f}}=0.5\right)$ 
afforded compound 31 (187 mg, 71\%) as a white, crystalline solid, m.p. $=147-154{ }^{\circ} \mathrm{C},[\alpha]_{\mathrm{D}}$ $=+19.5\left(c=1.0, \mathrm{CHCl}_{3}\right) .{ }^{1} \mathrm{H} \mathrm{NMR}\left(400 \mathrm{MHz}, \mathrm{CDCl}_{3}\right) \delta 4.13(\mathrm{ddd}, J=8.4,3.8$ and $1.3 \mathrm{~Hz}$, 1H), 3.98 (dd, $J=8.4$ and $2.0 \mathrm{~Hz}, 1 \mathrm{H}$ ), 2.67 (dd, $J=14.3$ and $6.2 \mathrm{~Hz}, 1 \mathrm{H}$ ), 2.42-2.26 (complex m, 2H), 2.12-1.59 (complex m, 9H), 1.51 (s, 3H), 1.35 (s, 3H), 1.14 (m, 1H), 0.94 (d, $J=7.3 \mathrm{~Hz}, 3 \mathrm{H}) ;{ }^{13} \mathrm{C}$ NMR $\left(101 \mathrm{MHz}, \mathrm{CDCl}_{3}\right) \delta 211.5,108.4,76.7,75.7,46.2,45.0,36.3$, 36.2, 31.1, 31.0, 28.8, 25.9, 24.3, 19.3, 19.1, 15.8; IR (KBr) v $v_{\max } 2998$, 2973, 2960, 2925, 2863, 1705, 1466, 1454, 1430, 1417, 1382, 1374, 1288, 1266, 1203, 1145, 1080, 1064, 1025, 993, 972, 939, 908, 878, 832, 733, 671, 648, 601, $515 \mathrm{~cm}^{-1}$; MS (EI, 70 eV) m/z 249 [(M$\left.\mathrm{CH}_{3}\right)^{+}, 100 \%$ ]; HREIMS Found: $\left(\mathrm{M}-\mathrm{CH}_{3}\right)^{+}$, 249.1491. $\mathrm{C}_{16} \mathrm{H}_{24} \mathrm{O}_{3}$ requires $\left(\mathrm{M}-\mathrm{CH}_{3}\right)^{+}$, 249.1491.

\section{Compounds 15 and 32}

Step i: A magnetically stirred solution of ketone 31 (157 mg, $0.59 \mathrm{mmol}$ ) in dry dichloromethane $(7.5 \mathrm{~mL})$ maintained under an atmosphere of nitrogen was cooled to $0{ }^{\circ} \mathrm{C}$ then treated with trimethylamine $(660 \mu \mathrm{L}, 7.1 \mathrm{mmol})$ and TMSOTf $(600 \mu \mathrm{L}, 3.54 \mathrm{mmol})$. The resulting mixture was stirred at $0{ }^{\circ} \mathrm{C}$ for $1.5 \mathrm{~h}$, after which time it was warmed to $22{ }^{\circ} \mathrm{C}$ and stirred for a further $0.5 \mathrm{~h}$ before being diluted with hexane $(65 \mathrm{~mL})$. The resulting solution was washed with $\mathrm{NaHCO}_{3}(1 \times 15 \mathrm{~mL}$ of a saturated aqueous solution) and brine (1 x $10 \mathrm{~mL}$ ) then dried $\left(\mathrm{MgSO}_{4}\right)$, filtered and concentrated under reduced pressure to give a clear, colorless oil that is presumed to be comprising of the anticipated mixture of silyl enol ethers.

Step ii: The oil obtained from step $i$ was dissolved in DMSO $(500 \mathrm{~mL})$ and the resulting solution treated with IBX (2.21 mL of a $0.4 \mathrm{M}$ solution in DMSO, $0.89 \mathrm{mmol})$ and MPO (2.21 mL of a $0.4 \mathrm{M}$ solution in DMSO, $0.89 \mathrm{mmol}$ ). The ensuing mixture was at $22{ }^{\circ} \mathrm{C}$ for $16 \mathrm{~h}$ while being protected from light then quenched with $\mathrm{NaHCO}_{3}(7.5 \mathrm{~mL}$ of a saturated aqueous solution) before being extracted with ethyl acetate $(4 \times 10 \mathrm{~mL})$. The combined organic extracts were washed with brine $(1 \times 10 \mathrm{~mL})$ then dried $\left(\mathrm{MgSO}_{4}\right)$, filtered and concentrated under reduced pressure to give a clear, light-yellow oil. Subjection of this material to flash column chromatography (silica, 1:9 v/v ethyl acetate/hexane elution) gave, after concentration of the relevant fractions $\left(R_{\mathrm{f}}=0.5\right.$ in 2:8 v/v ethyl acetate/hexane), a $c a$. 2:3 mixture of enones 15 and 32 (122 mg, 79\% combined yield) as white, crystalline and 
chromatographically inseparable solid, m.p. $=80-116{ }^{\circ} \mathrm{C} .{ }^{1} \mathrm{H}$ NMR $\left(400 \mathrm{MHz}, \mathrm{CDCl}_{3}\right) \delta$ 5.93 (m, 2/5H), 5.80 (broad s, 3/5H), 4.15-4.10 (complex m, 1H), 3.90 (m, 3/5H), 3.48 (broad s, 2/5H), 2.55-2.20 (complex m, 4H), 2.10 (m, 1H), 2.02 (s, 1.8H), 2.00-1.75 (complex m, 4H), 1.57 (s, 4.2H), 1.50-1.15 (complex m, 3.8H), 1.08 (d, $J=8.0 \mathrm{~Hz}, 1.2 \mathrm{H}$ ); ${ }^{13} \mathrm{C}$ NMR $\left(101 \mathrm{MHz}, \mathrm{CDCl}_{3}\right) \delta$ 198.8, 198.6, 167.4, 165.5, 127.6, 126.4, 109.4, 108.6, 78.1, 76.0, 75.9, 73.0, 42.3, 41.7, 40.9, 40.6, 35.1, 33.4, 32.6, 31.0, 30.5, 29.4, 26.2, 26.1, 24.5, 24.4, 22.7, 22.3, 19.1, 18.3, 16.8 (one resonance obscured or overlapping); IR (KBr) $v_{\max }$ 2939, 2882, 1713, 1675, 1372, 1259, 1203, 1063, 875, $514 \mathrm{~cm}^{-1}$; MS (EI, $70 \mathrm{eV}$ ) m/z 262 $\left(\mathrm{M}^{+\bullet}, 60\right), 247$ (45), 85 (95), 83 (92), 51 (100); HREIMS Found: $\mathrm{M}^{+\bullet}$, 262.1565. $\mathrm{C}_{16} \mathrm{H}_{22} \mathrm{O}_{3}$ requires $\mathrm{M}^{+\bullet}, 262.1569$.

\section{Compound 33}

A magnetically stirred solution of the previously reported and epimeric mixture of alcohols ${ }^{5}$ derived from compound 7 (187.6 $\mathrm{mg}, 0.75 \mathrm{mmol})$ in dichloromethane $(10 \mathrm{~mL})$ maintained at $22{ }^{\circ} \mathrm{C}$ was treated, in portions, with the DMP (353 mg, $0.83 \mathrm{mmol}$ ). The ensuing mixture was stirred for $2.5 \mathrm{~h}$ then diluted with dichloromethane $(10 \mathrm{~mL})$ and the resulting solution washed with $\mathrm{Na}_{2} \mathrm{~S}_{2} \mathrm{O}_{3}$ (1 x $15 \mathrm{~mL}$ of a saturated aqueous solution) then $\mathrm{NaHCO}_{3}(1 \times 15 \mathrm{~mL}$ of a saturated aqueous solution). The combined aqueous phases were extracted with dichloromethane ( $3 \times 15 \mathrm{~mL}$ ) and the combined organic phases were washed with brine (1 x $15 \mathrm{~mL}$ ) then dried $\left(\mathrm{Na}_{2} \mathrm{SO}_{4}\right)$, filtered and concentrated under reduced pressure to give a clear, colorless oil. Subjection of this material to flash column chromatography (silica, 3:7 v/v ethyl acetate/hexane elution) and concentration of appropriate fractions $\left(R_{\mathrm{f}}=0.4\right)$ afforded compound 33 (140 mg, 75\%) as a white, crystalline solid, m.p. $=122-124{ }^{\circ} \mathrm{C},[\alpha]_{\mathrm{D}}=+42.5$ $\left(c=1.0, \mathrm{CDCl}_{3}\right) .{ }^{1} \mathrm{H} \mathrm{NMR}\left(400 \mathrm{MHz}, \mathrm{CDCl}_{3}\right) \delta 6.26(\mathrm{~m}, 1 \mathrm{H}), 6.04(\mathrm{~m}, 1 \mathrm{H}), 4.20(\mathrm{~m}, 1 \mathrm{H})$, 3.77 (m, 1H), 2.82 (broad s, 1H), 2.52-2.28 (complex m, 3H), 2.19 (m, 1H), 1.99 (m, 1H), 1.77-1.60 (complex m, 3H), 1.31 (s, 3H), 1.25 (s, 3H), 0.85 (m, 1H); ${ }^{13} \mathrm{C}$ NMR (101 MHz, $\left.\mathrm{CDCl}_{3}\right) \delta 211.1,132.4,130.9,108.8,83.5,79.3,47.1,41.7,38.1,36.7,34.7,31.9,29.6,25.6$, 25.1; IR (KBr) $v_{\max }$ 2986, 2938, 2869, 1714, 1455, 1431, 1379, 1366, 1266, 1245, 1206, 1110, 1165, 1065, 1042, 1009, 986, 954, 879, 841, 726, 699, 525, $514 \mathrm{~cm}^{-1}$; MS (ESI, +ve) m/z 303 (98\%), $271\left[(\mathrm{M}+\mathrm{Na})^{+}, 100\right]$; HRESMS Found: $(\mathrm{M}+\mathrm{Na})^{+}, 271.1312 . \mathrm{C}_{15} \mathrm{H}_{2} \mathrm{O}_{3}$ requires $(\mathrm{M}+\mathrm{Na})^{+}, 271.1310$. 


\section{Compounds 34 and 35}

A magnetically stirred solution of ketone $33(248 \mathrm{mg}, 1.0 \mathrm{mmol})$ in dry dichloromethane $(13.0 \mathrm{~mL})$ maintained under an atmosphere of nitrogen was cooled to $0{ }^{\circ} \mathrm{C}$ then treated with trimethylamine (975 $\mu \mathrm{L}, 10.5 \mathrm{mmol})$ and TMSOTf $(1.03 \mathrm{~mL}, 6.0 \mathrm{mmol})$. The mixture thus obtained was stirred at $0{ }^{\circ} \mathrm{C}$ for $1 \mathrm{~h}$ then warmed to $22{ }^{\circ} \mathrm{C}$ and stirred at this temperature for a further $0.5 \mathrm{~h}$ before being diluted hexane $(125 \mathrm{~mL})$, washed with $\mathrm{NaHCO}_{3}(1 \mathrm{x} 25 \mathrm{~mL}$ of a saturated aqueous solution) and brine $(1 \times 15 \mathrm{~mL})$ then dried $\left(\mathrm{Na}_{2} \mathrm{SO}_{4}\right)$ filtered and concentrated under reduced pressure to give a clear, light-yellow oil. This oil was dissolved in DMSO (1.0 mL) and the resulting solution treated with a solution of IBX (3.95 mL of 0.4 M solution in DMSO, $1.58 \mathrm{mmol}$ ) and MPO (3.95 mL of 0.4 M solution in DMSO, 1.58 mmol) then stirred at $22{ }^{\circ} \mathrm{C}$ for $16 \mathrm{~h}$ while being protected from light. After this time the reaction mixture was quenched with $\mathrm{NaHCO}_{3}(15 \mathrm{~mL}$ of a saturated aqueous solution) and extracted with ethyl acetate $(5 \times 15 \mathrm{~mL})$. The combined organic extracts were washed with brine (1 x $25 \mathrm{~mL}$ ) before being dried $\left(\mathrm{Na}_{2} \mathrm{SO}_{4}\right)$, filtered and concentrated under reduced pressure to give a clear, light-yellow oil. Subjection of this oil to flash column chromatography (silica 1:9 v/v ethyl acetate/hexane elution) afforded two fractions, $\mathrm{A}$ and $\mathrm{B}$. Concentration of fraction A $\left[R_{\mathrm{f}}=0.3(7)\right.$ in 3:7 v/v ethyl acetate/ hexane] afforded compound 34 (54 mg, 21\%) as a white, crystalline solid, m.p $=146-148{ }^{\circ} \mathrm{C},[\alpha]_{\mathrm{D}}=+10.7(\mathrm{c}=1.0$, $\left.\mathrm{CHCl}_{3}\right) .{ }^{1} \mathrm{H} \mathrm{NMR}\left(400 \mathrm{MHz}, \mathrm{CDCl}_{3}\right) \delta 6.31(\mathrm{t}, J=7.2 \mathrm{~Hz}, 1 \mathrm{H}), 5.96(\mathrm{~d}, J=2.0 \mathrm{~Hz}, 1 \mathrm{H})$, 5.83 (d, $J=7.2 \mathrm{~Hz}, 1 \mathrm{H}), 4.33$ (m, 1H), 4.19 (dd, $J=7.2$ and $1.3 \mathrm{~Hz}, 1 \mathrm{H}), 3.07$ (m, 1H), 2.532.22 (complex m, 6H), 1.35 (s, 3H), 1.29 (s, 3H); $\left.{ }^{13} \mathrm{C} \mathrm{NMR} \mathrm{(101} \mathrm{MHz,} \mathrm{CDCl}_{3}\right) \delta 197.9$, 162.3, 133.2, 132.2, 125.9, 109.9, 78.9, 78.6, 44.5, 35.8, 33.7, 31.5, 27.1, 25.6, 25.2; IR (KBr) $v_{\max } 2989,2937,2901,1670,1629,1452,1423,1380,1331,1266,1207,1162,1075$, 1045, 974, 918, 875, 793, 726, $703 \mathrm{~cm}^{-1}$; MS (ESI, +ve) m/z 269 [(M+Na) , 100\%], 247 $\left[(\mathrm{M}+\mathrm{H})^{+}, 22\right]$; HRESMS Found: $(\mathrm{M}+\mathrm{H})^{+}, 247.1327 . \mathrm{C}_{15} \mathrm{H}_{18} \mathrm{O}_{3}$ requires $(\mathrm{M}+\mathrm{H})^{+}, 247.1334$.

Concentration of fraction $\mathrm{B}\left[R_{\mathrm{f}}=0.3(5)\right.$ in $3: 7 \mathrm{v} / \mathrm{v}$ ethyl acetate/ hexane] afforded compound $35(162 \mathrm{mg}, 65 \%)$ as a white, crystalline solid, m.p $=133-135{ }^{\circ} \mathrm{C},[\alpha]_{\mathrm{D}}=+13.9(c=1.0$, $\mathrm{CHCl}_{3}$ ). ${ }^{1} \mathrm{H}$ NMR (400 MHz, $\left.\mathrm{CDCl}_{3}\right) \delta 7.29(\mathrm{dd}, J=10.0$ and $1.5 \mathrm{~Hz}, 1 \mathrm{H}), 6.33(\mathrm{t}, J=8.0$ Hz, 1H), 6.09 (d, $J=10.0 \mathrm{~Hz}, 1 \mathrm{H}$ ), 5.75 (d, $J=8.0 \mathrm{~Hz}, 1 \mathrm{H}), 4.27$ (m, 1H), 3.93 (dd, $J=8.0$ and $1.8 \mathrm{~Hz}, 1 \mathrm{H}$ ), 2.90 (broad s, 1H), 2.36 (dd, $J=16.2$ and $4.3 \mathrm{~Hz}, 1 \mathrm{H}$ ), 2.09 (ddd, $J=16.2$, 13.8 and $1.5 \mathrm{~Hz}, 1 \mathrm{H}), 1.93$ (m, 1H), 1.73 (m, 1H), 1.36 (d, $J=1.5 \mathrm{~Hz}, 3 \mathrm{H}), 1.29$ (d, $J=1.5$ 
Hz, 3H), 0.95-0.88 (complex m, 1H); $\left.{ }^{13} \mathrm{C} \mathrm{NMR} \mathrm{(101} \mathrm{MHz,} \mathrm{CDCl}_{3}\right) \delta$ 199.5, 152.0, 133.1, 129.7, 128.6, 109.1, 80.8, 78.6, 44.3, 43.4, 34.9, 33.7, 28.7, 25.6, 25.1; IR (KBr) v $v_{\max } 2979$, 2937, 2892, 1681, 1456, 1415, 1381, 1373, 1265, 1207, 1165, 1094, 1066, 996, 884, 828, 778, 726, 703, 647, 542, $514 \mathrm{~cm}^{-1}$; MS (ESI, +ve) m/z 301 (100\%), 269 [(M+Na) $\left.{ }^{+}, 50\right], 247$ $\left[(\mathrm{M}+\mathrm{H})^{+}, 51\right]$; HRESMS Found: $(\mathrm{M}+\mathrm{H})^{+}, 247.1330 . \mathrm{C}_{15} \mathrm{H}_{18} \mathrm{O}_{3}$ requires $(\mathrm{M}+\mathrm{H})^{+}$, 247.1334.

\section{Compounds 37, 38 and 39}

A magnetically stirred solution of enone 36 (125 mg, $0.5 \mathrm{mmol})$ in THF/HMPA (7.5 mL of a 4:1 v/v mixture) maintained under an argon atmosphere was cooled to $-78{ }^{\circ} \mathrm{C}$ then treated, dropwise, with KHMDS (1.25 $\mathrm{mL}$ of a $0.5 \mathrm{M}$ solution in toluene, $0.63 \mathrm{mmol})$. The ensuing mixture was allowed to stir at $-78{ }^{\circ} \mathrm{C}$ for $0.3 \mathrm{~h}$ before being treated, dropwise, with iodomethane $(225 \mu \mathrm{L}, 3.5 \mathrm{mmol})$ then stirred at $-78{ }^{\circ} \mathrm{C}$ for $0.3 \mathrm{~h}$. The ensuing mixture was allowed to warm to $0^{\circ} \mathrm{C}$ over a period of $0.5 \mathrm{~h}$ before being quenched with $\mathrm{NaHCO}_{3}(10 \mathrm{~mL}$ of saturated aqueous solution) and extracted with ethyl acetate (3 x $15 \mathrm{~mL})$. The combined organic phases were dried $\left(\mathrm{MgSO}_{4}\right)$, filtered, and concentrated under reduced pressure and the clear, light-yellow oil thus obtained subjected semi-preparative HPLC (see General Experimental Procedures above for details) and so affording three fractions, A-C.

Concentration of fraction A $\left(R_{\mathrm{t}}=6.3 \mathrm{~min}\right)$ afforded compound 38 (66 mg, 51\%) as a white, crystalline solid, m.p. $=118-121^{\circ} \mathrm{C},[\alpha]_{\mathrm{D}}=+66.9\left(c=1.0, \mathrm{CHCl}_{3}\right) .{ }^{1} \mathrm{H}$ NMR $(400 \mathrm{MHz}$, $\left.\mathrm{CDCl}_{3}\right) \delta 5.93(\mathrm{t}, J=2.0 \mathrm{~Hz}, 1 \mathrm{H}), 4.23$ (dd, $J=8.1$ and $\left.1.5 \mathrm{~Hz}, 1 \mathrm{H}\right), 4.13(\mathrm{~m}, 1 \mathrm{H}), 2.60-2.46$ (complex m, 2H), 2.35 (m, 1H), 2.15 (dd, $J=14.0$ and $5.4 \mathrm{~Hz}, 1 \mathrm{H}$ ), 2.11-1.99 (complex m, 2H), 1.91 (m, 1H), 1.55 (s, 3H), 1.44 (s, 3H), 1.40-1.23 (complex m, 3H), 1.11 (d, $J=6.6$ $\mathrm{Hz}, 3 \mathrm{H}) ;{ }^{13} \mathrm{C} \mathrm{NMR}\left(101 \mathrm{MHz}, \mathrm{CDCl}_{3}\right) \delta 200.5,164.7,126.3,109.6,75.5,73.9,38.3,37.6$, 36.7, 31.4, 30.4, 26.0, 25.3, 24.5, 18.9, 14.8; IR (KBr) vmax 2963, 2937, 2920, 2872, 1668, 1631, 1460, 1374, 1261, 1209, 1164, 1078, 1059, 1028, 921, 879, 848, 830, $518 \mathrm{~cm}^{-1}$; MS

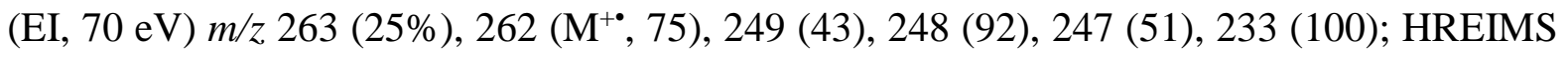
Found: $\mathrm{M}^{+\bullet}$, 262.1566. $\mathrm{C}_{16} \mathrm{H}_{22} \mathrm{O}_{3}$ requires $\mathrm{M}^{+\bullet}$, 262.1566.1569.

Concentration of fraction $\mathrm{B}\left(R_{\mathrm{t}}=6.7 \mathrm{~min}\right)$ afforded compound 37 (30 mg, 23\%) as a white, crystalline solid, m.p. $=153-159{ }^{\circ} \mathrm{C},[\alpha]_{\mathrm{D}}=+31.5\left(c=1.0, \mathrm{CHCl}_{3}\right) \cdot{ }^{1} \mathrm{H}$ NMR $(400 \mathrm{MHz}$, $\left.\mathrm{CDCl}_{3}\right) \delta 5.96(\mathrm{t}, J=2.0 \mathrm{~Hz}, 1 \mathrm{H}), 4.28$ (dd, $J=8.2$ and $\left.4.2 \mathrm{~Hz}, 1 \mathrm{H}\right), 3.80$ (dd, $J=8.2$ and 1.9 Hz, 1H), 2.52 (m, 1H), 2.41 (m, 1H), 2.34-2.18 (complex m, 2H), 2.01-1.87 (complex m, 
3H), 1.62-1.59 (complex m, 3H), 1.57 (s, 3H), 1.38 (s, 3H), 1.10 (d, $J=6.7 \mathrm{~Hz}, 3 \mathrm{H}) ;{ }^{13} \mathrm{C}$ NMR (101 MHz, $\left.\mathrm{CDCl}_{3}\right) \delta$ 200.8, 163.8, 126.0, 109.4, 79.3, 75.8, 39.3, 39.0, 36.6, 32.6, 30.1, 25.9, 24.4, 21.8, 18.8, 14.8; IR (KBr) $v_{\max }$ 2963, 2932, 2907, 2872, 1673, 1634, 1459, 1375, 1263, 1205, 1152, 1068, 1047, 978, 945, 877, $848 \mathrm{~cm}^{-1}$; MS (ESI, +ve) m/z 547 (47\%), 317 (50), 285 (100), 263 (70); HREIMS Found: $\mathrm{M}^{+\bullet}$, 262.1568. $\mathrm{C}_{16} \mathrm{H}_{22} \mathrm{O}_{3}$ requires $\mathrm{M}^{+\bullet}$, 262.1566.1569.

Concentration of fraction C ( $\left.R_{\mathrm{t}}=7.1 \mathrm{~min}\right)$ gave compound $39(9 \mathrm{mg}, 7 \%)$ as a white, crystalline solid, m.p. $=160-162{ }^{\circ} \mathrm{C},[\alpha]_{\mathrm{D}}=+15.4\left(c=1.0, \mathrm{CHCl}_{3}\right) .{ }^{1} \mathrm{H}$ NMR $(400 \mathrm{MHz}$, $\left.\mathrm{CDCl}_{3}\right) \delta 6.05(\mathrm{~d}, J=6.9 \mathrm{~Hz}, 1 \mathrm{H}), 4.04(\mathrm{~m}, 1 \mathrm{H}), 3.87$ (dd, $J=8.4$ and $\left.1.7 \mathrm{~Hz}, 1 \mathrm{H}\right), 2.77(\mathrm{~m}$, 1H), 2.50-2.39 (complex m, 2H), 2.17-2.01 (complex m, 2H), 1.95-1.83 (complex m, 2H), 1.51 (s, 3H), 1.32 (s, 3H), 1.24 (s, 3H), 1.20 (s, 3H), 1.05 (complex m, 2H); ${ }^{13} \mathrm{C}$ NMR (101 $\left.\mathrm{MHz}, \mathrm{CDCl}_{3}\right) \delta 213.9,149.7,125.8,112.1,78.2,75.5,48.5,40.7,35.4,35.2,26.8,26.6$, 26.2, 25.5, 24.9, 24.7, 19.2; IR (KBr) $v_{\max } 2978,2937,2902,2871,1713,1462,1379,1263$, 1207, 1162, 1064, 1088, 973, 877, $836 \mathrm{~cm}^{-1}$; MS (ESI, +ve) m/z 413 (100\%), 331 (75), 299 (52), 277 (39); HRESMS Found: $(\mathrm{M}+\mathrm{Na})^{+}$, 299.1622. $\mathrm{C}_{17} \mathrm{H}_{24} \mathrm{O}_{3}$ requires $(\mathrm{M}+\mathrm{Na})^{+}$, 299.1623.

\section{Compound 40}

A magnetically stirred solution of enone 38 (195 mg, $0.75 \mathrm{mmol}$ ) in diethyl ether/t-butanol (5.0 $\mathrm{mL}$ of a $1: 1 \mathrm{v} / \mathrm{v}$ mixture) maintained at $0{ }^{\circ} \mathrm{C}$ under a nitrogen atmosphere was treated, dropwise, with $t$-BuOK (1.5 mL of a $1.0 \mathrm{M}$ solution in $t$-butanol, $1.5 \mathrm{mmol})$. The resulting mixture was stirred at $0{ }^{\circ} \mathrm{C}$ for $0.33 \mathrm{~h}$ before being treated, dropwise, with a solution of $t$ butyl acrylate $(223 \mu \mathrm{L}, 1.49 \mathrm{mmol})$ in dry diethyl ether $(4.5 \mathrm{~mL})$. The ensuing mixture was allowed to stir for another $0.4 \mathrm{~h}$ at $0{ }^{\circ} \mathrm{C}$ before being quenched with $\mathrm{NH}_{4} \mathrm{Cl}(15 \mathrm{~mL}$ of a saturated aqueous solution) then extracted with ethyl acetate ( $3 \times 10 \mathrm{~mL})$. The combined organic phases were washed with brine $(1 \times 7 \mathrm{~mL})$ then dried $\left(\mathrm{MgSO}_{4}\right)$, filtered and concentrated under reduced pressure. The light-yellow oil thus obtained was subjected to flash column chromatography (silica, 1:9 v/v ethyl acetate/hexane elution) to afford, after concentration of the relevant fractions ( $R_{\mathrm{f}}=0.5$ in $3: 7 \mathrm{v} / \mathrm{v}$ ethyl acetate/hexane), a clear, colorless oil. ${ }^{1} \mathrm{H}$ NMR spectroscopic analysis of this material suggested it was comprised of a $>$ 6:1 mixture of esters $\mathbf{4 0}$ and $\mathbf{4 1}$. Subjection of this material to semi-preparative HPLC (see 
General Experimental Procedures above for details) and concentration of the appropriate fractions $\left(R_{\mathrm{t}}=10.7 \mathrm{~min}\right)$ afforded compound $40(167 \mathrm{mg}, 57 \%)$ as a white foam, $[\alpha]_{\mathrm{D}}=$ $+10.3\left(c=1.0, \mathrm{CHCl}_{3}\right) .{ }^{1} \mathrm{H}$ NMR $\left(400 \mathrm{MHz}, \mathrm{CDCl}_{3}\right) \delta 4.14(\mathrm{dd}, J=8.2$ and $3.7 \mathrm{~Hz}, 1 \mathrm{H})$, 3.97 (d, $J=8.2 \mathrm{~Hz}, 1 \mathrm{H}$ ), 2.64-1.60 (complex m, 12H), 1.53 (s, 1H), 1.42 (s, 9H), 1.42-1.24 (complex m, 9H) (one resonance obscured or overlapping); ${ }^{13} \mathrm{C} \mathrm{NMR}\left(101 \mathrm{MHz}, \mathrm{CDCl}_{3}\right) \delta$ 201.9, 173.0, 156.5, 132.6, 109.2, 80.3, 78.4, 75.5, 42.6, 39.9, 37.4, 34.2, 33.8, 31.1, 30.5, 30.0, 28.3, 26.1, 25.9, 25.1, 24.3; IR (KBr) $v_{\max }$ 2977, 2934, 1728, 1674, 1458, 1368, 1296, 1260, 1207, 1153, 1119, 1066, 975, 876, 848, $756 \mathrm{~cm}^{-1}$; MS (EI, $\left.70 \mathrm{eV}\right) \mathrm{m} / \mathrm{z} 390\left(\mathrm{M}^{+\bullet}, 5 \%\right)$, 375 (25), 334 (90), 317 (56), 203 (95), 159 (80), 57 (100); HRESMS Found: (M+H) , 391.2489. $\mathrm{C}_{23} \mathrm{H}_{34} \mathrm{O}_{5}$ requires $(\mathrm{M}+\mathrm{H})^{+}, 391.2484$.

\section{Compound 43}

A magnetically stirred solution of acetonide $42(285 \mathrm{mg}, 0.72 \mathrm{mmol})$ in THF/methanol/water ( $9 \mathrm{~mL}$ of 3:1:3 v/v/v mixture) was treated with DOWEX-50 resin (350 $\mathrm{mg}$ of material that had been rinsed successively with $1 \mathrm{M}$ aqueous hydrochloric acid, water, saturated sodium bicarbonate solution and water). The resulting suspension was heated at $65^{\circ} \mathrm{C}$ for $36 \mathrm{~h}$ then cooled, filtered and the solids thus retained rinsed with dichloromethane ( $3 \times 25 \mathrm{~mL})$ then methanol ( $3 \times 15 \mathrm{~mL})$. The combined filtrates were dried $\left(\mathrm{MgSO}_{4}\right)$, filtered and concentrated under reduced pressure and the resulting clear, colorless oil was subjected to flash column chromatography (silica, 1:9 $\rightarrow$ 3:7 v/v ethyl acetate/hexane gradient elution) to afford two fractions, A and B.

Concentration of fraction A ( $R_{\mathrm{f}}=0.6$ in 3:7 $\mathrm{v} / \mathrm{v}$ ethyl acetate/hexane) afforded the starting acetonide 42 (59 mg, 21\% recovery) as a clear, colorless oil that was identical, in all respects, with authentic material.

Concentration of fraction B ( $R_{\mathrm{f}}=0.4$ in 1:1:0.1 $\mathrm{v} / \mathrm{v}$ ethyl acetate/hexane/acetic acid) afforded diol 43 (154 mg, $61 \%$ at $79 \%$ conversion) as a thick, white foam, $[\alpha]_{\mathrm{D}}=+3.5(c=1.0$, $\left.\mathrm{CHCl}_{3}\right) .{ }^{1} \mathrm{H}$ NMR $\left(400 \mathrm{MHz}, \mathrm{CDCl}_{3}\right) \delta 6.82(\mathrm{~d}, J=10.2 \mathrm{~Hz}, 1 \mathrm{H}), 5.88(\mathrm{~d}, J=10.2 \mathrm{~Hz}, 1 \mathrm{H})$, 3.95 (m, 1H), 3.40 (m, 1H), 3.22 (broad s, 1H), 2.63 (broad s, 1H), 2.17 (m, 1H), 2.06-1.85 (complex m, 6H), 1.79-1.59 (complex m, 5H), 1.41 (s, 9H), 1.01 (s, 3H); ${ }^{13} \mathrm{C}$ NMR (101 $\left.\mathrm{MHz}, \mathrm{CDCl}_{3}\right) \delta 203.7,173.2,152.6,126.4,80.6,72.6,67.5,47.3,42.1,39.0,32.8,30.6$, 28.2, 27.2, 25.1, 19.8, 18.2(3), 18.1(9); IR (KBr) $v_{\max } 3280$, 2929, 2912, 1725, 1671, 1450, 
1376, 1366, 1293, 1155, 1143, 1109, 1072, 1054, 1018, 967, 873, 844, 829, $700 \mathrm{~cm}^{-1}$; MS (ESI, +ve) m/z 723 (35\%), $373\left[(\mathrm{M}+\mathrm{Na})^{+}, 75\right], 351\left[(\mathrm{M}+\mathrm{H})^{+}\right.$, 52], 295 (60), 242 (100); HRESMS Found: $(\mathrm{M}+\mathrm{Na})^{+}$, 373. 1991. $\mathrm{C}_{20} \mathrm{H}_{30} \mathrm{O}_{5}$ requires $(\mathrm{M}+\mathrm{Na})^{+}$, 373. 1991.

\section{Compound 44}

A magnetically stirred solution of diol 43 (127 mg, $0.55 \mathrm{mmol})$ in dichloromethane (9 mL) was cooled to $0{ }^{\circ} \mathrm{C}$ then treated with $p-\mathrm{TsOH} \cdot \mathrm{H}_{2} \mathrm{O}$ (260 mg, $\left.1.37 \mathrm{mmol}\right)$. 4-AcetamidoTEMPO (315 mg, $1.37 \mathrm{mmol}$ ) was then added, in portions over $0.5 \mathrm{~h}$, to the reaction mixture that was stirred at $0{ }^{\circ} \mathrm{C}$ for $1 \mathrm{~h}$ and then at $22{ }^{\circ} \mathrm{C}$ for $1 \mathrm{~h}$ before being quenched with $\mathrm{NaHCO}_{3}$ (10 mL of a saturated aqueous solution) and extracted with dichloromethane (5 x $10 \mathrm{~mL})$. The combined organic extracts were dried $\left(\mathrm{MgSO}_{4}\right)$, filtered, and concentrated under reduced pressure to give a clear, light-orange oil. Subjection of this material to flash column chromatography (silica, $1: 4 \mathrm{v} / \mathrm{v}$ ethyl acetate/hexane elution) and concentration of the appropriate fractions ( $R_{\mathrm{f}}=0.6$ in 3:7 v/v ethyl acetate/hexane) afforded acyloin 44 (163 mg, $85 \%)$ as thick, yellow foam, $[\alpha]_{\mathrm{D}}=+95.3,\left(c=1.0, \mathrm{CHCl}_{3}\right) .{ }^{1} \mathrm{H} \mathrm{NMR}\left(400 \mathrm{MHz}, \mathrm{CDCl}_{3}\right) \delta$ 6.87 (d, $J=10.3 \mathrm{~Hz}, 1 \mathrm{H}$ ), 5.95 (d, $J=10.3 \mathrm{~Hz}, 1 \mathrm{H}$ ), 3.31 (s, 1H), 3.28 (s, 1H), 2.60 (broad s, 1H), 2.23 (m, 1H), 2.12-1.81 (complex m, 10H), 1.41 (s, 9H), 1.04 (s, 3H); ${ }^{13} \mathrm{C}$ NMR (101 $\left.\mathrm{MHz}, \mathrm{CDCl}_{3}\right) \delta 216.5,202.6,173.0,149.3,127.1,80.7,79.0,47.4,44.1,42.4,41.9,30.3$, 28.2, 26.4, 25.6, 24.3, 20.5, 18.3; IR (KBr) $v_{\max } 3437,2987,2949,2873,1728,1670,1439$, 1386, 1360, 1294, 1233, 1197, 1173, 1062, 1035, 993, 954, 851, 827, 732, $706 \mathrm{~cm}^{-1}$; MS (ESI, +ve) $\mathrm{m} / \mathrm{z} 371\left[(\mathrm{M}+\mathrm{Na})^{+}, 100 \%\right]$; HRESMS Found: $(\mathrm{M}+\mathrm{Na})^{+}$, 371.1835. $\mathrm{C}_{20} \mathrm{H}_{28} \mathrm{O}_{5}$ requires $(\mathrm{M}+\mathrm{Na})^{+}$, , 371.1834.

\section{Compound 45}

A magnetically stirred solution of acyloin 44 (159 mg, $0.45 \mathrm{mmol})$ in anhydrous dichloromethane $(3.5 \mathrm{~mL})$ was treated with DMAP $(25 \mathrm{mg}, 0.2 \mathrm{mmol})$ then acetic anhydride (51 $\mu \mathrm{L}, 0.54 \mathrm{mmol}$ ) and the ensuing mixture stirred at $22{ }^{\circ} \mathrm{C}$ for $3.5 \mathrm{~h}$. The reaction mixture was then diluted with dichloromethane $(10 \mathrm{~mL})$ before being washed with brine $(1 \mathrm{x} 7 \mathrm{~mL})$ then dried $\left(\mathrm{MgSO}_{4}\right)$, filtered and concentrated under reduced pressure. The resulting lightyellow oil was subjected to flash column chromatography (silica, 1:9 v/v ethyl acetate/hexane) to afford, after concentration of the appropriate fractions $\left(R_{\mathrm{f}}=0.5\right.$ in $2: 3 \mathrm{v} / \mathrm{v}$ 
ethyl acetate/hexane), compound 45 (133 mg, 75\%) as a clear, colorless foam, $[\alpha]_{\mathrm{D}}=+105.0$, $\left(c=1.0, \mathrm{CHCl}_{3}\right) .{ }^{1} \mathrm{H} \mathrm{NMR}\left(400 \mathrm{MHz}, \mathrm{CDCl}_{3}\right) \delta 6.87(\mathrm{~d}, J=10.3 \mathrm{~Hz}, 1 \mathrm{H}), 5.95(\mathrm{~d}, J=10.3$ $\mathrm{Hz}, 1 \mathrm{H}$ ), 4.74 (s, 1H), 2.57 (broad s, 1H), 2.23 (m, 1H), 2.19 (s, 3H), 2.12-1.81 (complex m, 7H), 1.41 (s, 9H), 1.04 (s, 3H); ${ }^{13} \mathrm{C}$ NMR (101 MHz, $\left.\mathrm{CDCl}_{3}\right) \delta$ 209.6, 201.8, 172.9, 169.9, 146.9, 127.6, 80.7, 47.4, 43.7, 42.8, 41.0, 30.2, 29.8, 28.3, 26.4, 24.7, 24.4, 21.3, 20.8, 18.3; IR (KBr) $v_{\max }$ 2929, 1754, 1729, 1675, 1369, 1219, 1152, 1112, 1050, 977, $849 \mathrm{~cm}^{-1}$; MS (ESI, +ve) m/z 445 (100\%), $413\left[(\mathrm{M}+\mathrm{Na})^{+}, 50\right]$; HRESMS Found: $(\mathrm{M}+\mathrm{Na})^{+}, 413.1940$. $\mathrm{C}_{22} \mathrm{H}_{30} \mathrm{O}_{6}$ requires $(\mathrm{M}+\mathrm{Na})^{+}, 413.1940$.

\section{Compound 46}

A solution of freshly prepared $\mathrm{VCl}_{3}{ }^{\bullet}(\mathrm{THF})_{3}(188 \mathrm{mg}, 0.50 \mathrm{mmol})$ in dry toluene $(2.5 \mathrm{~mL})$ maintained at $22{ }^{\circ} \mathrm{C}$ was treated with activated ${ }^{24}$ zinc dust $(33 \mathrm{mg}, 0.50 \mathrm{mmol}$ ) and the resulting mixture irradiated in an ultrasonic bath (Branson Model B2500R-DTH). After 0.33 h a solution of acetate 45 (97 mg, $0.25 \mathrm{mmol})$ in toluene $(1.5 \mathrm{~mL})$ was added to the reaction mixture and sonication continued for $0.66 \mathrm{~h}$. The reaction mixture was then cooled to $22{ }^{\circ} \mathrm{C}$ before being diluted with ethyl acetate $(5.0 \mathrm{~mL})$ and the resulting mixture passed through a short plug of TLC grade silica that was then washed with ethyl acetate ( $3 \mathrm{x} 5 \mathrm{~mL})$. The combined filtrates were washed with water $(1 \times 10 \mathrm{~mL})$ then dried $\left(\mathrm{MgSO}_{4}\right)$, filtered and concentrated under reduced pressure. The yellow oil thus obtained was subjected to flash column chromatography (silica, $1: 4 \mathrm{v} / \mathrm{v}$ ethyl acetate/hexane elution) to afford, after concentration of the relevant fractions $\left(R_{\mathrm{f}}=0.4\right)$, compound $46^{19}(70 \mathrm{mg}, 83 \%)$ as a thick, white foam, $[\alpha]_{\mathrm{D}}=+19.1\left(c=0.5, \mathrm{CHCl}_{3}\right) .{ }^{1} \mathrm{H} \mathrm{NMR}\left(400 \mathrm{MHz}, \mathrm{CDCl}_{3}\right) \delta 6.48(\mathrm{~d}, J=10.1$ Hz, 1H), 5.90 (d, $J=10.1 \mathrm{~Hz}, 1 \mathrm{H}), 2.52$ (broad s, 1H), 2.31 (d, $J=18.1 \mathrm{~Hz}, 1 \mathrm{H}), 2.22$ (m, 2H), 2.10-1.92 (complex m, 9H), 1.67 (m, 1H), 1.43 (s, 9H), 1.03 (s, 3H); ${ }^{13} \mathrm{C}$ NMR (101 $\left.\mathrm{MHz}_{\mathrm{CDCl}}\right) \delta 213.6,202.8,172.8,151.1,126.5,80.5,52.6,47.2,46.0,43.2,38.1,30.1$, 28.1, 26.1, 26.0, 25.6, 23.0, 18.0; IR (KBr) v $v_{\max }$ 2975, 2937, 2875, 2850, 1724, 1673, 1455, 1367, 1257, 1147, 917, 849, 830, 732, 648, $532 \mathrm{~cm}^{-1}$; MS (ESI, +ve) m/z 355 [(M + Na) ${ }^{+}$, 100\%]; HRESMS Found: $(\mathrm{M}+\mathrm{Na})^{+}$, 355.1883. $\mathrm{C}_{20} \mathrm{H}_{28} \mathrm{O}_{4}$ requires $(\mathrm{M}+\mathrm{Na})^{+}$, 355.1885. 


\section{Compounds 49 and 50}

A magnetically stirred solution of enone 48 (551 $\mathrm{mg}, 2.10 \mathrm{mmol})$ in distilled diethyl ether and $t$-butanol (21 $\mathrm{mL}$ of $2: 1 \mathrm{v} / \mathrm{v}$ mixture) maintained at $-10{ }^{\circ} \mathrm{C}$ under an argon atmosphere was treated, dropwise, with $t$-BuOK $(5.25 \mathrm{~mL}$ of a $1.0 \mathrm{M}$ solution in $t-\mathrm{BuOH}, 5.25 \mathrm{mmol})$. The ensuing mixture was stirred at $-10^{\circ} \mathrm{C}$ for $0.2 \mathrm{~h}$ before being treated, via syringe pump, with a solution of methyl acrylate $(1.42 \mathrm{~mL}, 15.75 \mathrm{mmol})$ in diethyl ether $(15 \mathrm{~mL})$. The mixture thus obtained was allowed to stir for $0.3 \mathrm{~h}$ then treated with $\mathrm{NH}_{4} \mathrm{Cl}(15 \mathrm{~mL}$ of a saturated aqueous solution) before being extracted with diethyl ether (5 x $15 \mathrm{~mL}$ ). The combined organic fractions were washed with brine $(1 \times 15 \mathrm{~mL})$ then dried $\left(\mathrm{Na}_{2} \mathrm{SO}_{4}\right)$, filtered and concentrated under reduced pressure. The resulting light-yellow oil was subjected to flash column chromatography (silica, $1: 9 \mathrm{v} / \mathrm{v}$ ethyl acetate/hexane elution) to afford, after concentration of the relevant fractions $\left(R_{\mathrm{f}}=0.4\right.$ in $3: 7 \mathrm{v} / \mathrm{v}$ ethyl acetate/hexane), a clear colorless oil. Subjection of this material to semi-preparative HPLC (see General Experimental Procedures above for details) afforded two fractions, A and B.

Concentration of fraction A ( $\left.R_{\mathrm{t}}=7.5 \mathrm{~min}\right)$ afforded compound 49 (526 $\left.\mathrm{mg}, 72 \%\right)$ as a clear, colorless oil, $[\alpha]_{\mathrm{D}}=+19.5\left(\mathrm{c}=1.0, \mathrm{CHCl}_{3}\right) .{ }^{1} \mathrm{H} \mathrm{NMR}\left(400 \mathrm{MHz}, \mathrm{CDCl}_{3}\right) \delta 6.73(\mathrm{~d}, J=10.2$ $\mathrm{Hz}, 1 \mathrm{H}$ ), 5.88 (d, $J=10.2 \mathrm{~Hz}, 1 \mathrm{H}), 4.18$ (m, 1H), 3.68 (dd, $J=8.1$ and $1.6 \mathrm{~Hz}, 1 \mathrm{H}$ ), 3.65 (s, 3H), 2.29-2.12 (complex m, 3H), 2.05-1.81 (complex m, 3H), 1.74 (td, $J=9.6$ and $1.4 \mathrm{~Hz}$, 1H), 1.68-1.60 (complex m, 3H), 1.54 (s, 3H), 1.35 (s, 3H), 1.33-1.23 (complex m, 2H), 1.19 (s, 3H); ${ }^{13} \mathrm{C}$ NMR (101 MHz, $\left.\mathrm{CDCl}_{3}\right) \delta$ 203.3, 174.0, 152.3, 127.0, 109.4, 79.4, 75.5, 51.8, 47.3, 37.6, 36.6, 30.5, 29.5(9), 29.5(6), 25.9, 24.4, 23.7, 21.3, 19.4, 18.5; IR (KBr) $v_{\max }$ 3025, 2976, 2933, 2873, 1738, 1673, 1469, 1454, 1438, 1381, 1306, 1260, 1207, 1166, 1131, 1116, 1086, 1067, 1033, 992, 931, 875, 826, 811, $709 \mathrm{~cm}^{-1}$; MS (EI, $\left.70 \mathrm{eV}\right) \mathrm{m} / \mathrm{z} 348\left(\mathrm{M}^{+\bullet}\right.$, 20\%), 333(32), 261 (42), 203 (100), 175 (68), 159 (85); HREIMS Found: $\mathbf{M}^{+\bullet}$, 348.1937. $\mathrm{C}_{20} \mathrm{H}_{28} \mathrm{O}_{5}$ requires $\mathrm{M}^{+\bullet}$, 348.1937.

Concentration of fraction B $\left(R_{\mathrm{t}}=9.7 \mathrm{~min}\right)$ afforded compound 50 (100 mg, 14\%) as a clear, colorless and viscous oil, $[\alpha]_{\mathrm{D}}=+11.7\left(c=1.0, \mathrm{CHCl}_{3}\right) .{ }^{1} \mathrm{H} \mathrm{NMR}\left(400 \mathrm{MHz}, \mathrm{CDCl}_{3}\right) \delta 6.72$ (d, $J=10.2 \mathrm{~Hz}, 1 \mathrm{H}), 5.87$ (d, $J=10.2 \mathrm{~Hz}, 1 \mathrm{H}), 4.19$ (m, 1H), 3.66 (m, 1H), 3.64 (s, 3H), 2.30 (m, 1H), 2.14 (m, 1H), 2.06-1.75 (complex m, 6H), 1.65 (m, 4H), 1.55 (s, 3H), 1.25 (s, 3H), 1.05 (s, 3H); ${ }^{13} \mathrm{C}$ NMR (101 MHz, $\left.\mathrm{CDCl}_{3}\right) \delta$ 203.2, 174.2, 152.1, 126.4, 109.4, 79.7, 75.6, 51.8, 47.3, 42.8, 37.7, 29.9, 29.3, 26.9, 25.9, 24.4, 24.1, 19.8, 18.6, 18.5; IR (KBr) v $\max 2925$, 
2873, 1738, 1673, 1461, 1375, 1294, 1260, 1206, 1170, 1118, 1067, 974, 931, 877, 824, 806, $704 \mathrm{~cm}^{-1}$.

\section{Compound 51}

A magnetically stirred solution of acetonide 49 (501 mg, $1.44 \mathrm{mmol}$ ) in methanol/water (21 $\mathrm{mL}$ of a 4:1 v/v mixture) was treated with DOWEX-50 resin (575 mg of acidified material). The ensuing mixture was heated at $65^{\circ} \mathrm{C}$ for $56 \mathrm{~h}$ then cooled to $22^{\circ} \mathrm{C}$ and the DOWEX-50 resin removed by filtration and washed with methanol ( $3 \times 15 \mathrm{~mL})$. The combined filtrates were concentrated under reduced pressure and the aqueous residue diluted with brine (15 $\mathrm{mL}$ ) then extracted with dichloromethane $(5 \times 30 \mathrm{~mL})$. The combined organic fractions were then dried $\left(\mathrm{MgSO}_{4}\right)$, filtered and concentrated under reduced pressure. Subjection of the ensuing light-yellow oil to flash column chromatography (silica, 3:7 v/v ethyl acetate/hexane elution) afforded two fractions, $\mathrm{A}$ and $\mathrm{B}$.

Concentration of fraction A ( $R_{\mathrm{f}}=0.4$ in $3: 7 \mathrm{v} / \mathrm{v}$ ethyl acetate/hexane) afforded the starting ester 49 (75 mg, 15\% recovery) as a clear, colorless oil that was identical, in all respects, with authentic material.

Concentration of fraction B ( $R_{\mathrm{f}}=0.4$ in 4:1 v/v ethyl acetate/hexane) afforded diol 51 (345 $\mathrm{mg}, 78 \%$ at $85 \%$ conversion $)$ as a thick, white foam, $[\alpha]_{\mathrm{D}}=+2.4\left(c=1.0, \mathrm{CHCl}_{3}\right) .{ }^{1} \mathrm{H} \mathrm{NMR}$ (400 MHz, $\left.\mathrm{CDCl}_{3}\right) \delta 6.84$ (d, $J=10.2 \mathrm{~Hz}, 1 \mathrm{H}$ ), 5.89 (d, $\left.J=10.2 \mathrm{~Hz}, 1 \mathrm{H}\right), 3.96(\mathrm{~m}, 1 \mathrm{H}), 3.66$ (s, 3H), $3.43(\mathrm{~m}, 1 \mathrm{H}$ ), 3.22 (d, $J=4.3 \mathrm{~Hz}, 1 \mathrm{H}$ ), 2.58 (broad s, 1H), 2.31-2.08 (complex m, 3H), 1.94-1.85 (complex m, 3H), 1.78-1.40 (complex m, 6H), 1.18 (s, 3H); ${ }^{13} \mathrm{C}$ NMR (101 $\left.\mathrm{MHz}, \mathrm{CDCl}_{3}\right) \delta$ 203.5, 174.2, 152.8, 126.9, 72.4, 67.4, 51.8, 47.2, 38.8, 36.1, 32.6, 30.0, 29.5, 24.7, 21.7, 19.3, 18.2; IR (KBr) $v_{\max } 3297,2924,2869,1737,1668,1450,1435,1417$, 1376, 1294, 1263, 1192, 1092, 1069, 1055, 1013, 970, 944, 903, 868, 827, 795, 762, $\mathrm{cm}^{-1}$; MS (ESI, +ve) m/z 639 (100\%), $331\left[(\mathrm{M}+\mathrm{Na})^{+}, 80\right]$; HRESMS Found: $(\mathrm{M}+\mathrm{Na})^{+}, 331.1516$. $\mathrm{C}_{17} \mathrm{H}_{24} \mathrm{O}_{5}$ requires $(\mathrm{M}+\mathrm{Na})^{+}, 331.1521$.

\section{Compound 52}

A magnetically stirred mixture of $p-\mathrm{TsOH} \cdot \mathrm{H}_{2} \mathrm{O}(390 \mathrm{mg}, 2.1 \mathrm{mmol})$ and 4-acetamidoTEMPO (466 mg, $1.5 \mathrm{mmol})$ in dichloromethane $\left(25 \mathrm{~mL}\right.$ ) was maintained at $22{ }^{\circ} \mathrm{C}$ for $0.5 \mathrm{~h}$ and the resulting suspension added, in portions, to a magnetically stirred solution of 
compound 51 (308 mg, $1.0 \mathrm{mmol}$ ) in dichloromethane $(25 \mathrm{~mL})$ maintained at $0{ }^{\circ} \mathrm{C}$. The resulting mixture stirred at $0{ }^{\circ} \mathrm{C}$ for a further $2 \mathrm{~h}$ before being treated with $\mathrm{NaHCO}_{3}(25 \mathrm{~mL}$ of a saturated aqueous solution). The separated aqueous phase was extracted with dichloromethane $(4 \times 75 \mathrm{~mL})$ and the combined organic fractions washed with water $(1 \times 15$ $\mathrm{mL})$ and brine $(1 \times 15 \mathrm{~mL})$ before being dried $\left(\mathrm{Na}_{2} \mathrm{SO}_{4}\right)$, filtered and concentrated under reduced pressure. The resulting clear, light-yellow oil was subjected to flash column chromatography (silica, 3:7 v/v ethyl acetate/hexane elution) to afford, after concentration of the appropriate fractions ( $\left.R_{\mathrm{f}}=0.4\right)$, acyloin 52 (285 mg, 93\%) as a thick, light-yellow colored foam, $[\alpha]_{\mathrm{D}}==+15.9\left(c=1.0, \mathrm{CHCl}_{3}\right) .{ }^{1} \mathrm{H} \mathrm{NMR}\left(400 \mathrm{MHz}, \mathrm{CDCl}_{3}\right) \delta 6.92(\mathrm{~d}, J=10.3 \mathrm{~Hz}$, 1H), 5.98 (d, $J=10.3 \mathrm{~Hz}, 1 \mathrm{H}), 3.64$ (s, 3H), 3.38 (s, 1H), 3.17 (s, 1H), 2.57 (m, 1H), 2.242.14 (complex m, 2H), 2.10-1.59 (complex m, 8H), 1.42 (m, 1H), 1.25 (s, 3H); ${ }^{13} \mathrm{C}$ NMR $\left(101 \mathrm{MHz}, \mathrm{CDCl}_{3}\right) \delta 216.2,202.6,173.8,149.6,127.7,78.8,51.8,47.5,41.9(3), 41.9(0)$, 38.2, 30.3, 29.4, 25.8, 23.7, 21.1, 20.4; IR (KBr) vmax 3450, 2950, 2875, 1731, 1671, 1469, 1439, 1387, 1364, 1295, 1232, 1198, 1175, 1103, 1061, 993, 929, 851, 828, 752, 707, 577 $\mathrm{cm}^{-1}$; MS (ESI, +ve) m/z 361 (100\%), 329 [(M+Na) , 61], 307 (60), 275 (70); HRESMS Found: $(\mathrm{M}+\mathrm{Na})^{+}$, 329.1363. $\mathrm{C}_{17} \mathrm{H}_{22} \mathrm{O}_{5}$ requires $(\mathrm{M}+\mathrm{Na})^{+}, 329.1365$.

\section{Compound 53}

A magnetically stirred solution of acyloin 52 (125 mg, $0.41 \mathrm{mmol})$, triethylamine $(1.7 \mathrm{~mL})$ and DMAP (124 mg, $1.02 \mathrm{mmol})$ in dichloromethane $(7 \mathrm{~mL})$ was cooled to $0{ }^{\circ} \mathrm{C}$ then treated with benzoyl chloride $(119 \mu \mathrm{L}, 1.02 \mathrm{mmol})$. The resulting mixture was allowed to warm to $22{ }^{\circ} \mathrm{C}$, stirred vigorously at this temperature for $16 \mathrm{~h}$ then treated with $\mathrm{HCl}(15 \mathrm{~mL}$ of a $1 \mathrm{M}$ aqueous solution) and extracted with dichloromethane (5 x $15 \mathrm{~mL})$. The combined organic phases were washed with brine ( 1 x $15 \mathrm{~mL})$ before being dried $\left(\mathrm{Na}_{2} \mathrm{SO}_{4}\right)$, filtered and concentrated under reduced pressure. The resulting light-yellow oil was subjected to flash column chromatography (silica, 1:9 v/v ethyl acetate/hexane elution) and concentration of the appropriate fractions $\left(R_{\mathrm{f}}=0.6\right.$ in 3:7 v/v ethyl acetate/hexane) gave compound 53 (147 mg, $89 \%)$ as a clear, colorless foam, $[\alpha]_{\mathrm{D}}=+91.5\left(c=1.0, \mathrm{CHCl}_{3}\right) .{ }^{1} \mathrm{H} \mathrm{NMR}\left(400 \mathrm{MHz}, \mathrm{CDCl}_{3}\right)$

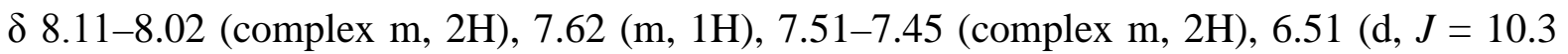
Hz, 1H), 5.96 (d, $J=10.3 \mathrm{~Hz}, 1 \mathrm{H}), 5.04$ (s, 1H), 3.66 (s, 3H), 2.67 (s, 1H), 2.33-1.98 (complex m, 9H), $1.84(\mathrm{~m}, 1 \mathrm{H}), 1.96(\mathrm{~m}, 1 \mathrm{H}), 1.28(\mathrm{~s}, 3 \mathrm{H}) ;{ }^{13} \mathrm{C}$ NMR $\left(101 \mathrm{MHz}, \mathrm{CDCl}_{3}\right) \delta$ 
209.2, 202.0, 173.7, 165.6, 147.4, 133.9, 130.1, 129.0, 128.8, 128.1, 77.1, 51.9, 47.5, 42.5, 41.3, 37.7, 30.1, 29.3, 24.8, 23.9, 21.3, 21.2; IR (KBr) $v_{\max } 2948,2874,1729,1674,1601$, 1468, 1451, 1390, 1314, 1253, 1197, 1176, 1108, 1069, 1026, 988, 803, $710 \mathrm{~cm}^{-1}$; MS (ESI, +ve) m/z 465 (63\%), $433\left[(\mathrm{M}+\mathrm{Na})^{+}, 100\right], 411$ (35); HRESMS Found: $(\mathrm{M}+\mathrm{Na})^{+}, 433.1629$. $\mathrm{C}_{24} \mathrm{H}_{26} \mathrm{O}_{6}$ requires $(\mathrm{M}+\mathrm{Na})^{+}$, 433.1627 .

\section{Compound 54}

A vigorously stirred solution of methyl triphenylphosphonium bromide ( $89 \mathrm{mg}, 0.25 \mathrm{mmol}$ ) in freshly distilled THF (5 mL) maintained at $0{ }^{\circ} \mathrm{C}$ was treated, dropwise via syringe, with KHMDS ( $650 \mu \mathrm{L}$ of a $0.5 \mathrm{M}$ solution in toluene). The resulting yellow solution was stirred for $0.5 \mathrm{~h}$, warmed to $22{ }^{\circ} \mathrm{C}$ over $0.5 \mathrm{~h}$ then cooled to $-78^{\circ} \mathrm{C}$. A solution of keto-ester 53 (55 $\mathrm{mg}, 0.13 \mathrm{mmol})$ in THF $(2.5 \mathrm{~mL})$ was then added, dropwise, to the reaction mixture after which it was stirred at $-78{ }^{\circ} \mathrm{C}$ for a further $1.5 \mathrm{~h}$ before being quenched with $\mathrm{NH}_{4} \mathrm{Cl}(10 \mathrm{~mL}$ of saturated aqueous solution) then, upon warming, extracted with diethyl ether (5 x $5 \mathrm{~mL}$ ). The combined organic phases were washed with brine $(1 \times 5 \mathrm{~mL})$ then dried $\left(\mathrm{Na}_{2} \mathrm{SO}_{4}\right)$, filtered and concentrated under a stream of nitrogen. Subjection of the ensuing light-yellow oil to flash column chromatography (silica, 1:4 v/v ethyl acetate/hexane elution) afforded, after concentration of the appropriate fractions $\left(R_{\mathrm{f}}=0.6\right)$, compound $54(37.8 \mathrm{mg}, 71 \%)$ as a clear, colorless foam, $[\alpha]_{\mathrm{D}}=+21.3\left(c=1.0, \mathrm{CHCl}_{3}\right) .{ }^{1} \mathrm{H}$ NMR $\left(400 \mathrm{MHz}, \mathrm{CDCl}_{3}\right) \delta 8.07(\mathrm{~m}$, 2H), 7.60 (m, 1H), 7.48 (t, $J=7.6 \mathrm{~Hz}, 2 \mathrm{H}), 6.55$ (d, $J=10.3 \mathrm{~Hz}, 1 \mathrm{H}), 5.90$ (d, $J=10.3 \mathrm{~Hz}$, 1H), 5.38 (s, 1H), 5.21 (s, 1H), 5.12 (s, 1H), 3.66 (s, 3H), 2.59 (s, 1H), 2.32-2.05 (complex m, 4H), 2.01-1.25 (complex m, 7H), 1.23 (s, 3H); ${ }^{13} \mathrm{C}$ NMR (101 MHz, $\mathrm{CDCl}_{3}$ ) $\delta 203.0$, 174.1, 166.5, 149.8, 148.5, 133.4, 130.3, 129.9, 128.7, 127.6, 114.6, 76.0, 51.8, 47.3, 39.1, 37.1, 35.5, 30.0, 29.4, 27.5, 25.9, 22.0, 21.0; IR (KBr) $v_{\max }$ 2956, 2929, 2854, 1740, 1720, 1677, 1464, 1452, 1442, 1377, 1261, 1179, 1110, 1072, 1027, 975, 804, $711 \mathrm{~cm}^{-1}$; MS (ESI, + ve) $m / z 431$ [(M+Na) $\left.{ }^{+}, 100 \%\right], 409$ (42); HRESMS Found: $(\mathrm{M}+\mathrm{Na})^{+}$, 431.1844. $\mathrm{C}_{25} \mathrm{H}_{28} \mathrm{O}_{5}$ requires $(\mathrm{M}+\mathrm{Na})^{+}, 431.1834$.

\section{Compound 55}

A magnetically stirred solution of ester 49 (87 mg, $0.25 \mathrm{mmol})$ in THF (10 mL) maintained at $50{ }^{\circ} \mathrm{C}$ was treated with $\mathrm{LiOH}(10 \mathrm{~mL}$ of a $1 \mathrm{M}$ aqueous solution) and the ensuing mixture 
stirred at this temperature for $5 \mathrm{~h}$. The cooled reaction mixture was treated with water (15 $\mathrm{mL})$ and brine $(10 \mathrm{~mL})$ before being washed with diethyl ether $(1 \times 20 \mathrm{~mL})$. The separated aqueous layer was then acidified with $\mathrm{HCl}(15 \mathrm{~mL}$ of a $1 \mathrm{M}$ aqueous solution) and extracted with diethyl ether $(10 \times 5 \mathrm{~mL})$. The combined organic extracts were dried $\left(\mathrm{Na}_{2} \mathrm{SO}_{4}\right)$, filtered then concentrated under reduced pressure and the residue thus obtained subjected to flash column chromatography (silica, 55:45 v/v ethyl acetate/hexane elution). Concentration of the appropriate fractions ( $R_{\mathrm{f}}=0.2 \mathrm{in} 1: 1 \mathrm{v} / \mathrm{v}$ ethyl acetate/hexane) gave acid 55 (81 $\left.\mathrm{mg}, 97 \%\right)$ as a clear, colorless and viscous foam, $[\alpha]_{\mathrm{D}}=+6.1\left(c=1.0, \mathrm{CHCl}_{3}\right) .{ }^{1} \mathrm{H} \mathrm{NMR}(400 \mathrm{MHz}$, $\left.\mathrm{CDCl}_{3}\right) \delta 6.74(\mathrm{~d}, J=10.1 \mathrm{~Hz}, 1 \mathrm{H}), 5.89$ (d, $\left.J=10.1 \mathrm{~Hz}, 1 \mathrm{H}\right), 4.19$ (m, 1H), 3.69 (d, 1H), 2.34-2.12 (complex m, 3H), 2.03 (m, 1H), 1.96-1.81 (complex m, 2H), 1.77-1.55 (complex m, 5H), 1.52 (s, 3H), 1.35 (s, 3H), 1.33-1.23 (complex m, 2H), 1.19 (s, 3H); ${ }^{13} \mathrm{C}$ NMR (101 $\left.\mathrm{MHz}, \mathrm{CDCl}_{3}\right) \delta 203.5,179.1,152.5,126.9,109.4,79.4,75.4,47.3,37.6,36.7,30.2,29.6$, 29.5, 25.9, 24.4, 23.7, 21.2, 19.4, 18.5; IR (KBr) v $v_{\max }$ 2978, 2934, 1708, 1673, 1469, 1454, 1440, 1381, 1311, 1280, 1260, 1208, 1164, 1131, 1116, 1087, 1066, 1033, 970, 931, 874,

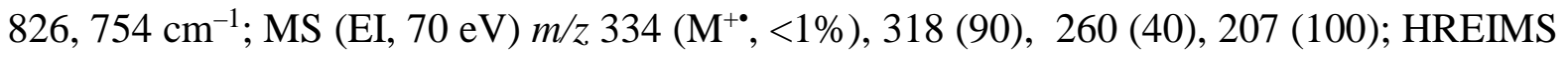
Found: $\mathrm{M}^{+\bullet}$, 334.1767. $\mathrm{C}_{19} \mathrm{H}_{26} \mathrm{O}_{5}$ requires $\mathrm{M}^{+\bullet}$, 334.1780.

\section{Compound 56}

A magnetically stirred solution of 2-(trimethylsilyl)ethyl 2,4-dihydroxy-3-nitrobenzoate ${ }^{19}$ (1.00 g, $3.34 \mathrm{mmol})$ in ethyl acetate/methanol (65 $\mathrm{mL}$ of a 5:1 v/v mixture) was treated with acetic acid $(190 \mu \mathrm{L})$ and 10\% palladium on carbon $(185 \mathrm{mg})$. The resulting suspension was stirred at $22{ }^{\circ} \mathrm{C}$ under a hydrogen atmosphere for $16 \mathrm{~h}$ after which time it was filtered through a pad of Celite ${ }^{\mathrm{TM}}$ that was washed with ethyl acetate $(50 \mathrm{~mL})$. The combined filtrates were concentrated under reduced pressure to afford a dark solid, recrystallization (hexane) of which afforded aniline $\mathbf{5 6}^{19}$ (710 mg, 79\%) as grey solid, m.p. $=107{ }^{\circ} \mathrm{C} .{ }^{1} \mathrm{H}$ NMR $(400 \mathrm{MHz}$, $\left.\mathrm{CDCl}_{3}\right) \delta 11.19(\mathrm{~s}, 1 \mathrm{H}), 7.33(\mathrm{~d}, J=8.3 \mathrm{~Hz}, 1 \mathrm{H}), 6.35$ (d, $\left.J=8.3 \mathrm{~Hz}, 1 \mathrm{H}\right), 4.51-4.37$ (complex m, 3H), $1.12(\mathrm{~m}, 2 \mathrm{H}), 0.11(\mathrm{~s}, 9 \mathrm{H})$ (resonances due to $\mathrm{OH}$ group protons not observed); ${ }^{13} \mathrm{C}$ NMR (101 $\left.\mathrm{MHz}, \mathrm{CDCl}_{3}\right) \delta 170.8,153.0,151.3,122.0,121.1,106.9,106.2$, 63.6, 17.5, -1.30; IR (KBr) $v_{\max } 3381,3310,3110,2954,2900,1661,1625,1506,1468$, 1387, 1288, 1250, 1217, 1175, 1143, 1062, 1044, 941, 860, 837, 778, $694 \mathrm{~cm}^{-1}$; MS (EI, 70 
eV) m/z 269 (M+*, 5\%), 267 (8), 241 (21), 226 (19), 152 (31), 151 (100), 73 (41); HREIMS Found: $\mathrm{M}^{+\bullet}$, 269.1084. $\mathrm{C}_{12} \mathrm{H}_{19} \mathrm{NO}_{4}$ requires $\mathrm{M}^{+\bullet}$, 269.1083.

\section{Compound 57}

A magnetically stirred solution of compound 55 (70 mg, $0.21 \mathrm{mmol})$ and aniline 56 (117 mg, $0.69 \mathrm{mmol})$ in DMF $(750 \mu \mathrm{L})$ maintained at $22{ }^{\circ} \mathrm{C}$ under an argon atmosphere was treated with dry triethylamine $(120 \mu \mathrm{L}, 0.88 \mathrm{mmol})$ and HATU $(263 \mathrm{mg}, 0.69 \mathrm{mmol})$. After $16 \mathrm{~h}$ the reaction mixture was quenched with brine $(1.9 \mathrm{~mL})$ then extracted with chloroform $(3 \times 10$ $\mathrm{mL})$. The combined organic phases were dried $\left(\mathrm{Na}_{2} \mathrm{SO}_{4}\right)$, filtered and concentrated under reduced pressure. The ensuing dark residue was subjected to flash column chromatography (silica, 1:10 v/v ethyl acetate/hexane elution) and concentration of the relevant fractions $\left(R_{\mathrm{f}}=\right.$ 0.6 in 3:7 v/v ethyl acetate/hexane) afforded amide 57 (39.2 mg, 32\%) as light-yellow and viscous film, $[\alpha]_{\mathrm{D}}=-5.9\left(c=0.1, \mathrm{CHCl}_{3}\right) .{ }^{1} \mathrm{H} \mathrm{NMR}\left(400 \mathrm{MHz}, \mathrm{CDCl}_{3}\right) \delta 11.84(\mathrm{~s}, 1 \mathrm{H})$, 11.01 (broadened s, 1H), 8.12 (s, 1H), 7.56 (d, $J=9.0 \mathrm{~Hz}, 1 \mathrm{H}$ ), 6.75 (d, $J=10.2 \mathrm{~Hz}, 1 \mathrm{H}$ ), 6.50 (d, $J=9.0 \mathrm{~Hz}, 1 \mathrm{H}$ ), 5.94 (d, $J=10.2 \mathrm{~Hz}, 1 \mathrm{H}$ ), 4.42 (m, 2H), 4.19 (m, 1H), 3.70 (dd, $J=$ 8.0 and $1.6 \mathrm{~Hz}, 1 \mathrm{H}), 2.41$ (m, 2H), 2.22 (m, 1H), 2.09-1.27 (complex m, 9H), 1.55 (s, 3H), 1.35 (s, 3H), 1.24 (s, 3H), 1.16-1.09 (complex m, 2H), 0.08 (s, 9H); ${ }^{13} \mathrm{C}$ NMR (101 MHz, $\left.\mathrm{CDCl}_{3}\right) \delta 203.9,174.0,170.6,154.8,154.1,152.9,127.6,126.9,114.5,111.3,109.5,104.6$, 79.4, 75.4, 63.9, 47.8, 37.7, 36.9, 32.7, 31.6, 29.6, 25.9, 24.4, 23.8, 21.1, 19.4, 18.5, 17.5, 1.3; IR (KBr) v $v_{\max } 3319,2924,2807,1654,1597,1535,1467,1385,1331,1292,1259,1208$, 1147, 1115, 1087, 1064, 969, 932, 859, 837, $789 \mathrm{~cm}^{-1}$; MS (EI, $\left.70 \mathrm{eV}\right) \mathrm{m} / \mathrm{z} 585\left(\mathrm{M}^{+\bullet}\right.$, 5\%), 570 (5), 317 (100), 259 (38), 241 (42), 204 (31), 151 (42), 73 (48); HREIMS Found: $M^{+\bullet}$, 585.2755. $\mathrm{C}_{31} \mathrm{H}_{43} \mathrm{NO}_{8} \mathrm{Si}$ requires $\mathrm{M}^{+\bullet}$ 585.2758.

\section{Compound 58}

A magnetically stirred solution of compound 57 (29 mg, $0.05 \mathrm{mmol}$ ) in DMF (500 $\mu \mathrm{L}$ ) maintained under a nitrogen atmosphere at $22{ }^{\circ} \mathrm{C}$ was treated with TASF (28 mg, 0.10 mmol). The ensuing mixture was heated at $40{ }^{\circ} \mathrm{C}$ for $1 \mathrm{~h}$ then cooled and quenched with brine $(4 \mathrm{~mL})$. The separated aqueous phase was extracted with chloroform $(5 \times 5 \mathrm{~mL})$ and the combined organic fractions were then dried $\left(\mathrm{Na}_{2} \mathrm{SO}_{4}\right)$, filtered and concentrated under reduced pressure. The residue thus obtained was subjected to flash column chromatography 
(silica, 8:12:0.1:0.1:0.1 v/v ethyl acetate/hexane/acetic acid/methanol/water elution) and concentration of the relevant fractions $\left(R_{\mathrm{f}}=0.3\right.$ in 80:20:0.5:1.0:0.5 v/v ethyl acetate/ hexane/acetic acid/methanol/water) afforded compound 58 (5 mg, 21\%) as a light-brown foam, $[\alpha]_{\mathrm{D}}=-29.0\left(c=0.1, \mathrm{CHCl}_{3}\right) .{ }^{1} \mathrm{H}$ NMR $\left(400 \mathrm{MHz}, \mathrm{CDCl}_{3}\right) \delta 11.86(\mathrm{~s}, 1 \mathrm{H}), 11.12(\mathrm{~s}$, 1H), 8.20 (s, 1H), 7.63 (dd, $J=8.9$ and $0.8 \mathrm{~Hz}, 1 \mathrm{H}$ ), 6.82 (d, $J=10.1 \mathrm{~Hz}, 1 \mathrm{H}$ ), 6.52 (dd, $J=$ 8.9 and $0.7 \mathrm{~Hz}, 1 \mathrm{H}$ ), 5.96 (dd, $J=10.1$ and $0.7 \mathrm{~Hz}, 1 \mathrm{H}), 4.21$ (m, 1H), 3.71 (m, 1H), 2.512.35 (complex m, 2H), 2.21 (m, 1H), 2.12-1.29 (complex m, 6H), 1.55 (s, 3H), 1.36 (s, 3H), 1.27 (m, 3H), 1.26 (s, 3H) (resonance due to amide or $\mathrm{OH}$ group proton not observed); ${ }^{13} \mathrm{C}$ NMR (101 MHz, $\left.\mathrm{CDCl}_{3}\right) \delta$ 205.2, 174.0, 172.8, 155.5, 154.6, 154.3, 128.5, 126.7, 114.5, 111.4, 109.5, 103.6, 79.3, 75.4, 47.8, 37.8, 36.7, 32.5, 31.8, 29.5, 25.9, 24.4, 23.7, 21.4, 19.5, 18.5; IR (KBr) $v_{\max } 2928,2859,1654,1537,1451,1379,1259,1064,875,795 \mathrm{~cm}^{-1}$; MS

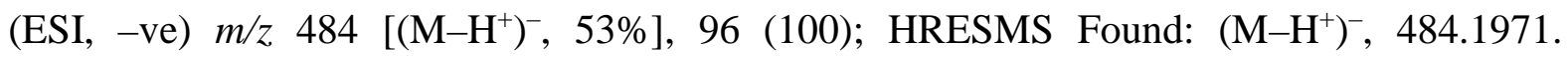
$\mathrm{C}_{26} \mathrm{H}_{31} \mathrm{NO}_{8}$ requires $\left(\mathrm{M}-\mathrm{H}^{+}\right)^{-}$, 484.1971.

\section{Compound 59}

A magnetically stirred solution of ester 50 (53 mg, $0.15 \mathrm{mmol})$ in THF ( $5 \mathrm{~mL}$ ) maintained at $50{ }^{\circ} \mathrm{C}$ was treated with $\mathrm{LiOH}$ ( $5 \mathrm{~mL}$ of a $1 \mathrm{M}$ aqueous solution) and the ensuing mixture stirred at this temperature for $5 \mathrm{~h}$. After this time the reaction mixture was cooled then treated with water $(7 \mathrm{~mL})$ and brine $(5 \mathrm{~mL})$ before being washed with dichloromethane $(2 \times 10 \mathrm{~mL})$. The separated aqueous layer was acidified to $\mathrm{pH} 2$ (with $1 \mathrm{M}$ aqueous $\mathrm{HCl}$ ) and extracted with dichloromethane $(7 \times 4 \mathrm{~mL})$. The combined organic extracts were then dried $\left(\mathrm{MgSO}_{4}\right)$, filtered and concentrated under reduced pressure. The residue thus obtained was subjected to flash column chromatography (silica, 55:45 v/v ethyl acetate/hexane elution) and concentration of the appropriate fractions $\left(R_{\mathrm{f}}=0.2\right.$ in $1: 1 \mathrm{v} / \mathrm{v}$ ethyl acetate/hexane) gave acid 59 (48 mg, 95\%) as a clear, colorless foam, $[\alpha]_{\mathrm{D}}=+61.3\left(c=1.0, \mathrm{CHCl}_{3}\right) .{ }^{1} \mathrm{H}$ NMR $(400$ $\left.\mathrm{MHz}, \mathrm{CDCl}_{3}\right) \delta 6.72(\mathrm{~d}, J=10.2 \mathrm{~Hz}, 1 \mathrm{H}), 5.88(\mathrm{~d}, J=10.2 \mathrm{~Hz}, 1 \mathrm{H}), 4.19(\mathrm{~m}, 1 \mathrm{H}), 3.65$ (dd, $J=8.1$ and $1.6 \mathrm{~Hz}, 1 \mathrm{H}), 2.35$ (m, 1H), 2.18 (m, 1H), 2.07-1.35 (complex m, 11H), 1.43 (s, 3H), 1.34 (s, 3H), 1.25 (s, 3H); ${ }^{13} \mathrm{C}$ NMR (101 MHz, $\left.\mathrm{CDCl}_{3}\right) \delta$ 203.2, 178.5, 152.3, 126.3, 109.5, 79.7, 75.6, 47.2, 42.7, 37.7, 30.5, 29.2, 26.7, 25.9, 24.4, 24.1, 19.9, 18.6, 18.5; IR (KBr) $v_{\max } 2977,2934,2872,1728,1674,1458,1368,1296,1260,1153,1119,1066,975$, 
876, 848, $755 \mathrm{~cm}^{-1}$; MS (EI, $70 \mathrm{eV)} \mathrm{m/z} 334\left(\mathrm{M}^{+\bullet}, 11 \%\right), 319$ (30), 233 (75), 190 (70), 146 (100), 121 (80); HREIMS Found: $\mathrm{M}^{+\bullet}$, 334.1799. $\mathrm{C}_{19} \mathrm{H}_{26} \mathrm{O}_{5}$ requires $\mathrm{M}^{+\bullet}$, 334.1780.

\section{Compound 61}

Method i: A magnetically stirred solution of compound 59 (50 mg, $0.15 \mathrm{mmol}$ ) in acetonitrile $(1.5 \mathrm{~mL})$ maintained at $22{ }^{\circ} \mathrm{C}$ was treated with dry triethylamine $(62 \mu \mathrm{L}, 0.45 \mathrm{mmol})$, DMAP (37 $\mathrm{mg}, 0.30 \mathrm{mmol})$ and $\mathrm{DCC}(230 \mu \mathrm{L}$ of a $1.0 \mathrm{M}$ solution in freshly distilled dichloromethane, $0.23 \mathrm{mmol}$ ). After $5 \mathrm{~h}$ a solution of 3-amino-2,4-dihydroxy benzoic acid (60) (49.5 mg , $0.30 \mathrm{mmol})$ in DMF (350 $\mu \mathrm{L}$ ) was added to the reaction mixture and stirring continued for another $36 \mathrm{~h}$. The resulting mixture was concentrated under reduced pressure and the residue thus obtained subjected to flash column chromatography (silica, 80:20:1:0.5:0.5 v/v ethyl acetate/hexane/methanol/acetic acid/water elution) and thus affording, after concentration of the relevant fractions $\left(R_{\mathrm{f}}=0.3\right.$ in 80:20:0.5:1.0:0.5 v/v ethyl acetate/hexane/methanol/ acetic acid/water), compound 61 (15 mg, 21\%) as a light-orange foam, $[\alpha]_{\mathrm{D}}=-9.2\left(c=0.1, \mathrm{CHCl}_{3}\right) .{ }^{1} \mathrm{H}$ NMR $\left(400 \mathrm{MHz} \mathrm{CDCl}_{3}\right) \delta 11.90(\mathrm{~s}, 1 \mathrm{H}), 11.31(\mathrm{~s}$, 1H), 8.09 (s, 1H), 7.63 (d, $J=8.9 \mathrm{~Hz}, 1 \mathrm{H}), 6.85$ (d, $J=10.1 \mathrm{~Hz}, 1 \mathrm{H}), 6.51$ (d, $J=8.9 \mathrm{~Hz}$, 1H), 5.97 (d, $J=10.1 \mathrm{~Hz}, 1 \mathrm{H}), 4.22$ (m, 1H), 3.68 (d, $J=7.9 \mathrm{~Hz}, 1 \mathrm{H}), 2.52-1.26$ (complex $\mathrm{m}, 12 \mathrm{H}), 1.36(\mathrm{~s}, 6 \mathrm{H}), 1.15(\mathrm{~s}, 3 \mathrm{H})$ (resonance due to amide or $\mathrm{OH}$ group proton not observed); ${ }^{13} \mathrm{C}$ NMR (101 MHz, $\left.\mathrm{CDCl}_{3}\right) \delta$ 205.5, 173.4, 172.4, 155.0, 154.6, 154.2, 128.2, 125.7, 114.2, 111.1, 109.4, 103.4, 79.3, 75.4, 47.5, 42.5, 37.9, 31.8, 29.7, 27.6, 25.8, 24.3, 23.9, 19.7, 18.5, 18.2; IR (KBr) $v_{\max } 3307,2924,2853,1658,1647,1535,1456,1379,1260$, 1208, 1154, 1119, 1065, 910, 874, 799, 733, $608 \mathrm{~cm}^{-1}$; MS (ESI, -ve) m/z $484\left[\left(\mathrm{M}-\mathrm{H}^{+}\right)^{-}\right.$, 18\%], 134 (100), 105 (38); HREIMS Found: $\left(\mathrm{M}-\mathrm{H}^{+}\right)^{-}$, 484.1970. $\mathrm{C}_{26} \mathrm{H}_{31} \mathrm{NO}_{8}$ requires (M$\left.\mathrm{H}^{+}\right)^{-} 484.1971$.

Method ii: A magnetically stirred solution of compound 59 (21 mg, $0.063 \mathrm{mmol})$ in DMF $(1.0 \mathrm{~mL})$ maintained at $22{ }^{\circ} \mathrm{C}$ was treated with DMAP (5 mg, $\left.0.164 \mathrm{mmol}\right)$ and EDC (15.4 $\mathrm{mg}, 0.081 \mathrm{mmol})$. After $5 \mathrm{~h}$ a solution of 3-amino-2,4-dihydroxy benzoic acid (60) (21.9 mg, $0.13 \mathrm{mmol})$ in DMF (250 $\mu \mathrm{L})$ was added to the reaction mixture and stirring continued for 36 $\mathrm{h}$ at which point water $(7 \mathrm{~mL})$ was added and $\mathrm{pH}$ of the ensuing mixture was adjusted to 4 using $\mathrm{HCl}$ (1 $\mathrm{M}$ aqueous solution) then extracted with dichloromethane (5 x $10 \mathrm{~mL})$. The combined organic phases were dried $\left(\mathrm{MgSO}_{4}\right)$, filtered and concentrated under reduced 
pressure. The ensuing light-yellow oil was subjected to flash column chromatography (silica, 75:25:1:0.5:0.5 v/v ethyl acetate/hexane/methanol/acetic acid/water elution) and thus affording, after concentration of the relevant fractions $\left(R_{\mathrm{f}}=0.3\right.$ in 80:20:0.5:1.0:0.5 v/v ethyl acetate/hexane/methanol/acetic acid/water), compound $\mathbf{6 1}(8.2 \mathrm{mg}, 27 \%)$ as a thick foam. This material was identical, in all respects, with that obtained by Method $i$ described immediately above.

\section{Compound 63}

A magnetically stirred solution of compound $62^{8}$ (63 mg, $\left.0.19 \mathrm{mmol}\right)$ and aniline 56 (101 $\mathrm{mg}, 0.60 \mathrm{mmol})$ in DMF $(0.67 \mathrm{~mL})$ maintained at $22{ }^{\circ} \mathrm{C}$ under a nitrogen atmosphere was treated with triethylamine $(110 \mu \mathrm{L}, 0.81 \mathrm{mmol})$ and HATU $(228 \mathrm{mg}, 0.60 \mathrm{mmol})$. After $16 \mathrm{~h}$ the reaction mixture was quenched with brine $(1 \mathrm{~mL})$ and extracted with chloroform $(3 \times 5$ $\mathrm{mL})$. The combined organic phases were dried $\left(\mathrm{Na}_{2} \mathrm{SO}_{4}\right)$, filtered and concentrated under reduced pressure. The dark residue thus obtained was subjected to flash column chromatography (silica, 1:10 v/v ethyl acetate/hexane elution) and concentration of the relevant fractions ( $R_{\mathrm{f}}=0.6$ in 3:7 v/v ethyl acetate/hexane) afforded amide 63 (16 mg, 14\%) as white film. This material was immediately subjected to treatment with TASF as described below.

\section{Compound 64}

A magnetically stirred solution of TMSE amide 63 (12 mg, $0.02 \mathrm{mmol})$ in DMF (0.18 mL) maintained under a nitrogen atmosphere at $22{ }^{\circ} \mathrm{C}$ was treated with TASF (11.2 mg, 0.04 $\mathrm{mmol}$ ). The ensuing mixture was heated at $40{ }^{\circ} \mathrm{C}$ for $1 \mathrm{~h}$ then cooled and quenched with brine (2 $\mathrm{mL})$. The separated aqueous phase was extracted with chloroform $(5 \times 2 \mathrm{~mL})$ and the combined organic fractions were then dried $\left(\mathrm{Na}_{2} \mathrm{SO}_{4}\right)$, filtered and concentrated under reduced pressure. The residue thus obtained was subjected to flash column chromatography (silica, 8:12:0.1:0.1:0.1 $\mathrm{v} / \mathrm{v}$ ethyl acetate/hexane/acetic acid/methanol/water elution) and concentration of the relevant fractions $\left(R_{\mathrm{f}}=0.3\right.$ in 80:20:0.5:1.0:0.5 v/v ethyl acetate/hexane/acetic acid/methanol/water) afforded compound $64(1.5 \mathrm{mg}, 15 \%)$ as a white film, $[\alpha]_{\mathrm{D}}=-24.0\left(c=0.1, \mathrm{CHCl}_{3}\right) .{ }^{1} \mathrm{H} \mathrm{NMR}$ $\left(400 \mathrm{MHz}, \mathrm{CDCl}_{3}\right) \delta 11.52(\mathrm{~s}, 1 \mathrm{H}), 11.24(\mathrm{~s}, 1 \mathrm{H}), 8.32$ (s, 1H), 7.63 (d, J = 9.2 Hz, 1H), 6.54 (d, $J=9.2,1 \mathrm{H}), 4.20(\mathrm{~m}, 1 \mathrm{H}), 3.64(\mathrm{~m}, 1 \mathrm{H}), 2.68(\mathrm{~m}, 1 \mathrm{H}), 2.48(\mathrm{~m}, 2 \mathrm{H}), 2.27(\mathrm{~m}, 1 \mathrm{H}), 2.04-$ 
1.73 (complex m, 6H), 1.63-1.51 (complex m, 3H), 1.52 (s, 3H), 1.36 (s, 3H), 1.31 (s, 3H) (resonances due to amide and $\mathrm{OH}$ group protons not observed); ${ }^{13} \mathrm{C}$ NMR (200 MHz, $\mathrm{CDCl}_{3}$ )

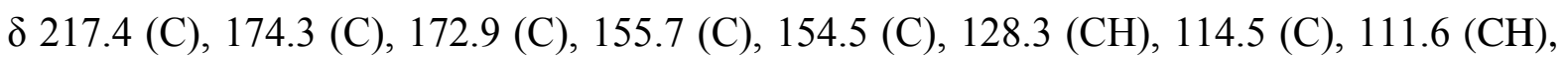
$108.8(\mathrm{C}), 103.1(\mathrm{C}), 82.2(\mathrm{CH}), 75.9(\mathrm{CH}), 51.0(\mathrm{C}), 41.0(\mathrm{CH}), 34.7(\mathrm{C}), 34.0\left(\mathrm{CH}_{2}\right), 33.5$ $\left(\mathrm{CH}_{2}\right), 32.8\left(\mathrm{CH}_{2}\right), 32.7\left(\mathrm{CH}_{2}\right), 29.0(\mathrm{CH}), 25.8\left(\mathrm{CH}_{3}\right), 24.2\left(\mathrm{CH}_{3}\right), 20.4\left(\mathrm{CH}_{3}\right), 19.7\left(\mathrm{CH}_{2}\right)$, $19.1\left(\mathrm{CH}_{2}\right)$ (one resonance obscured or overlapping); IR (KBr) $v_{\max } 3292$, 3072, 2933, 2619, 1696, 1654, 1597, 1534, 1453, 1380, 1260, 1241, 1209, 1153, 1062, 1038, 910, 875, 794, 732

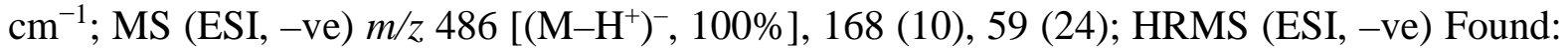
$\left(\mathrm{M}-\mathrm{H}^{+}\right)^{-}$, 486.2129. $\mathrm{C}_{26} \mathrm{H} 33 \mathrm{NO}$ 8 requires $\left(\mathrm{M}-\mathrm{H}^{+}\right)^{-} 486.2128$. 


\section{X-ray Crystallographic Studies}

\section{Crystallographic Data}

Crystallographic Data for the Admixture of Compounds 15 and 32

$\mathrm{C}_{16} \mathrm{H}_{22} \mathrm{O}_{3}, M=262.34, T=150 \mathrm{~K}$, monoclinic, space group $P 2_{1}, Z=4, a=6.34903(17), b=$ 9.1348(2), $c=23.8101(7) \AA \AA \beta=95.882(3) ; V=1373.65(6) \AA^{3}, D_{x}=1.269 \mathrm{~g} \mathrm{~cm}^{-3}, 5468$ unique data $\left(2 \theta_{\max }=148.2^{\circ}\right), R=0.039$ [for 4880 reflections with $I>2.0 \sigma(I)$ ]; $R w=0.095$ (all data), $S=1.01$.

Crystallographic Data for Compound 28

$\mathrm{C}_{17} \mathrm{H}_{24} \mathrm{O}_{3}, M=276.38, T=150 \mathrm{~K}$, orthorhombic, space group $P 2{ }_{1}{ }_{2}{ }_{2}{ }_{1}, Z=4, a=6.4901(1)$, $b=11.7812(1), c=18.7583(2) \AA ; V=1434.28(3) \AA^{3}, D_{x}=1.280 \mathrm{~g} \mathrm{~cm}^{-3}, 2831$ unique data $\left(2 \theta_{\max }=144.6^{\circ}\right), R=0.028$ [for 2753 reflections with $I>2.0 \sigma(I)$ ]; $R w=0.069$ (all data), $S=$ 1.00 .

\section{Crystallographic Data for Compound 34}

$\mathrm{C}_{15} \mathrm{H}_{18} \mathrm{O}_{3}, M=246.31, T=150 \mathrm{~K}$, monoclinic, space group $P 2_{1}, Z=6, a=12.1619(3), b=$ 8.3569(2), $c=18.7928(4) \AA ; \beta=97.273(2)^{\circ} ; V=1894.65(8) \AA^{3}, D_{x}=1.295 \mathrm{~g} \mathrm{~cm}^{-3}, 6248$ unique data $\left(2 \theta_{\max }=144.8^{\circ}\right), R=0.033$ [for 5917 reflections with $I>2.0 \sigma(I)$ ]; $R w=0.081$ (all data), $S=1.00$.

Crystallographic Data for Compound 35

$\mathrm{C}_{15} \mathrm{H}_{18} \mathrm{BrO}_{3}, M=246.31, T=150 \mathrm{~K}$, monoclinic, space group $P 2_{1}, Z=4, a=6.2911(4), b=$ 35.4329(15), $c=6.4453(4) \AA ; \beta=118.271(8)^{\circ} ; V=1265.36(16) \AA^{3}, D_{x}=1.293 \mathrm{~g} \mathrm{~cm}^{-3}$, 2533 unique data $\left(2 \theta_{\max }=144.6^{\circ}\right), R=0.064$ [for 2454 reflections with $I>2.0 \sigma(I)$ ]; $R w=$ 0.166 (all data), $S=1.01$.

Crystallographic Data for Compound 37

$\mathrm{C}_{16} \mathrm{H}_{22} \mathrm{O}_{3}, M=262.35, T=150 \mathrm{~K}$, orthorhombic, space group $P 2{ }_{1}{ }_{2}{ }_{2}{ }_{1}, Z=4, a=8.0668(2)$, $b=9.8097(3), c=18.1236(6) \AA ; V=1434.17(7) \AA^{3}, D_{x}=1.215 \mathrm{~g} \mathrm{~cm}^{-3}, 2830$ unique data $\left(2 \theta_{\max }=145.4^{\circ}\right), R=0.032$ [for 2698 reflections with $I>2.0 \sigma(I)$ ]; $R w=0.088$ (all data), $S=$ 1.00 . 


\section{Structure Determinations}

Images were measured on a diffractometer ( $\mathrm{Cu} \mathrm{K \alpha}$, mirror monochromator, $\lambda=1.54184 \AA$ ) fitted with an area detector and the data extracted using the CrysAlis package. ${ }^{25}$ The structure solutions for all four compounds were solved by direct methods (SIR92) ${ }^{26}$ then refined using the CRYSTALS program package. ${ }^{27}$ Atomic coordinates, bond lengths and angles, and displacement parameters have been deposited at the Cambridge Crystallographic Data Centre (CCDC nos. 1832710, 1827734, 1827735, 1827736 and 1827737). These data can be obtained free-of-charge via www.ccdc.cam.ac.uk/data_request/cif, by emailing data_request@ccdc.cam.ac.uk, or by contacting The Cambridge Crystallographic Data Centre, 12 Union Road, Cambridge CB2 1EZ, UK; fax: +44 1223336033.

\section{Supplementary Material}

The anisotropic displacement ellipsoid plot derived from the single-crystal X-ray structures of compounds 15/32, 28, 34, 35 and 37 together with the ${ }^{1} \mathrm{H}$ and/or ${ }^{13} \mathrm{C}$ NMR spectra of compounds 14-20, 25-40, 43-59, 61 and 64 are available on the Journal's website.

\section{Author Information}

\section{Corresponding Author}

*E-mail: Martin.Banwell@anu.edu.au

ORCID $^{\text {ID }}$

Martin G. Banwell: 0000-0002-0582-475X

\section{Notes}

The authors declare no competing financial interest.

\section{Acknowledgements}

We thank the Research School of Chemistry and Institute of Advanced Studies at the Australian National University for support. The receipt of an ARC Linkage Grant that underpinned this work is gratefully acknowledged, as is the provision of an APA(I) to EC. 


\section{References and Footnotes}

1. For a very useful introduction to this topic, set in an historical context, see: K. C. Nicolaou and S. Rigol, J. Antibiot., 2018, 71, 153.

2. For recent reviews see: (a) R. Shang, J. Liang, Y. Yi and J. Wang, Molecules, 2015, 20, 16127; (b) J. D. Rudolf, L.-B. Dong and B. Shen, Biochem, Pharmacol., 2017, 133, 139.

3. $\quad$ See, for example, (a) E. Martens and A. L. Demain, J. Antibiot., 2011, 64, 705; (b) L.-B. Dong, J. D. Rudolf and B. Shen, Org. Lett., 2016, 18, 4606 and references cited therein.

4. $\quad$ K. Palanichamy and K. P. Kaliappan, Chem. Asian J., 2010, 5, 668.

5. K. A. B. Austin, M. G. Banwell and A. C. Willis, Org. Lett., 2008, 10, 4465.

6. K. C. Nicolaou, G. S. Trai and D. J. Edmonds, Angew. Chem. Int. Ed., 2008, 47, 1780.

7. For a summary of the ways in which such cis-1,2-dihydrocatechols are produced and have been exploited in our group, see: E. S. Taher, M. G. Banwell, J. N. Buckler, Q. Yan and P. Lan, Chem. Record, 2018, 18, 239.

8. E.-L. Chang, B. D. Schwartz, A. G. Draffan, M. G. Banwell and A. C. Willis, Chem. Asian J., 2015, 10, 427.

9. R. N. Muhammad, A. G. Draffan, M. G. Banwell and A. C. Willis, Synlett., 2016, 27, 61 .

10. Both the $R$ - and the $S$-enantiomeric forms of compound $\mathbf{1 7}$ have been reported: (a) G. Sabitha, G. Chandrashekhar, J. S. Yadav, K. Rachineni and B. Jagadeesh, RSC Adv., 2102, 2, 10157; (b) T. Mahapatra, T. Das and S. Nanda, Bull. Chem. Soc. Jpn, 2011, 84, 511.

11. E. J. Corey and M. Chaykovsky, J. Am. Chem. Soc., 1965, 87, 1353.

12. J.-L. Luche, J. Am. Chem. Soc., 1978, 100, 2226.

13. J. Furukawa, N. Kawabata and J. Nishimura, Tetrahedron, 1968, 24, 53.

14. R. E. Ireland and L. Liu, J. Org. Chem., 1993, 58, 2899.

15. For recent applications of this process, see: X. Ma, N. Anderson, L. V. White, S. Bae, W. Raverty, A. C. Willis and M. G. Banwell, Aust. J. Chem., 2015, 68, 593. 
16. K. C. Nicolaou, D. L. F. Gray, T. Montagnon and S. T. Harrison, Angew. Chem. Int. Ed., 2002, 41, 996.

17. Z. Ma and J. M. Bobbitt, J. Org. Chem., 1991, 56, 6110.

18. T. Inokuchi, H. Kawafuchi and S. Torii, Chem. Lett., 1992, 1895.

19. G. Y. C. Leung, H. Li, Q.-Y. Toh, A. M.-Y. Ng, R. J. Sum, J. E. Bandow and D. Y.-K. Chen, Eur. J. Org. Chem., 2011, 183.

20. L. A. Carpino, A. El-Faham, C. A. Minor and F. Albericio, J. Chem. Soc., Chem. Commun, 1994, 2, 201.

21. W. J. Middleton, Org. Synth. 1986, 64, 221.

22. W. C. Still, M. Kahn and A. Mitra, J. Org. Chem., 1978, 43, 2923

23. A. B. Pangaborn, M. A. Giardello, R. H. Grubbs, R. K. Rosen and F. J. Timmers, Organometallics, 1996, 15, 1518.

24. L. F. Fieser and M. Fieser, Reagents for Organic Synthesis, John Wiley and Sons, New York, 1967, page 1276.

25. CrysAlis PRO Version 1.171.37.35h (release 09-02-2015 CrysAlis171.NET) (compiled Feb 9 2015,16:26:32) Agilent Technologies: Oxfordshire, UK.

26. SIR92. A. Altomare, G. Cascarano, C. Giacovazzo, A. Guagliardi, M. C. Burla, G. Polidori, M. Camalli, J. Appl. Crystallogr. 1994, 27, 435.

27. P. W. Betteridge, J. R. Carruthers, R. I. Cooper, K. Prout, D. J. Watkin, J. Appl. Crystallogr. 2003, 36, 1487. 